\title{
Cafeicultura: Recuperação de áreas degradadas e uso de práticas agroecológicas no manejo do café em região de montanhas
}

Cleber Cássio Ferreira, Mário Euclides Pechara da Costa Jaeggi, Thiago Blunck Rezende Moreira, Maurício Novaes Souza, Dayvson Dandi Rodrigues, Ronald Assis Fonseca, Fábio Gomes Zampieri, Credigar Gonçalves Moreira, Alex Justino Zacarias, Isabel Inácio de Moraes Souza

https://doi.org/10.4322/mp.978-65-991393-6-9.c3

\section{Resumo}

A cultura cafeeira no Brasil é extraordinariamente disseminada: o Brasil é líder no ranking produtivo mundial como produtor, com 2.25 milhões de hectares de área plantada, e produção de mais de 60 milhões de sacas (Conab), além de sermos o segundo maior consumidor de café do mundo, perdendo apenas para os Estados Unidos. Em produção interna, Minas Gerais é o primeiro, e o Espírito Santo é o segundo maior produtor de café do Brasil: o primeiro em conilon e o terceiro na produção do café arábica. De forma geral, o café é produzido em regiões de relevo movimentado: o arábica, nas regiões com temperaturas baixas e cadeias de montanhas desses estados, ocupando em torno de 150 mil hectares no ES. No entanto, há muitas áreas que sofrem com o manejo convencional que estimulou o surgimento de processos impactantes, que promoveram o aparecimento de inúmeras áreas degradadas, tornando preocupante, o futuro sustentável da produção. Dessa forma, urge o estabelecimento de medidas de manejo e procedimentos de recuperação, que podem ser tomadas para evitar ainda mais processos degradativos e proteger áreas de risco ou em uso. Essas técnicas são elaboradas por intermédio do PRAD - Plano de Recuperação de Áreas Degradadas, que incluem técnicas de proteção, recuperação, conservação, manejo, entre outros. Assim, o objetivo deste capítulo é a elaboração e junção de técnicas de recuperação de áreas degradadas aplicadas às áreas de cultivo do cafeeiro em região de montanhas, visando evitar a erosão do solo por meio da restauração da estrutura do solo e da dinâmica do ecossistema com suas características bióticas e abióticas, trazendo benefício ao meio ambiente e à condição socioeconômica da propriedade cafeeira.

Palavras-chave: Áreas Degradadas, cafeicultura de montanha, manejo agroecológico, práticas culturais conservacionistas, recuperação ambiental.

\section{Introdução}

Os sistemas agrícolas convencionais se caracterizam por atividades de uso intenso e revolvimento do solo. Utilizam grandes quantidades de fertilizantes de rápida solubilidade e agrotóxicos, o que resulta na redução da quantidade de C orgânico no solo. Em consequência do sistema de manejo inadequado e do uso contínuo do solo, o processo de degradação do ambiente se intensifica. 
Dessa forma, a agricultura tem sido considerada uma das principais causas e, ao mesmo tempo, uma das vítimas dos problemas ambientais da atualidade. Segundo Primavesi (2006), no sistema de manejo convencional, o solo é considerado somente como suporte físico para as plantas. Esse sistema foi disseminado em todos os continentes e se baseia no emprego de pacotes químicos destinados a nutrir as plantas cultivadas. A verdade, porém, é que estes sistemas interferem na biota do solo, desequilibrando o agroecossistema. Estudos relacionados aos processos do solo, assim como sua qualidade, são essenciais tendo em vista que a sustentabilidade do uso dos recursos naturais, para que assim não ocorra a sua degradação.

Considerando a "Cafeicultura" capixaba, há de se considerar que é a principal atividade econômica de $80 \%$ dos municípios. No Espírito Santo o café arábica (Coffea arabica L.) é cultivado predominantemente em áreas declivosas (600-1.200 m), em 26.313 propriedades rurais, envolvendo 53 mil famílias, em uma área de 150 mil ha e produção média anual de três (3) milhões de sacas. Embora haja disponibilidade de tecnologias, a sustentabilidade dessa cafeicultura enfrenta diversos desafios, tais como: a) a redução de custos; b) a diversificação e aumento da renda; c) a melhoria da qualidade de vida; d) a conservação dos solos; e e) a melhoria da qualidade do café (TRISTÃO et al., 2019).

Segundo esses mesmos autores, as novas tecnologias disponibilizadas, como cultivares mais bem adaptadas às condições de cultivo, colheita semimecanizada, implementos mais adaptados às condições declivosas, microterraceamento das lavouras, manejo com cobertura do solo, podas adequadas, adubações químicas e orgânicas equilibradas, têm permitido elevar a produtividade e os patamares de sustentabilidade.

Além disso, o adequado ponto de colheita, tecnologias pós-colheita para diferentes altitudes, como formas e tempos diferentes para fermentação, sistema protegido para secagem dos grãos e técnicas para manejo pós-colheita preservam o potencial global das diferentes qualidades de bebida, ressaltando em sabores/aromas diferenciados. Capacitações contínuas em boas práticas agrícolas (BPA) e pós-colheita, treinamentos em classificação/degustação/ponto de torra de café para torrado/moído e espresso, permitem melhor comercialização de diferentes cafés para mercados nacionais/internacionais, redes varejistas ou diretamente para consumidores, melhorando o padrão econômico da sustentabilidade, em seus aspectos socioeconômicos (TRISTÃO et al., 2019).

Contudo, para esses mesmos autores, atingir patamares superiores de sustentabilidade dependente da aceitação global pelos diferentes atores envolvidos na cadeia produtiva e no mercado consumidor. Somente com a conscientização das partes envolvidas e remuneração adequada de cafés superiores, as famílias rurais continuarão estimuladas para permanecerem nas propriedades, produzindo café de alta qualidade, preservando o meio ambiente e gerando emprego e renda no meio rural nas montanhas do Espírito Santo. Há de se considerar, ainda, a questão sucessória.

No entanto, o Espírito Santo possui em torno de 393 mil hectares de área agrícola degradada, o que corresponde a aproximadamente $17 \%$ das terras agrícolas do estado (CEDAGRO, 2012). Isso representa um enorme potencial em termos de transformação de áreas improdutivas e degradadas em fontes de geração de renda, empregos diretos e indiretos, e ainda conservação dos recursos naturais em especial solo e água. Minas Gerais, o maior produtor brasileiro, também apresenta um percentual bastante elevado de terras degradadas. 
No Brasil, uma das principais fontes de emissão de dióxido de carbono $\left(\mathrm{CO}_{2}\right)$ e outros "Gases de Efeito Estufa" (GEE) é a mudança de uso do solo: inicia-se com a derrubada das florestas para uso agropecuário convencional (BRASIL, 2010). Com o intuito de reduzir as emissões de GEE, alguns programas foram criados pelo governo federal, dentre eles pode-se destacar o programa Agricultura de Baixo Carbono (ABC), que tem como principal objetivo incentivar o desenvolvimento de práticas sustentáveis, associados com o aumento de renda dos produtores rurais, e especialmente para a difusão das seguintes tecnologias: integração lavoura-pecuária-floresta (ILPF); sistemas agroflorestais (SAFs); e recuperação de pastagens e áreas degradadas (MARTINS; SOUZA, 2013; TORRES et al., 2014).

Merece destaque os SAFs: o Sistema Agroflorestal é um sistema de manejo de recursos naturais, dinâmico e baseado em princípios ecológicos, e vem se destacando entre as técnicas de manejo utilizadas pela agricultura, inclusive na cafeicultura (Figura 1). Faz-se por intermédio da integração entre produção agrícola, florestal e, ou, animal, que diversifica e mantem um sistema de produção sustentável, e que utiliza técnicas conservacionistas do uso do solo e da água. Além disso, suprem os interesses sociais, econômicos e ambientais, promovendo benefícios a todos estes seguimentos (MACAULAY Land Use Research Institute, 2020; SALGADO, 2006; SOUZA et al., 2020).

A Recuperação de Áreas Degradadas pela atividade da cafeicultura utilizando os SAFs está baseada nos princípios da agroecologia: além de melhorar as condições do solo e do estoque de água do solo, da microbiota e do estoque de matéria orgânica, estabelecem relações positivas entre seus componentes, o que viabiliza a produção integrada em áreas degradadas que se encontram improdutivas (FRANCO, 2000; SOUZA et al., 2020).

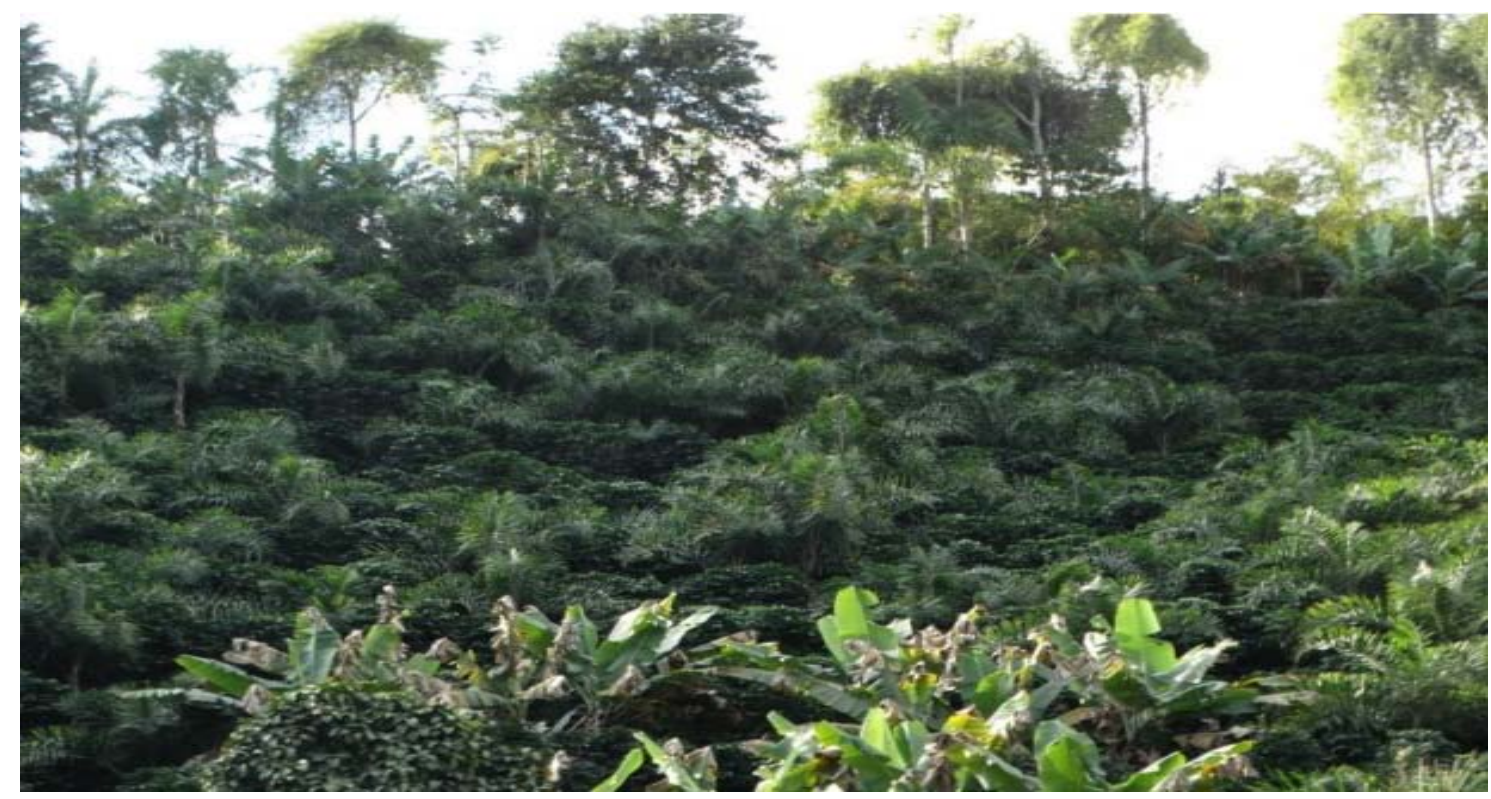

Figura 1. Lavoura de café em condições de sombreamento. Fonte: SOUZA et al., 2020.

No Estado do Espírito Santo, a cafeicultura se destaca por ser a principal atividade agrícola do estado, abrangendo todas as regiões de forma bastante diversificada. A maioria dos produtores capixabas está situada em pequenas propriedades rurais, são de base familiar e, em sua maioria, suas lavouras estão alocadas em áreas de relevo 
acidentado. A cafeicultura abrange uma área de aproximadamente 435 mil hectares no estado e corresponde cerca de 35\% do Produto Interno Bruto (PIB) Agrícola capixaba. As principais espécies cultivadas são o Coffea arabica (arábica), nas regiões de menor temperatura e maior altitude; e o Coffea canephora (conilon), nas regiões de maior temperatura e menor altitude (INCAPER, 2020).

A cafeicultura representa a principal fonte de renda dos pequenos agricultores capixabas (Figura 2). No entanto, é importante incentivar e fomentar a diversificação da produção rural. Essa é uma estratégia utilizada para minimizar as incertezas oriundas do momento de comercialização da produção. Além disso, reduz os riscos de se produzir uma única cultura e sofrer altos impactos de fatores externos na produção, como clima, economia, pragas e doenças. A diversificação da produção ainda traz benefícios ambientais, ganhos econômicos e manutenção da agricultura familiar (SOUZA JUNIOR, 2019).

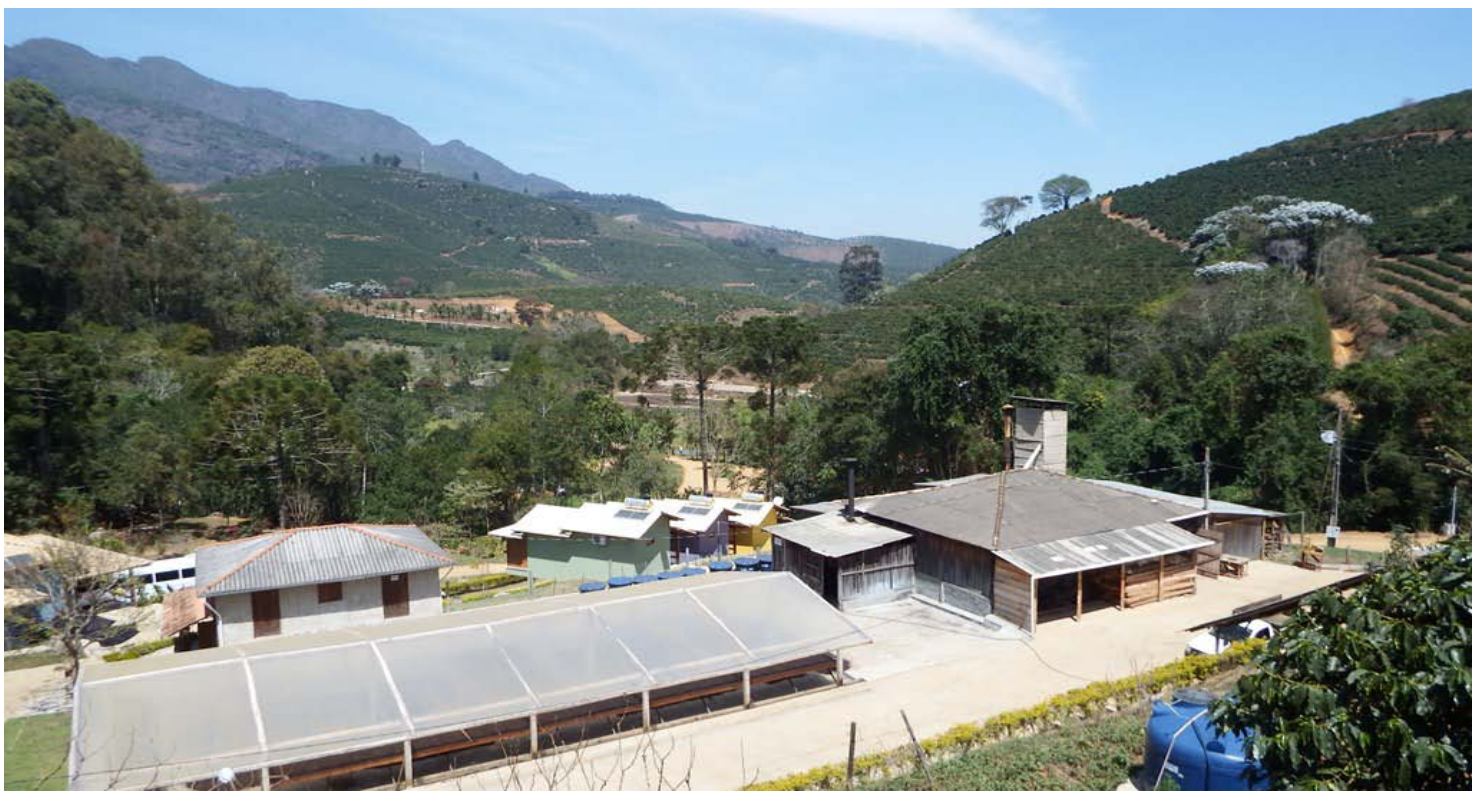

Figura 2. Sítio Santa Rita, Pedra Menina, município de Espera Feliz.

O segmento de café especial representa cerca de $12 \%$ do mercado internacional de cafés (Figura 3). O valor agregado a este produto é, em média, 30 a $40 \%$ maior do que os cafés convencionais. Para pequenos produtores rurais isso significa uma ótima oportunidade de aumentar a capitação de renda em suas propriedades (SILVEIRA, 2016).

Luiz Ricardo Bozzi Pimenta de Sousa, jovem de apenas 20 anos, foi o grande campeão da "Cup of Excellence 2020". Esse evento é realizado pela Associação Brasileira de Cafés Especiais (BSCA), em parceria com a Agência Brasileira de Promoção de Exportações e Investimentos (Apex-Brasil) e a Alliance for Coffee Excellence (ACE). Os 30 vencedores poderão comercializar seus cafés por preços superiores ao mercado convencional. Segundo os organizadores e o referido produtor, espera que a conquista inspire jovens e agricultores familiares a seguirem o caminho da qualificação, e pontua (CAFEPOINT, 2020):

"café especial é um caminho sem volta, com rentabilidade muito grande. E não é só questão de preço, mas também de qualidade de vida, pois quando se trata o solo com mais 
carinho, quando há mais respeito com a natureza, nos tornamos seres humanos melhores e passamos a ter melhores produções. Tudo isso foi o que aprendi no Ifes e na BSCA, que foi um divisor de águas para a gente sempre estar motivado a investir mais em qualidade e no bem estar das lavouras e no nosso bem estar, o que é refletido na qualidade final".

E complementa:

"Fiz curso técnico em agropecuária, o que despertou minha paixão por plantas, cultivares e solo. $\mathrm{Na}$ escola, seguimos um princípio agricultura orgânica, sustentabilidade, agroecologia. Isso fez com que eu me apaixonasse pelo setor e quisesse trazer algo diferente e melhor para dentro da propriedade. Foi através desse entusiasmo que começamos o desenvolvimento dos nossos cafés".

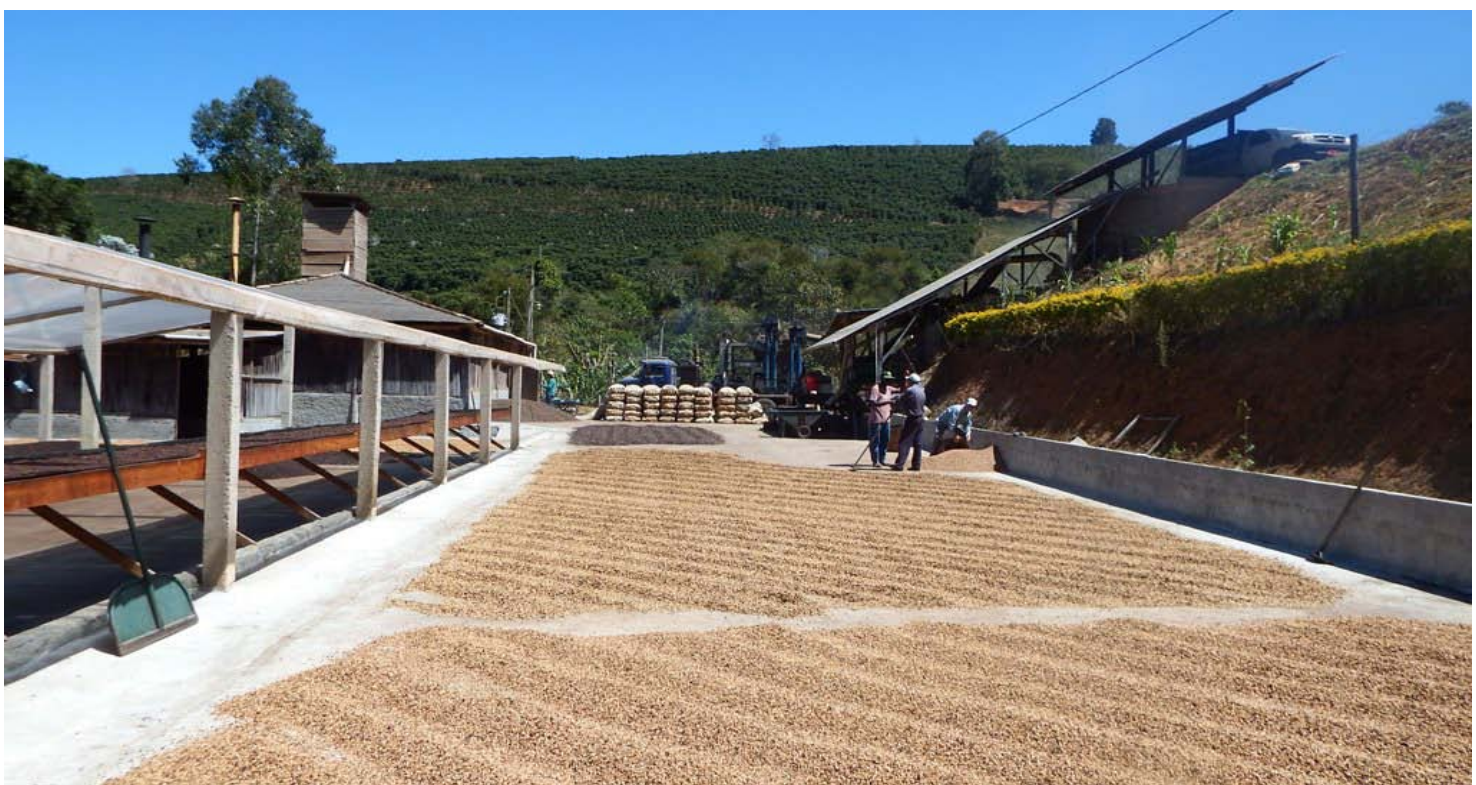

Figura 3. Produção de cafés especiais no Sítio Santa Rita, Espera Feliz.

Observa-se que o futuro da cafeicultura está na qualificação e modernização, e na busca por novos nichos de mercado, onde a sustentabilidade ambiental é uma das prioridades. Estudos comandados por instituições nacionais e internacionais apontam que o futuro da agricultura será determinado pela maneira em que os produtores administram a diversificação da produção agrícola e na sua condução (SILVA, 2019; SOUZA et al., 2020). A diversidade na agricultura possibilita ao agricultor obter renda de outros recursos naturais, especialmente dos recursos florestais madeireiros e não madeireiros, como o plantio de frutíferas.

Entretanto, há de se considerar, que em todas as regiões agrícolas do Estado do Espírito Santo e nas regiões produtoras de café de montanha (Minas Gerais, Rio de Janeiro e São Paulo), existem problemas visíveis de degradação do solo. A situação é mais grave nas bacias hidrográficas da região noroeste e da região sul capixaba de baixa altitude (CEDAGRO, 2012). A maior parte dessas áreas é de pastagens mal manejadas e que se encontra em condições de relevo acidentado: condição mais propícia à erosão, o que leva a baixa produtividade e à degradação da qualidade do solo (SEAG, 2008). 
Assim, a cafeicultura que é a cultura mais importante economicamente no Espírito Santo, tornou-se a grande vilã na degradação do solo, pela forma de se conduzir as plantações: práticas de queimadas, uso irracional de agrotóxicos e manejo dos solos sem cobertura vegetacional. A degradação do solo tem início quando se interfere na sua cobertura natural, eliminando-a simplesmente, ou substituindo-a por uma cultura malconduzida (Figura 4).

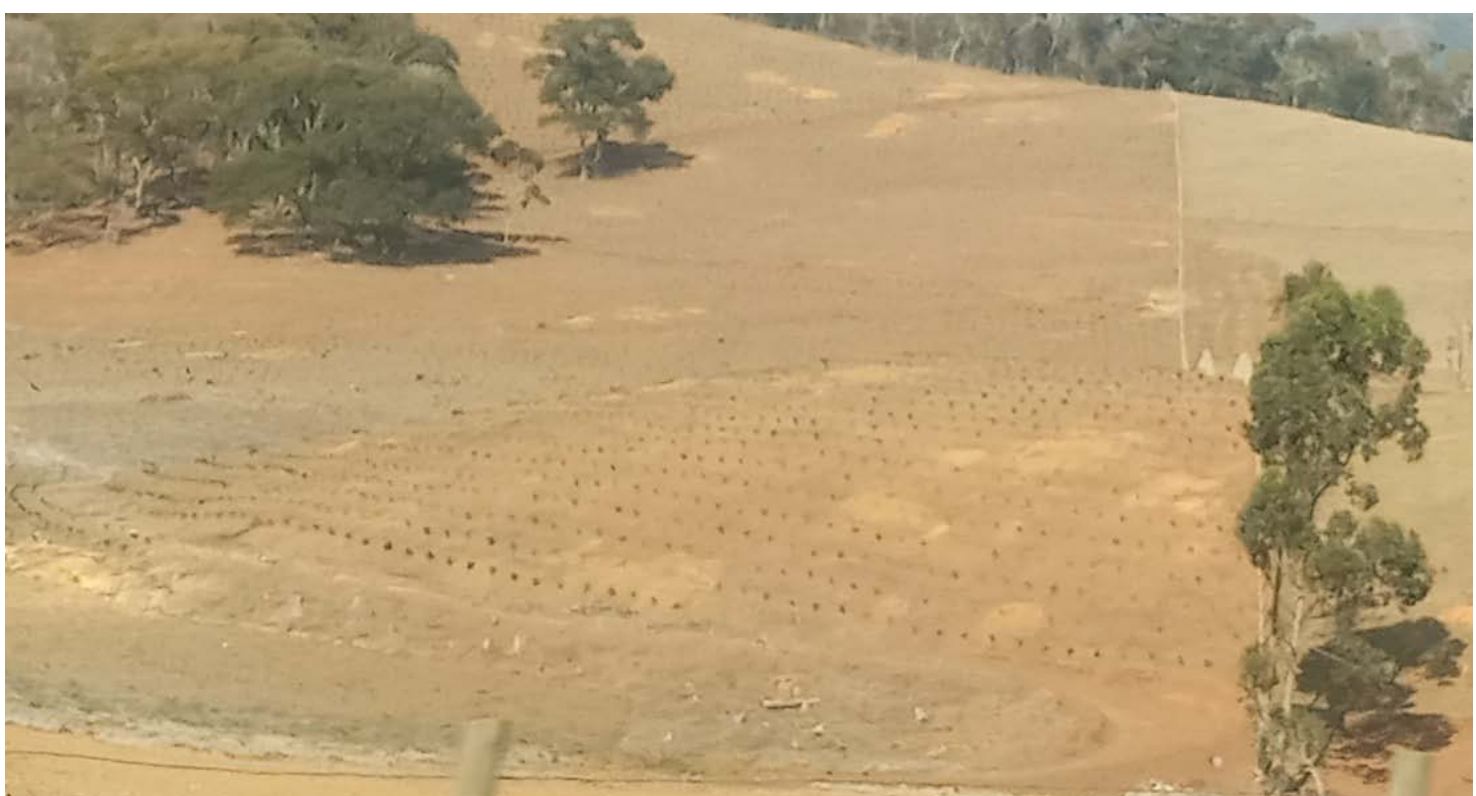

Figura 4. Área com a cultura do café na região do Caparaó capixaba sem cobertura vegetacional e nenhuma prática conservacionista de solo.

O solo, desprovido de cobertura vegetal e da ação fixadora das raízes, exposto ao impacto direto da chuva ou do vento, sofre desagregação ("splash") e remoção de suas partículas nas enxurradas. Este efeito é complementado pelo escoamento superficial das águas, ou pela abrasão das partículas transportadas pelo vento comum na medida em que o solo fica compactado (EMBRAPA, 2011; SOUZA, 2018).

Para a conservação do solo e da água, por meio do manejo, recomendam-se práticas conservacionistas fundamentadas em três princípios básicos: a) aumento da cobertura vegetal (reduz a desagregação e transporte de partículas do solo); b) infiltração de água no solo (reduz o escoamento superficial e as perdas de água e solo); e c) rugosidade do terreno (reduz a velocidade e o volume do escoamento superficial e aprisiona os sedimentos da erosão) (Figura 5) (SOUZA, 2018).

O uso de práticas agrícolas e de procedimentos de conservação do solo e da água é importante para a recuperação de áreas degradadas, tais como: análise de solo, rotação de culturas, adubação verde, terraceamentos, caixas secas e quebra-ventos. Todas estas técnicas, vegetativas e mecânicas, associadas, buscam conservar e recuperar solos degradados pela ação do homem; entretanto, a escolha de sistemas de produção ou de práticas conservacionistas de solo e água deve ser feita em função dos aspectos ambientais e socioeconômicos de cada propriedade e região. 


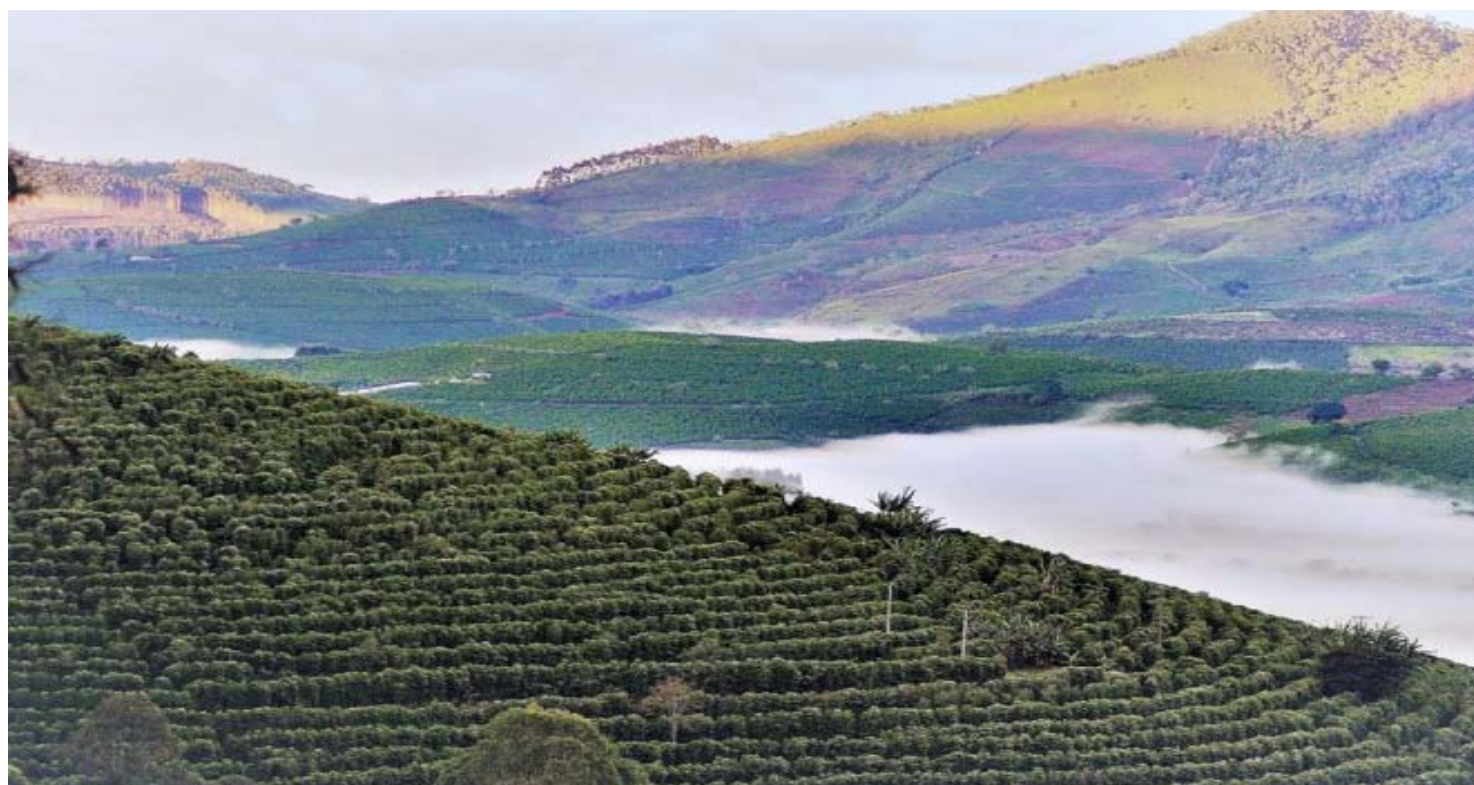

Figura 5. Café nas regiões das Montanhas do Espírito Santo. Fonte: CAFEICULTURA DO CAPARAÓ, 2017.

O objetivo deste capítulo é apresentar um plano de manejo para a atividade de cafeicultura, por meio de técnicas de planejamento e de manejo; bem como apresentar procedimentos de recuperação de áreas degradadas por lavouras cafeeiras em áreas de montanha com relevo movimentado.

Para tal fim, utilizou-se a pesquisa "Exploratória", com a finalidade de proporcionar informações sobre o assunto, evidenciando-o; e a pesquisa "Observatória", permitindo uma descrição detalhada de experiências de sucesso já vivenciadas.

Há de se considerar, entretanto, que não existe um modelo único para todas as propriedades: há de se analisar as particularidades e peculiaridades de cada unidade produtiva, por exemplo, as condições edafoclimáticas locais.

\section{Avaliação dos estádios pré e pós-degradação}

Existem várias experiências de sucesso em programas de recuperação. Entretanto, para fazer o monitoramento dos procedimentos de recuperação é fundamental acompanhar as alterações que se processarão no agroecossistema. Considerando o componente "Solo", uma das formas de avaliar as suas perdas por processos erosivos em áreas degradadas ou recuperadas, para a verificação do estádio da sua recuperação, é possível usar como estratégia a comparação destas áreas com paisagens naturais localizadas na proximidade. Elas representam a memória de uma dada região (SOUZA, 2018).

Tratando-se do processo de implantação de uma dada lavoura, os danos ambientais causados inicialmente são a supressão da vegetação, com o corte raso e o posterior plantio de café no local. Com o uso do solo sem o devido planejamento, sem manejo adequado ou o não uso de práticas conservacionistas, ocorre o esgotamento dos nutrientes e a compactação do solo, seguindo-se o processo de erosão (Figura 6).

Essa estimativa das condições atuais de uma dada lavoura em estádio de degradação pode utilizar como estratégia a comparação destas áreas com paisagens naturais localizadas na proximidade: elas representam a memória dessa região! Deve ser feita 
analisando-se as diversas características do local, incluindo clima, topografia, geologia, cobertura vegetacional, uso e manejo do solo. Servirá também de base para monitoramento e comparações futuras do local. Caso haja, por exemplo, a evidência de que processos erosivos persistem, evidenciam a existência de problemas hidrológicos no local (SOUZA, 2015; 2018).

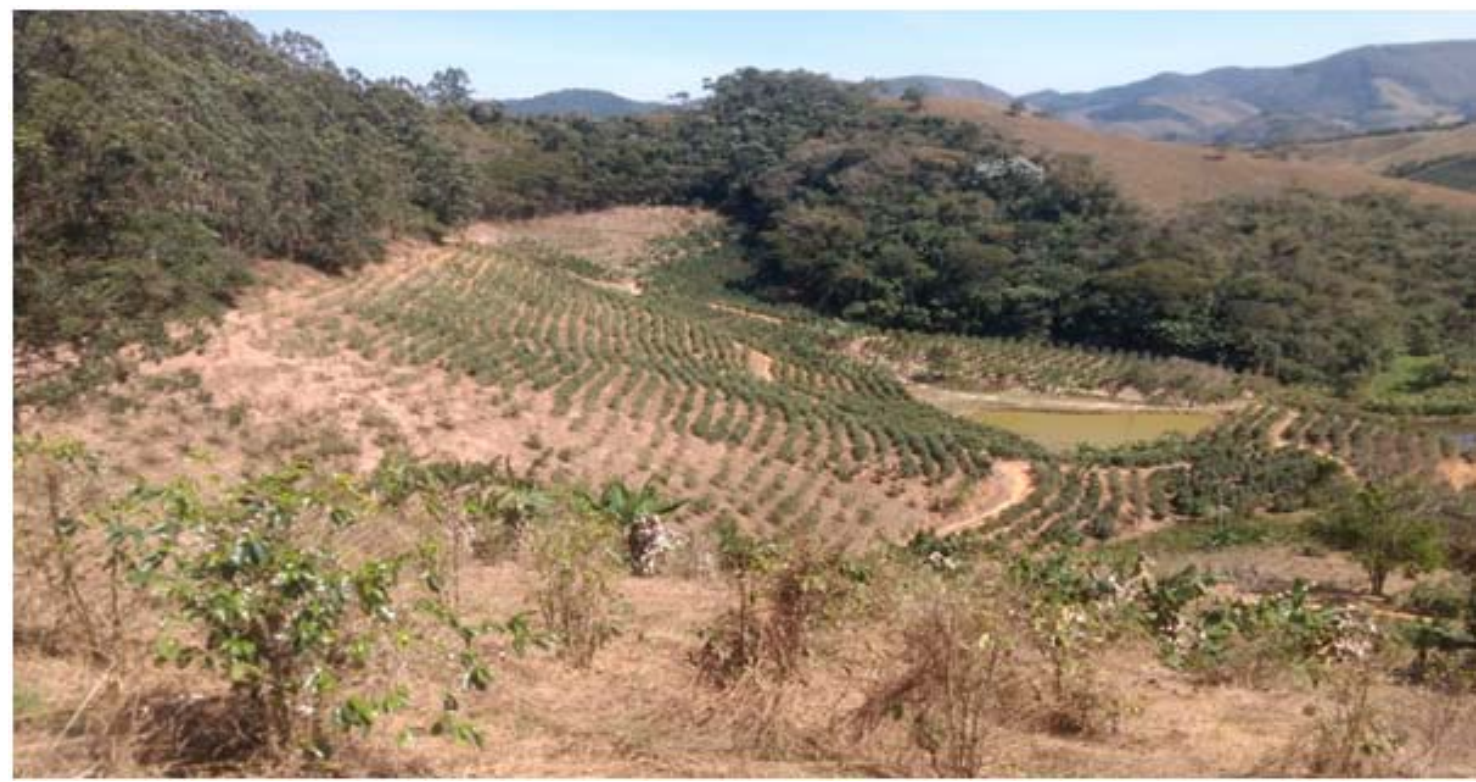

Figura 6. Atividade cafeeira: área degradada e ausência de práticas conservacionistas.

O fato é que a cobertura vegetacional, a diversidade de espécies e a produtividade da área alterada são habitualmente comparadas com as áreas não perturbadas; ou seja, é uma estratégia que utiliza como abordagem uma "área de referência". Entretanto, essa estratégia poderá ser problemática, pois:

a) exige réplicas do ecossistema pré-perturbação; e

b) envolve comparações entre comunidades de plantas nos seus diversos estádios de desenvolvimento e da comunidade original desse solo com distúrbios.

Uma alternativa é a "abordagem utilitária", que avalia se a capacidade do solo perturbado ou degradado caso corretamente utilizado, bem manejado e com o uso de práticas conservacionistas, poderá sustentar a capacidade pretendia de uso do solo.

Por exemplo, se o uso futuro do solo escolhido for para a atividade cafeicultura, solos recuperados deverão ter produtividade suficiente para garantir ganhos financeiros apropriados para a região, sem efeitos prejudiciais ao ecossistema.

Entretanto, o procedimento correto para o sucesso da recuperação, mais seguro e científico, exige a elaboração de cenários pré e pós-degradação, onde serão estabelecidos os objetivos do processo de recuperação; além do detalhamento minucioso do cenário atual (Diagnóstico ambiental, que em uma área primária, equivalerá ao cenário pré-degradação - poderá ser estabelecido a partir dos Estudos de Impactos Ambientais e do seu Relatório (EIA/RIMA)). 
Ou seja, caberá sempre considerar que poderão ocorrer duas (2) situações:

- A área está em sua condição natural, preservada, e será explorada por uma dada atividade; e

- A área já se encontra degradada e será recuperada para nova destinação: atividade comercial, com a introdução de um novo cultivo de café, ou voltada para fins de conservação ou preservação ambiental.

Na primeira condição, será elaborado o Cenário pré-degradação, por meio de um EIA/RIMA, onde será realizado o Diagnóstico Ambiental da área.

Na segunda condição, a área já não tem suas condições originais e encontra-se degradada. Ou seja: na execução do EIA/RIMA, o diagnóstico ambiental presente considerará as condições atuais, sendo necessária uma vasta pesquisa para se elaborar o Cenário pré-degradação: uma alternativa é buscar nas proximidades áreas que apresentem as mesmas características desse local degradado, como relevo, altitude e face de exposição ao sol, observando a vegetação e os variados componentes desse ecossistema, para que se possam pressupor quais eram suas características originais.

Detalhes pormenorizados podem ser vistos no Capítulo 1, Item 4.3., do presente livro.

\section{Plano de recuperação de áreas degradadas (PRAD)}

O processo de recuperação ambiental é complexo, requerendo tempo, recursos (dinheiro, mão de obra e tecnologia) e conhecimento dos diversos fatores relacionados à área a ser recuperada, tais como as características do solo, da água, da fauna, da flora e as modificações inerentes ao processo que ocasionam (ou ocasionarão) o distúrbio. O PRAD deve ter inicialmente seus objetivos bem definidos, ajustando variáveis, tais como: as necessidades legais, o desejo do proprietário do terreno, os aspectos sociais e econômicos. Nunca há de se esquecer de que o objetivo principal é promover a recuperação ambiental do agroecossistema degradado (SOUZA, 2018; ZACARIAS; SOUZA, 2019).

O planejamento inicial prevê a necessidade da confecção de um roteiro que busque a solução rápida, eficiente e econômica para se recuperar as áreas degradadas: faz-se necessário conhecer o passado, analisar o presente e planejar o futuro das áreas a serem reabilitadas. O planejamento deve ser com uma visão de longo prazo. O processo de planejamento deve ser realizado, projetando-se em longo prazo e contemplando sempre uma visão global do problema. Os "pacotes" e "receitas" generalistas não funcionam no caso de recuperação: cada situação específica deve receber um tratamento correspondente. As etapas que serão apresentadas compõem apenas um roteiro simples e básico, que pode ser adaptado para cada caso específico.

Uma das etapas mais importantes a ser considerada é o diagnóstico ambiental, realizado por meio dos Estudos de Impactos Ambientais (EIA), que permitem o conhecimento da amplitude dos problemas ambientais, sociais e econômicos envolvidos no processo de estabelecimento e condução da atividade cafeeira. A partir desse levantamento, serão definidos os procedimentos de recuperação ambiental da área e elaborado o seu respectivo PRAD. O diagnóstico prévio de aspectos ambientais (biológicos e socioeconômicos) permite que se estabeleçam o prognóstico da área, por intermédio de metas e cronograma de execução para a recuperação ambiental, 
dando mais consistência ao PRAD e a seu processo de implantação (ZACARIAS; SOUZA, 2019).

O fato é que um sistema deve favorecer o equilíbrio e a harmonia com a natureza por assemelhar-se ao processo natural de sucessão ecológica e promover metodologias/ferramentas que se enquadre a cada modelo proporcionando manejo e conservação do solo. As tecnologias e práticas conservacionistas utilizadas devem restaurar a harmonia do sistema, ser eficiente e economicamente rentável para o produtor rural, podendo ter a finalidade de melhorar a qualidade do solo (ex: cobertura morta ou viva, compostagem laminar, compostagem ou vermicompostagem, biofertilizante, EM, podas do sistema, adubação verde, entre outros, bem como o controle e, ou, resistência de pragas e doenças (alelopatia, controle biológico, caldas, plantas repelentes, entre outros).

As plantas medicinais, por exemplo, possuem princípios ativos que contribuem para repelência e, ou, controle de certos insetos e, ou, doenças. Possuem princípios ativos que contribuem para repelência e, ou, controle de certos insetos e, ou, doenças. Elas podem ser inseridas no SAF como caldas inseticidas, e, ou, cultivadas na bordadura, a fim de atrair ou repelir determinados insetos e, ainda, poderá contribuir para a qualidade do solo. No geral, essas plantas possuem substâncias aromáticas que atuam de forma positiva ou negativa sobre os insetos: buscar compreender este comportamento poderá proporcionar estratégias interessantes no sistema produtivo. A agroecologia já tem por base a preconização da qualidade do solo como sinônimo de uma planta em equilíbrio e sadia, pois quem não ama o seu solo nunca saberá cuidar da saúde biológica, que é a base de sua fertilidade (PRIMAVESI, 2006; SOUZA, 2018; SOUZA et al., 2020).

Ou seja, a intervenção humana nesse ambiente terá que colaborar de forma a gerar um balanço positivo - por isso, a importância de analisar a eficiência de cada tecnologia e as plantas que serão inseridas neste sistema: se atuarão de forma antagônica ou de forma colaborativa.

É importante considerar que a opção pelos procedimentos sugeridos no PRAD mostra zelo e cuidado com o meio ambiente, com o objetivo de obtenção de produção sustentável, além de protegê-lo para as próximas gerações. O PRAD gera inúmeros benefícios, tais como: várias possibilidades de uso do solo, saúde, segurança e produtividade do meio ambiente; além da redução do custo do processo de recuperação. Além disso, o PRAD evita, também, a improdutividade do solo e desmoronamentos de áreas, mantendo a diversidade ambiental e garantindo a qualidade dos recursos naturais renováveis (SOUZA, 2018).

Caso a opção seja por implantar a nova lavoura sob sistema agroflorestal agroecológico (SAFA), no decorrer do processo sucessional, o manejo terá função fundamental para impulsionar o processo de sucessão. Os princípios práticos de poda serão aplicados em plantas com determinadas funções ecológicas dentro do agroecossistema, como as produtoras de biomassa e fixadoras de nitrogênio, e também para manutenção de espécies em determinado estrato (Figura 7). Espera-se, que com o tempo, a deposição da matéria orgânica irá estimular o desenvolvimento da população microbiana. O acúmulo de matéria orgânica irá influenciar a retenção de água, criando um ambiente favorável para a atividade metabólica microbiológica (SOUZA et al., 2020). 


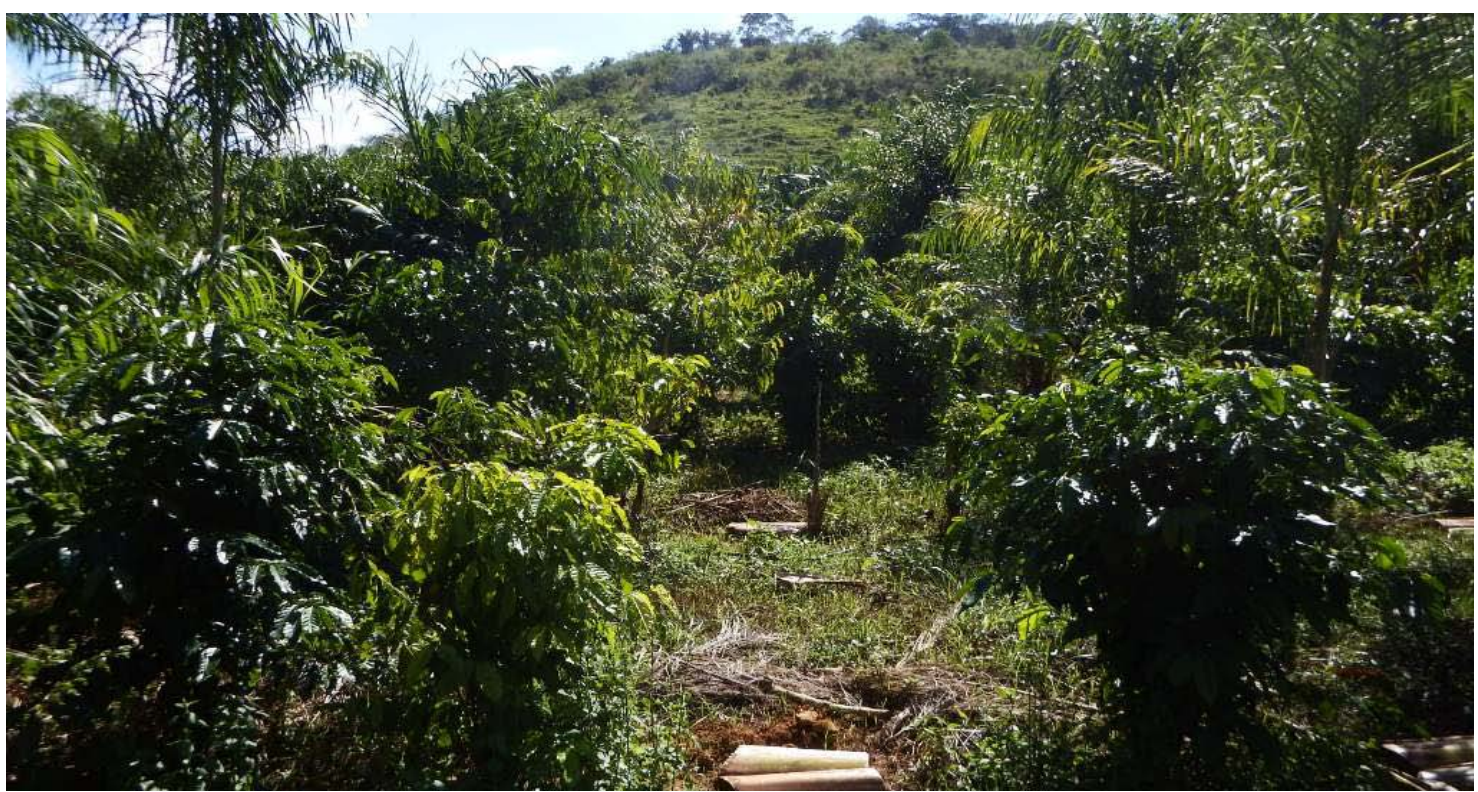

Figura 7. Café em SAFA na Incaper de Pacotuba, Cachoeiro do Itapemirim, ES: podas e produção de matéria orgânica.

De acordo com Melo et al. (2017), a adição de serapilheira pode aumentar cerca de cinco vezes a atividade microbiológica no solo. A alta diversidade vegetal do SAFA poderá ser determinante para o aumento do aporte de nutrientes e serapilheira durante o processo de desenvolvimento do sistema, podendo também formar serapilheiras diferentes, determinadas pela característica fisiológica de cada planta, consequentemente, influenciando na qualidade e na fertilidade do solo.

XIAO et al. (2017) atestam que o aumento da atividade microbiana é decorrente de maior variedade de detritos com diferentes características químicas disponíveis aos microrganismos decompositores, considerando que os grupos de microrganismos variam em suas capacidades bioquímicas de explorar diferentes recursos, essa variedade de detritos permite uma ampla diversidade de microrganismos, acelerando o processo de liberação de nutrientes para o solo. Poderá haver variação nas atividades microbianas relacionadas à sazonalidade.

Dessa forma, os impactos esperados devem conferir a eficácia de um SAFA para não só aumentar a qualidade do solo, mas também recuperar áreas degradadas: visto que tais áreas se encontram, geralmente, em condições de solo compacto e degradado. Contudo, é necessário confirmar a eficiência destes sistemas, para que seja possível melhor estudar a viabilidade dessas alternativas agroecológicas e contribuir para aumentar a rentabilidade do produtor, sua condição socioambiental e as condições de resistência e resiliência do agroecossistema.

Cabe considerar que, no estado do Espírito Santo e em grande parte das zonas produtoras de café de Minas Gerais, é composto por pequenos agricultores familiares de baixa e média renda, e que precisam conciliar a produção agrícola com a manutenção da saúde do ecossistema, para que dessa maneira seja possível reduzir os custos de produção e aumentar a produção de cafés de qualidade.

O planejamento conservacionista é essencial para se obtiverem melhores rendimentos na exploração das culturas, visando obter o máximo rendimento da terra por unidade de área plantada, proporcionando o desenvolvimento socioeconômico do produtor rural e sua família, assim como a conservação dos recursos naturais da propriedade 
agrícola. A caracterização ambiental e o planejamento de uso das terras da propriedade devem ser feitos por técnicos atuantes na área agrícola (EMBRAPA, 2018).

Os procedimentos iniciais exigidos na implantação e, ou, substituição de uma lavoura, bem como as práticas conservacionistas e os procedimentos de recuperação, passo a passo, recomendados no PRAD, serão descritos: Análise e correção do Solo, Plantio em Nível, Terraceamento, Caixa seca, Adubação Verde em Pré-plantio com Leguminosa (Crotalária-Juncea, Margaridão Mexicano e Feijão Guandu), QuebraVento e Manejo do mato de cobertura das entrelinhas, entre outros.

\subsection{Análise de solo}

É a primeira ação a ser tomada pelo produtor. Após a escolha do local onde será implantada a lavoura cafeeira, a divisão da área é feita buscando-se a homogeneidade na composição dos talhões, levando-se em consideração todos os fatores de constituição e formação do solo, como o histórico de utilização e manejo, localização, o relevo, a exposição do solo a fatores edafoclimáticos e as características visíveis do solo (MESQUITA et al., 2016).

A análise de solo é indispensável para o diagnóstico da fertilidade do solo, possibilitando a recomendação da dosagem de adubos e corretivos necessários para obter rendimentos elevados da cultura (DONAGEMA, 2011).

Segundo Mesquita et al. (2016), a amostra de solo para implantação da cultura cafeeira deve suceder-se nas camadas de 0-20 e 20-40 cm na mesma perfuração, a fim de atender a demanda nutricional das plantas a serem inseridas no sistema. Devem seguir os seguintes passos:

\section{Amostra:}

- Pequena porção de 400 a 500 gramas de solo, em que a amostra é composta, buscando homogeneidade do talhão onde serão inseridas as mudas de café;

- Divisão da Área: a área deve ser homogênea - tem alguns aspectos para serem levados em consideração, tais como: tamanho da área, que não deve ultrapassar 10 ha, características do solo, cultura, manejo anterior, face de exposição ao sol, e cor e textura do solo;

- Equipamentos: pode-se usar trado, enxadão, cavadeira, sonda, entre outros.

Após a coleta do solo, identificar as amostras, de acordo com a o talhão extraído com as devidas identificações, constando o nome do produtor, endereço, cultura e o tipo de análise, física, química comum, ou química com micronutrientes. Após o resultado, deve ser encaminhada para o técnico fazer a recomendação de calagem e adubação.

Será usado o calcário, se precisar, para corrigir a acidez; e a fosfatagem, que adiciona fósforo em área total para aumentar o seu teor em solos muito pobres deste elemento.

De acordo com Mesquita et al. (2016), para a técnica de adubação corretiva, recomenda-se a utilização de adubos nitrogenados, fosfatados, potássicos e micronutrientes, e ainda, a associação com adubação verde com leguminosas. A correção da acidez do solo tem efeitos diretos e indiretos sobre a nova cultura, alterando características do solo, tais como: 
- A neutralização do alumínio e do manganês, que podem ser tóxicos para as plantas;

- A elevação das concentrações de cálcio e magnésio;

- A elevação do pH;

- O aumento na disponibilidade de uma série de elementos, por exemplo, o fósforo.

É indispensável a análise de solo para fazer a correção e adubação do solo, fazendo que a adubação seja equilibrada e em quantidades corretas, além de aplicadas na época adequada. Há de se considerar que, caso a lavoura a ser estabelecida seja orgânica ou de produção agroecológica, outros fertilizantes deverão ser utilizados. Nesses sistemas de condução, não é permitido o uso de adubos químicos comerciais.

\subsection{Plantio em nível}

O plantio em curvas de nível, conhecido também como plantio em contorno, consiste na produção ordenada por meio de linhas com diferentes altitudes do terreno. Das medidas de conservação, é considerada essencial e obrigatoriamente aplicável em áreas íngremes. Esta prática promove a conservação do solo contra processos erosivos e contribui com o escoamento da água da chuva: facilita a infiltração no solo, evitando movimentos de massa e promovendo a recarga dos aquíferos, e estimula a microbiota do solo em função da maior umidade (SALEMI, 2009; SOUZA, 2018) (Figura 8).

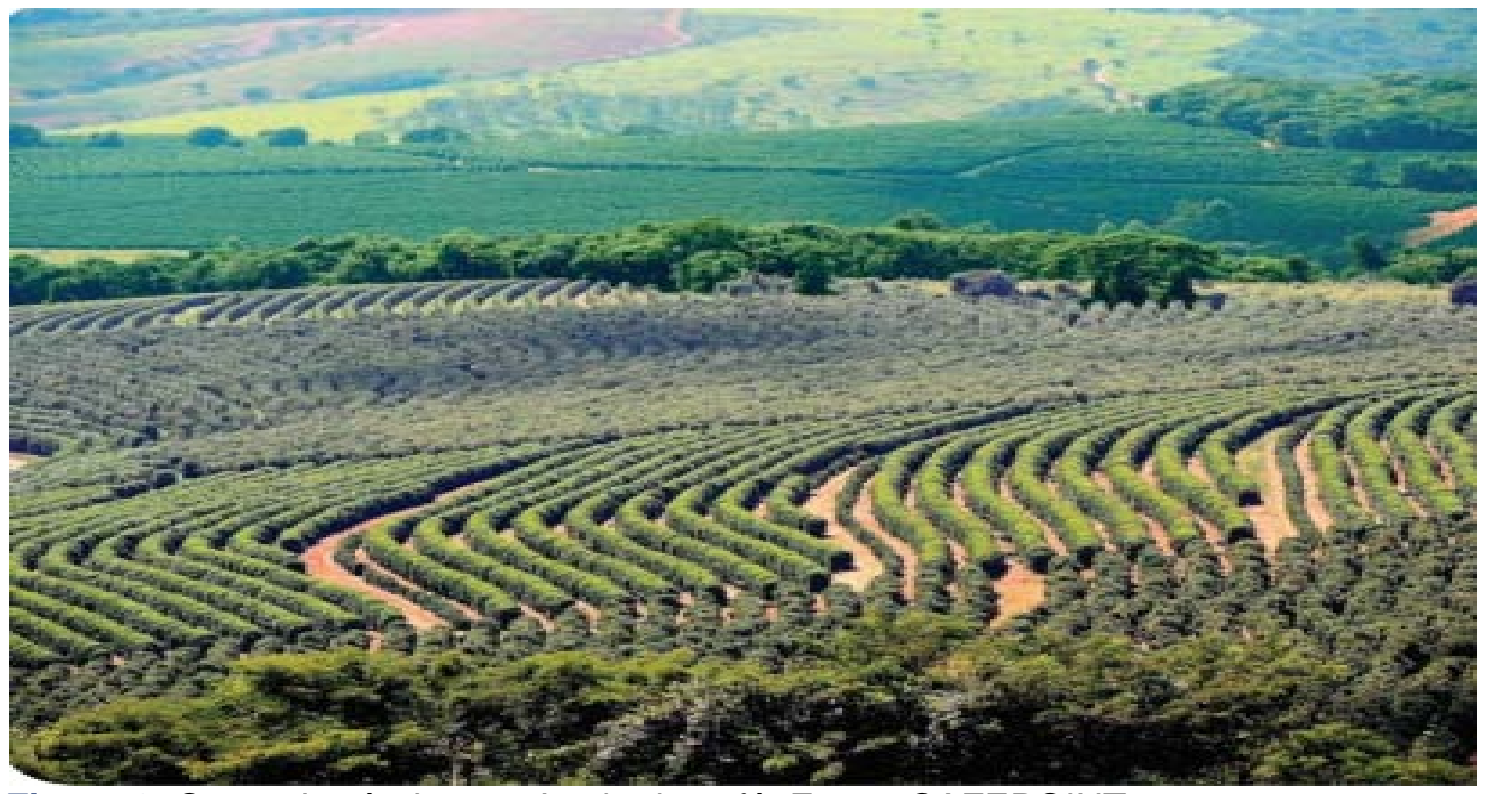

Figura 8. Curva de nível para plantio de café. Fonte: CAFEPOINT, 2020.

A delimitação e definição do número de "terraços" são aplicadas de acordo com a declividade do terreno, podendo ser de base larga ou estreita. As curvas de nível devem ser ordenadas perpendicularmente à inclinação da encosta: assim, ajudam a conservar os nutrientes do solo, que são indispensáveis para o sucesso e sustentabilidade da plantação (GALETI, 1984; SALEMI, 2009) (Figura 9). 


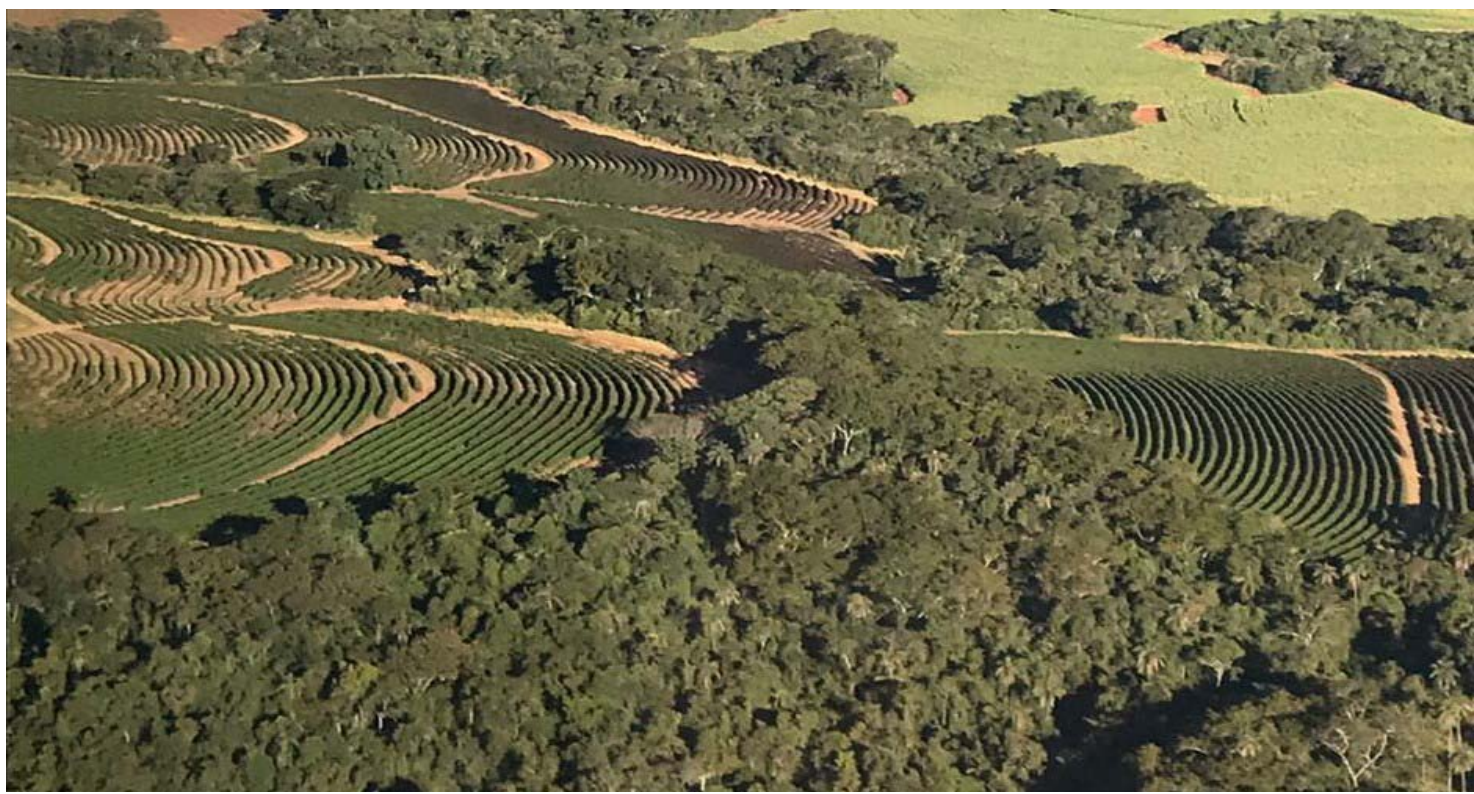

Figura 9. Área com cafezal cultivado com curvas de nível. Fonte: CAFEPOINT, 2020.

Para se estabelecer a curva de nível de forma adequada, têm-se vários equipamentos que podem ser usados, tais como: teodolito, nível ótico, trapézio, mangueira de nível e pé-de-galinha. O uso do trapézio é o mais usado por agricultores familiares, pois sua construção é simples e de fácil manejo.

\section{Materiais necessários:}

- Sarrafo de 2,5 metros;

- Ripa de 1 metro;

- Nível de pedreiro;

- Borracha para segurar no nível no sarrafo; e

- Prego.

Para construir o trapézio é necessário pregar as duas ripas em cada extremidade do sarrafo e fixar o nível de pedreiro na parte superior do sarrafo (Figura 10).
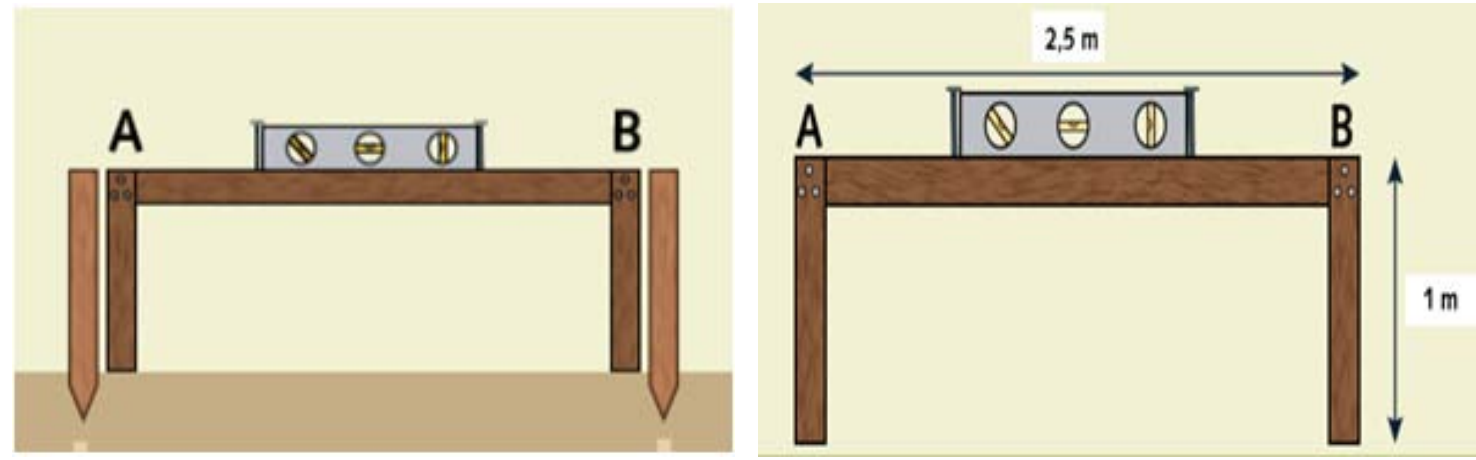

Figura 10. Confecção de um trapézio. Fonte: Mesquita et al., 2016.

\section{Marcação das linhas em nível ou niveladas básicas}

Observa-se na Figura 11 como se constrói a nivelada básica. 


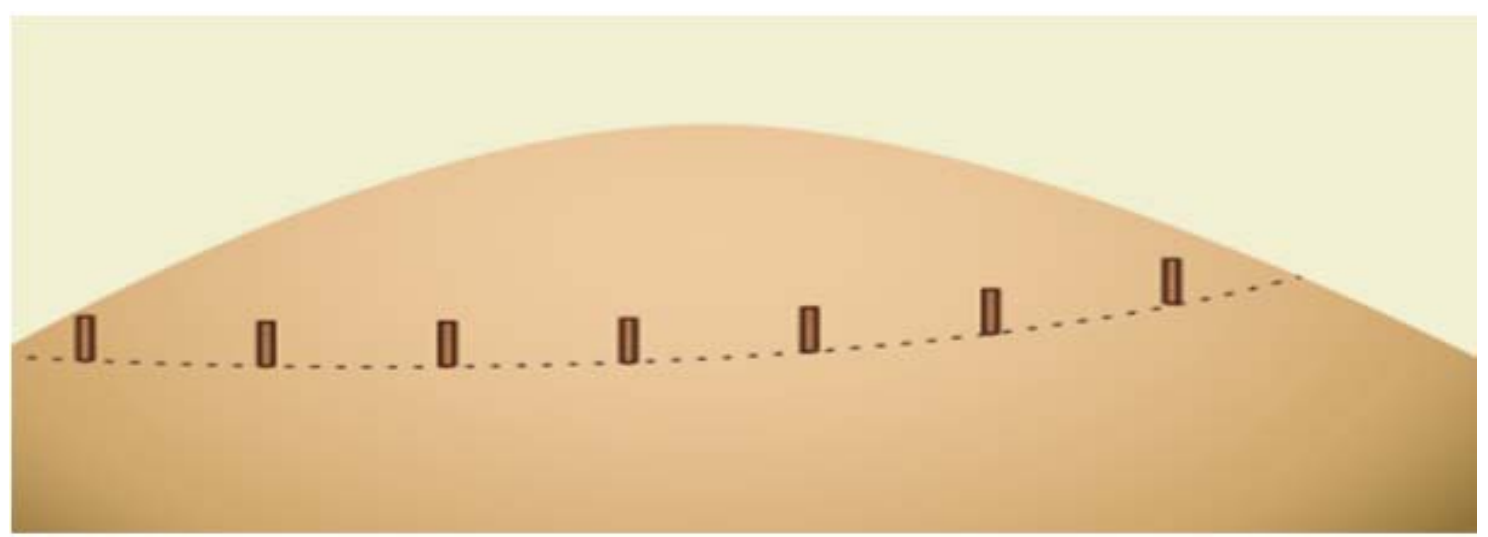

Figura 11. Marcação da nivelada básica. Fonte: Mesquita et al., 2016.

\section{Manejo e procedimentos: passo a passo}

Para facilitar o entendimento, serão descritos todos os passos necessários (FERNANDES; BARRETO; EMÍDIO FILHO, 1999):

1. Fincar uma estaca no chão de onde se quer iniciar a marcação das niveladas: aproximadamente, a $40 \mathrm{~m}$ do ponto mais alto do terreno;

2. Colocar o lado $A$ do instrumento encostado na estaca e movimentar o lado B até que o sarrafo esteja nivelado pelo nível de bolhas. Colocar uma estaca neste ponto;

3. Girar o instrumento colocando o lado A na frente do B, repetindo a operação, sucessivamente, até o final da linha;

4. Quando houver variação na declividade do terreno, o procedimento deverá ser repetido para construção de uma nova nivelada básica, tomando-se o cuidado de evitar niveladas muito distantes, que diminuem a eficiência da técnica; ou muito próximas, que dificultam os tratos culturais quando ocasionam "ruas mortas".

O plantio em nível utiliza as próprias plantas para "quebrar a força" da água e não a deixar correr em escoamento superficial, o que promoveria o carreamento dos sedimentos que compõem as frações do solo. A prática é recomendada para terrenos que tenham inclinação de até $5 \%$ - acima dessa porcentagem, outras práticas vegetativas e mecânicas devem ser aplicadas (ANCAR, 1974; SOUZA, 2018).

De modo geral, as plantas utilizadas no plantio em curvas de nível, formam um cinturão verde, com espaçamentos estreitos, criando apenas um vão de passagens entre si, para a realização dos necessários tratos culturais: assim, o escoamento superficial e sub-superficial da água não carreia os sedimentos.

Em área declivosa, onde não é recomendado o preparo do solo com máquinas (aração, gradagens e sulcamento mecânico), a limpeza do terreno deve ser em faixas, com roçadas, capinas ou com uso de herbicidas (desde que não seja de produção orgânica e, ou, agroecológica) e, posteriormente, abrem-se as covas com a broca (operação mecanizada); ou manualmente (enxadão) (FERRÃo et al., 2012).

\subsection{Terraceamento}

Para se começar a proteger o solo devidamente, tem-se de criar uma mentalidade conservacionista. Por isso, torna-se vital ter em mente os princípios básicos da conservação do solo. 
Principalmente em áreas agrícolas, devem-se considerar os seguintes pontos: em primeiro lugar, procurar manter o solo coberto o máximo de tempo possível durante 0 ciclo das culturas e após a colheita, com o objetivo de minimizar e, ou, impedir o impacto direto da gota da chuva sobre o solo, que causa a destruição dos agregados do solo ("splash"), o entupimento dos poros e a formação de crosta superficial (BERTOLINI; LOMBARDI NETO, 1994).

Segundo esses mesmos autores, essa crosta, além de dificultar a germinação das sementes, reduz a infiltração da água no solo e contribui para a formação de enxurradas. Em segundo lugar, devem-se adotar práticas agrícolas que mantenham e, ou, elevem a capacidade de infiltração da água no solo e reduzam o escoamento superficial e a formação de enxurradas: outro agente muito importante que acelera a erosão.

A erosão hídrica do solo é o resultado da interação entre os fatores potencial erosivo da chuva (intensidade), suscetibilidade do solo à erosão (erodibilidade), comprimento do pendente, declividade do terreno, manejo do solo, de culturas e de restos culturais e práticas mecânicas conservacionistas complementares (GRIEBELER et al., 2005).

As práticas conservacionistas permitem o controle de perdas de solo e água em áreas agricultáveis, objetivando a maximização do lucro sem provocar redução da capacidade produtiva. A erosão consiste no processo de desprendimento e arraste das partículas do solo causado pela ação da água e do vento, constituindo-se na principal causa da degradação de terras agrícolas (PRUSKI; GRIEBELER, 1996).

Após o desenvolvimento de grupo de estudos do Brasil, no sentido do desenvolvimento de técnicas conservacionistas, a prática da construção dos terraços ganhou força nos anos da década de 1970, sendo utilizado tanto no sistema de preparo convencional com mobilização total do solo, como nos sistemas considerados conservacionistas, citando o "Cultivo Mínimo", com movimentação do solo verticalmente; e o "Sistema Plantio Direto", sem movimentação praticamente.

O terraceamento se trata de uma prática que combate a erosão baseada na implantação de terraços que objetivam controlar o volume de escoamento das águas da chuva (Figura 12). Essa é uma prática que deve ser associada a outras práticas de manejo do solo, por exemplo, cobertura do solo com palhada, calagem e adubação equilibrada, rotação de cultura com plantas de cobertura e cultivo em nível.

Essa associação de práticas compõe o planejamento conservacionista da lavoura de café. O custo de construção e manutenção de um sistema de terraceamento é relativamente alto; portanto, antes da adoção dessa tecnologia, deve-se fazer um estudo criterioso sobre as condições locais, tais como clima, solo, sistema de cultivo, cultivares a serem implantadas, relevo do terreno e equipamento disponível, para que se tenha segurança e eficiência no controle da erosão. O rompimento de um terraço pode levar à destruição dos demais que estiverem à jusante, com grandes prejuízos para a área cultivada (SOUZA, 2015).

O terraço tem uma estrutura transversal no sentido do maior declive do terreno, sendo composta de um dique e um canal, retendo e infiltrando nos terraços, a água da chuva (RESCK, 2002; WADT, 2004; BRSCAN, 2016). As características da chuva (quantidade, duração e intensidade); da paisagem (comprimento da rampa, rugosidade do terreno, profundidade e permeabilidade do solo); e práticas de manejo agrícola (mato nas entrelinhas e leiras vegetacionais), são fatores que determinam a distribuição dos terraços (RESCK, 2002; WADT, 2004; BRSCAN, 2016). 


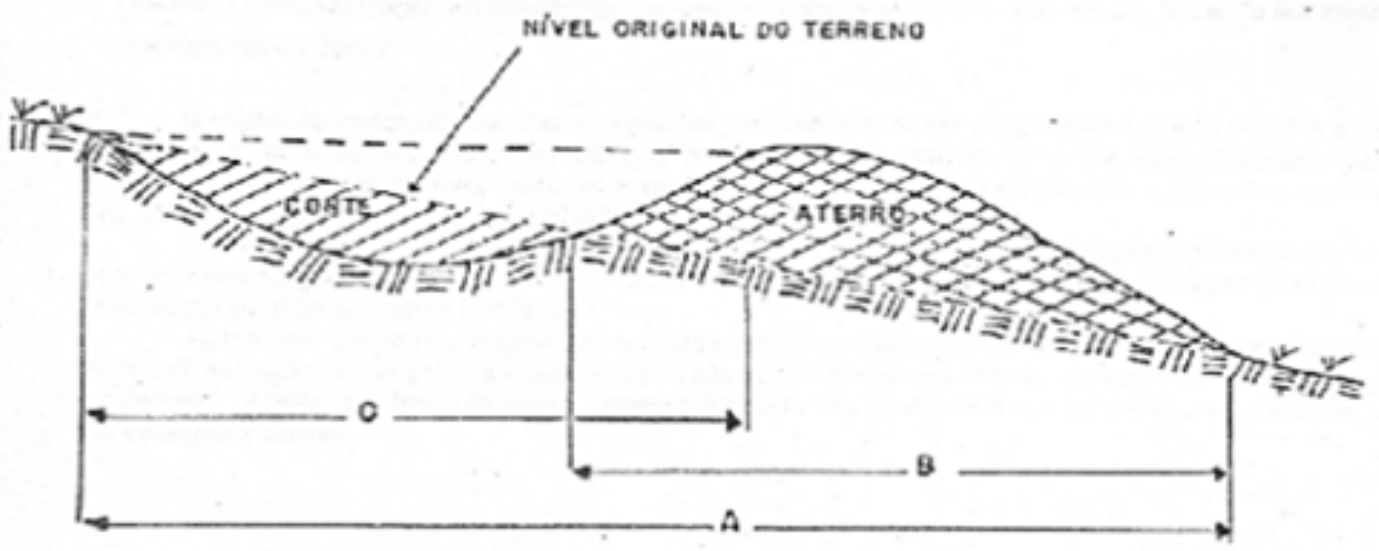

Figura 12. Marcação de um terraço. Fonte: Embrapa ACRE, 2004.

\section{Legenda:}

A: Faixa de movimentação de terra

B: Camalhão

C: Canal

Para o cálculo da declividade de um terreno, devem-se levar em consideração algumas medidas a serem tomadas em campo. É necessário escolher dois pontos quaisquer no terreno (ponto a e ponto $b$ ). No ponto mais baixo e mais alto do local escolhido, deve-se cravar uma estaca ou qualquer outro material que seja firme; em seguida, marcar a distância horizontal entre os dois pontos e fazer uma marca na estaca. Depois de realizado esse procedimento, deve-se medir a distância entre o chão e a marca feita na estaca (PIRES; SOUZA, 1999; SOUZA et al.; 1999).

Um terraço é composto de duas partes (Figura 13): a) canal coletor, de onde é retirada a massa de solo e; b) camalhão ou dique, construído com a massa de solo movimentada do canal.

Os terraços podem ser de base larga (Figura 13 superior) ou de base estreita (Figura 13 inferior). As características do terreno, principalmente a sua declividade e a granulometria do solo, irá definir qual das duas técnicas deverá se usar na lavoura de café que será estabelecida. A seleção do tipo de terraço mais eficiente deve ser realizada de acordo com a topografia do terreno, as características do solo, as condições climáticas, da cultura a ser implantada, o sistema de cultivo utilizado e a disponibilidade de máquinas na propriedade. A principal propriedade do terraço para controle da erosão é que ele tenha capacidade e segurança para reter a água do escoamento superficial (PRUSKI, 2009).

Para realizar o cálculo da construção de um terraço, é necessário dividir a distância vertical pela horizontal, e multiplicar o resultado por 100, de acordo com a Equação 1:

$\mathrm{D}=\mathrm{V} / \mathrm{H} \times 100$

(Equação 1)

Onde:

$\mathrm{D}=$ Declividade $(\%)$

$V$ = Distância do chão e à estaca

$H=$ Distância vertical do ponto A e B 


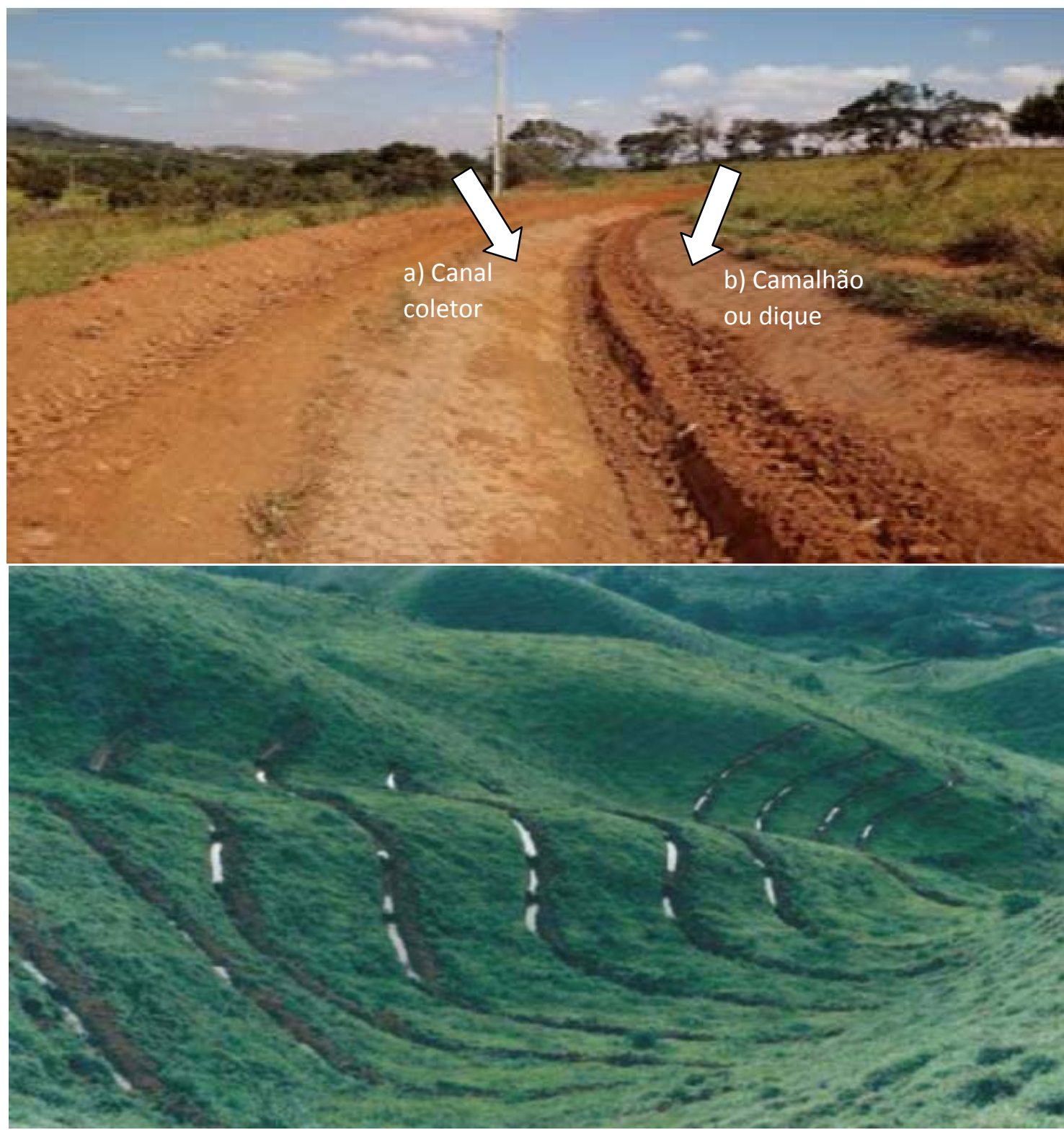

Figura 13. Acima. Construção de um terraço. Fonte: Adaptado pelos autores da Secretaria de Agricultura de Minas Gerais, 2020. Abaixo. Terraços de base estreita com acúmulo de água.

Com relação à manutenção, os terraços ao longo dos anos, sofrem transformações causadas por agentes externos, como transporte de máquinas, vento, infiltração de água das chuvas em função de construção de galerias por animais. Outro problema que se observa ao longo dos anos é o acamamento do terraço, perdendo sua forma regular e, consequentemente, sua funcionalidade. Diante dessa realidade, são importantes a avaliação periódica e a manutenção regular.

De acordo com Silva (2019), a dimensão dos terraços diz respeito à largura da faixa de movimentação de terra, sendo classificados como: terraço de base estreita, recomendado nas condições de alto declive; terraço de base média, indicado para pequenas e médias áreas, sendo utilizados os arados de disco ou de aiveca para movimentação do solo; e terraço de base larga, recomendado para grandes áreas com declividade entre $6 \%$ e $8 \%$ - neste caso, requer maquinário de grande porte denominado terraceador agrícola. 
Apesar de ser uma técnica conhecida e difundida no Brasil, esse mesmo autor afirma que ainda existe grande dificuldade quanto ao seu uso pela falta de conhecimento da importância da técnica para preservação das áreas agrícolas e, muitas vezes, pelo descaso do produtor agrícola. Um dos maiores problemas verificados a campo é o dimensionamento incorreto para a alocação dos terraços, levando em consideração as características do sistema de produção onde se pretende introduzir, reduzindo, desta forma, a sua eficiência.

De acordo com a topografia da região, recomenda-se que os terraços sigam os seguintes padrões (EMBRAPA, 2018):

- Até $12 \%$ - é indicado o uso do terraço de base larga, mesmo em área que, futuramente, seja transformada em pastagens, construído com lâmina terraceadora;

- De 12 a 15\% - é indicado o uso do terraço do tipo base estreita, construído com o arado terraceador de discos ou com lâmina terraceadora;

- Acima de $15 \%$ - recomenda-se o uso de terraços com faixa viva.

Em função das características de solo, topografia, condições climáticas, cultura a ser implantada, sistema de cultivo e disponibilidade de maquinário, define-se o tipo de terraço que melhor atenderá a cada gleba, buscando-se o eficiente controle da erosão, sem causar transtornos ao agricultor durante as operações agrícolas.

De acordo com a EMBRAPA (2018), as características físicas do solo, a declividade e a intensidade da precipitação determinam se o terraço será de infiltração (em nível) ou com gradiente (em desnível). A declividade do terreno é fator determinante na largura da faixa de movimentação de terra (terraço de base estreita, média ou larga) e na definição se o terraço será do tipo comum ou patamar (acima de 18\% de declividade, recomenda-se a construção de terraço do tipo patamar).

Ainda, de acordo com esse mesmo autor, a quantidade, intensidade e distribuição das chuvas são fatores fundamentais no volume do deflúvio superficial, que por sua vez deve ser levado em consideração no dimensionamento da capacidade de retenção e condução de água, assim como no espaçamento entre terraços. As culturas e o sistema de cultivo se relacionam diretamente com a intensidade de mecanização, que orientará na escolha do terraço de base estreita, média ou larga.

As máquinas e implementos disponíveis, assim como a situação financeira do agricultor, condicionam o tipo de terraço em função da maior ou menor capacidade de movimentação de terra. É importante que o terraço seja construído com capacidade e segurança para reter o excedente das águas pluviais, para posteriormente ela se infiltrar, ou na condução disciplinada das águas do deflúvio superficial, independente da sua forma. Os terraços devem receber manutenção periódica, como a limpeza do canal e do camalhão (Figura 14). 


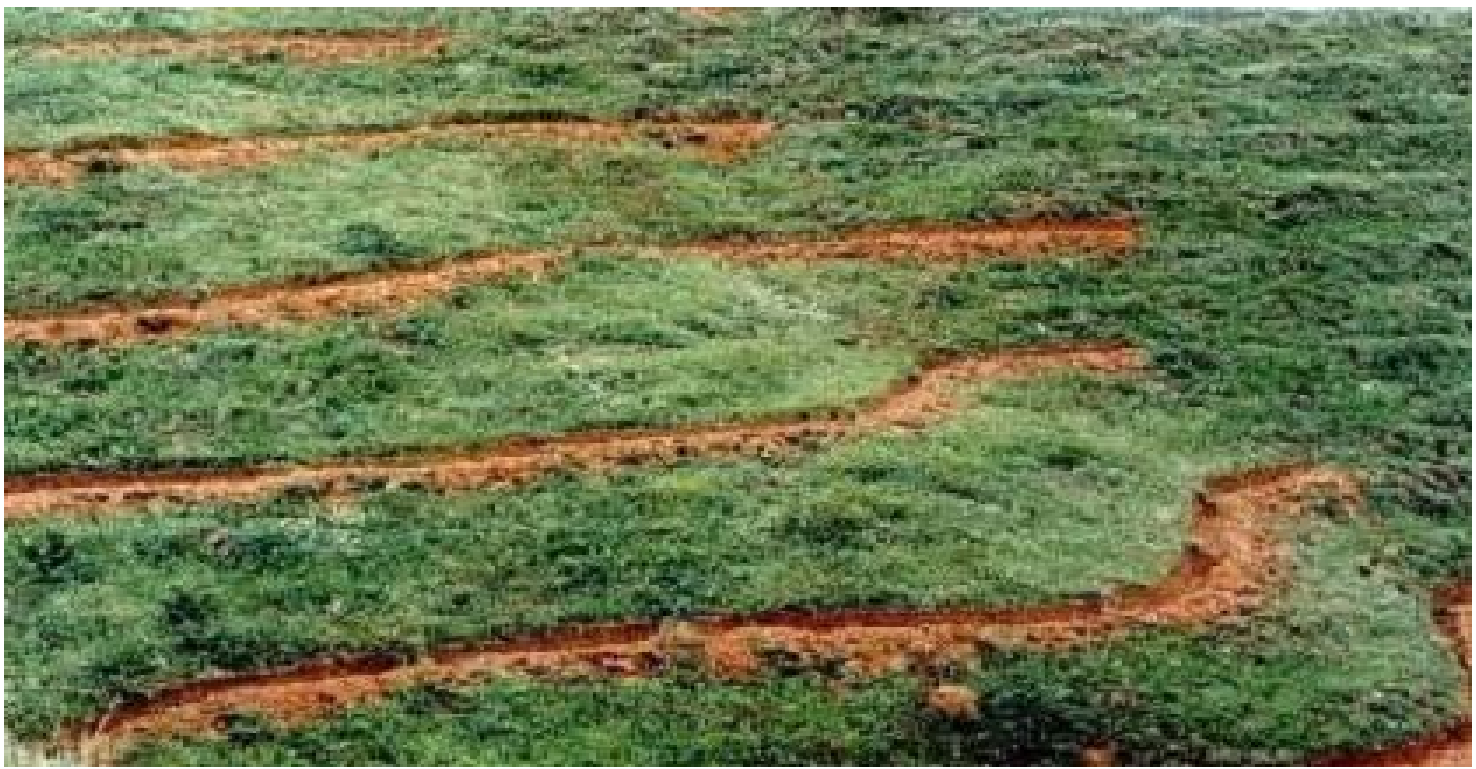

Figura 14. Terraços de base estreita em procedimento de manutenção.

Para que o sistema de terraceamento funcione com plena eficiência, é necessário o correto dimensionamento, tanto no que diz respeito ao espaçamento entre terraços, como em relação a sua seção transversal. O espaçamento entre terraços é calculado em função da capacidade de infiltração de água pelos solos, da resistência que o solo oferece à erosão, do uso e manejo do solo, enquanto a seção transversal deve ser dimensionada em função do volume de água possível de ser escoada pela superfície do terreno situada imediatamente acima do terraço. Das águas pluviais que caem na superfície do solo, parte se infiltra e o excedente escoa pela superfície, sendo recolhida pelo terraço. Se em nível, este deverá reter todo o volume de água escorrida para posterior infiltração. Quando em desnível, deverá dar vazão ao escorrimento superficial de forma disciplinada, sem causar erosão em seu interior (Figura 15).

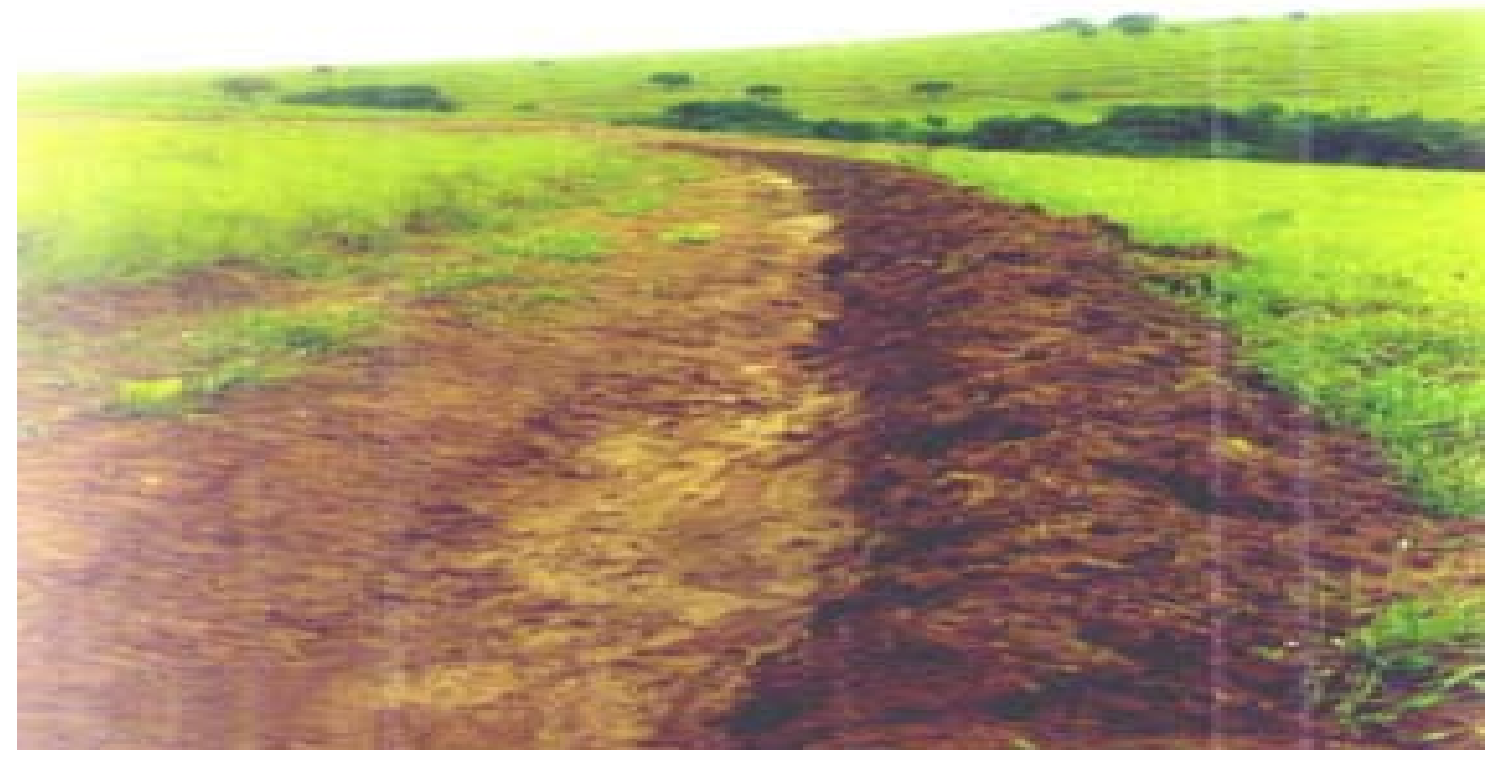

Figura 15. Detalhe de terraço com gradiente construído com arado de disco. Prados, MG (out/95). Fonte: EMBRAPA, 2018.

Mesmo o terraço sendo a prática conservacionista mais difundida entre os produtores, ainda existe muita erosão nas áreas terraceadas, sendo as seguintes principais causas diagnosticadas (BERTOLINI et al., 1993): 
- Utilização do terraço como prática conservacionista isolada: diminui a sua eficiência;

- Dimensionamento do espaçamento entre terraços utilizando tabelas empíricas ou adaptadas de outros países, com número pequeno e insuficiente de informações que não levam em conta as classes de solos identificadas em levantamentos pedológicos mais recentes;

- A maioria dos terraços construídos em nível sem considerar o tipo de solo. Dessa forma, nos solos menos permeáveis, principalmente aqueles com horizonte B textural ou que sejam rasos (profundidade menor do que 0,50 m), ocorrem fracassos, pois o fundo do canal do terraço pode vir a se localizar no horizonte $\mathrm{B}$, que se caracteriza por ter baixa taxa de infiltração, ou no próprio substrato rochoso. Como consequência, a água se acumula no canal até transbordar, causando o rompimento do camalhão do terraço, que é construído predominantemente com material mais arenoso do horizonte $A$;

- Nos solos com horizonte B latossólico, principalmente o Latossolo Roxo (na nova classificação - Latossolo Vermelho Distroférrico típico argiloso e muito argiloso), o uso intensivo e inadequado de máquinas e implementos pesados tem ocasionado a formação de camada compactada e pouco permeável, à profundidade de 0,10 a 0,20 m. Essa camada diminui a infiltração da água da chuva, aumenta o volume da enxurrada e contribui para o rompimento dos terraços devido ao transbordamento de água sobre os camalhões;

- As tabelas em uso não fazem distinção entre tipos de uso da terra, além de culturas anuais ou permanentes, embora as pesquisas tenham mostrado que diferentes culturas anuais e permanentes oferecem diferentes proteções ao solo no processo de erosão;

- As tabelas em uso também não levam em consideração o sistema de preparo do solo e o manejo dos restos culturais. Dados recentes de pesquisas comprovam que diferentes sistemas de preparo do solo e manejos de restos culturais possibilitam perdas de solo e água diferenciadas.

- Frequentemente, o terraço é construído com seção transversal menor que o necessário (ao redor de $0,60 \mathrm{~cm}^{2}$ a $0,70 \mathrm{~cm}^{2}$ ), fazendo com que, em solos permeáveis, não tenham capacidade suficiente para reter toda a água das chuvas.

Novas tabelas para o cálculo do espaçamento dos terraços foram desenvolvidas em função do efetivo controle da erosão, representando avanço por estarem apoiadas em dados de pesquisas sobre perdas por erosão de solo e água (Tabela 1).

Essas tabelas consideram a cobertura vegetal proporcionada pela época de ocorrência das chuvas (início ou fim do cultivo), os sistemas de preparo do solo e o manejo de restos culturais, além da erodibilidade de classes de solos identificadas em levantamentos pedológicos recentes (BERTOLINI et al., 1993).

Tabela 1. Espaçamento entre terraços de acordo com a declividade.

\begin{tabular}{ll}
\hline Declividade (\%) & Espaçamento $(\mathrm{m})$ \\
\hline 2 & 120 \\
$4-6$ & 90 \\
8 & 60 \\
10 & 30 \\
12 & 24 \\
$14-24$ & 18 \\
\hline
\end{tabular}

Fonte: BERTONI; LOMBARDI NETO, 1990; BERTOLINI et al., 1993. 


\subsubsection{Base estreita}

Apresentam abertura de até 3 metros de largura: não indicado para áreas de usos extensivos e com declividade inferior a 15\% (Figura 16).

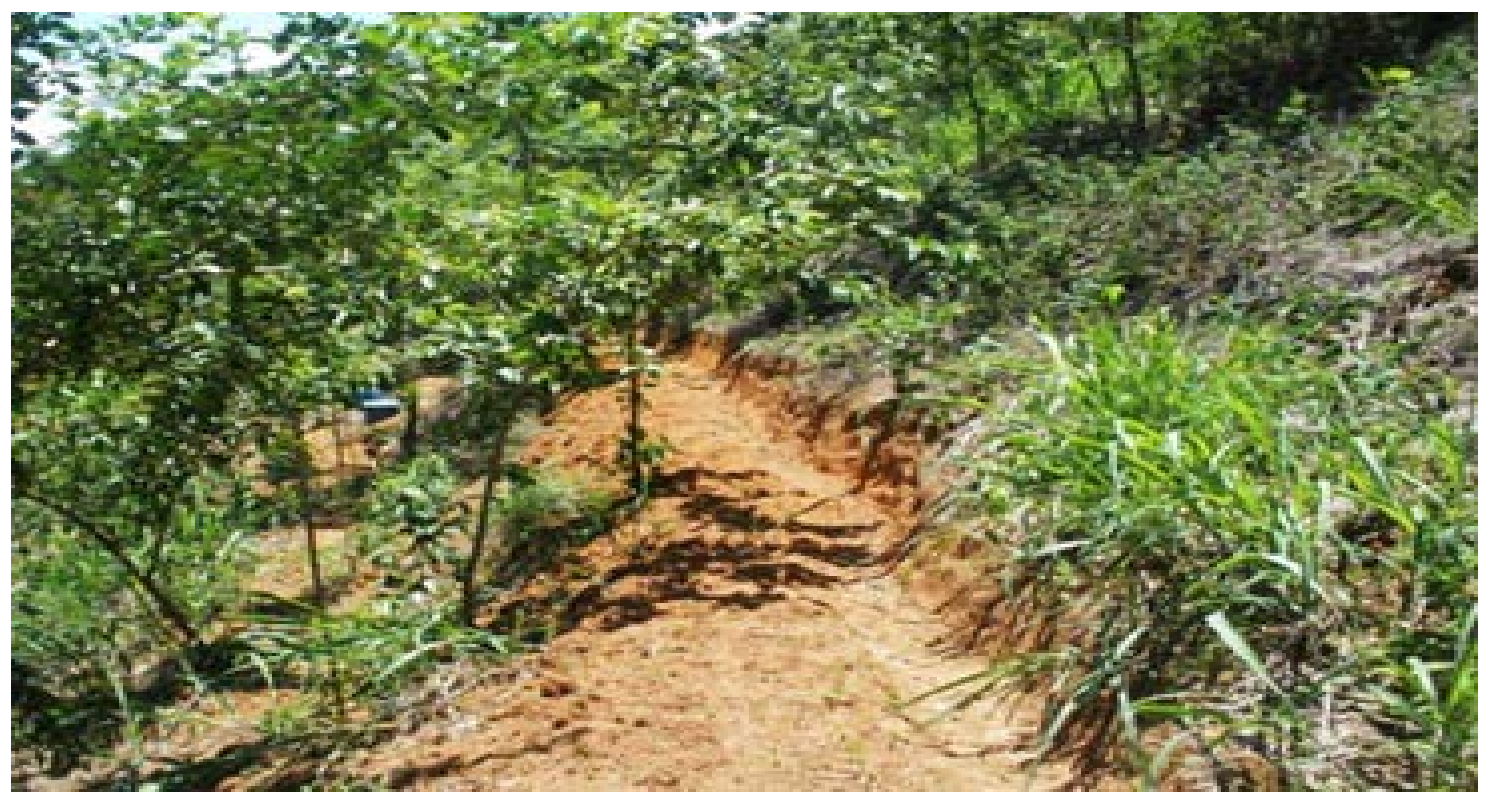

Figura 16. Terraço de base estreita no Sítio Jaqueira Agroecologia, Alegre, ES.

De acordo com a Epagri (2020), os terraços são construídos em nível, de modo a concentrar toda a água da chuva dentro da lavoura. Essa água se infiltra: parte vai para o lençol freático abastecer os lençóis freáticos; e a outra parte fica armazenada no próprio solo para atender à demanda das culturas. Nos terraços de base larga, 0 tamanho do camalhão (crista de terra) é calculado para que cada metro linear de terraço seja capaz de receber até 2 mil litros de água, em média.

Outra importante vantagem é a economia de adubo: os terraços evitam que a água escoe pela lavoura, carregando adubo e matéria orgânica. Nas propriedades onde 0 sistema está consolidado, os nutrientes ficam seis vezes mais concentrados no solo, segundo esses mesmos autores.

Contudo, a construção dos terraços precisa estar aliada a outras práticas de conservação do solo, como o "Plantio Direto". De acordo com a Epagri (2020), é fundamental ter em cada propriedade um plano de manejo conservacionista no qual sejam planejados os terraços e o sistema de produção com rotação de culturas, prevendo manter a cobertura permanente do solo. Esse planejamento de culturas deve garantir em torno de $12 \mathrm{~kg}$ de palha por metro quadrado por ano e raízes para absorver a água do solo: a cobertura do solo permite reter $25 \mathrm{~mm}$ a mais de chuva em relação ao solo descoberto.

\subsubsection{Base Larga}

A faixa de movimentação de terra é de 3 a $6 \mathrm{~m}$, com declividade de até 24\%. Seguindo todas estas recomendações técnicas de uso dos terraços nas lavouras, procura-se evitar erosão e perda de solo, acúmulo de água no solo, recarga dos aquíferos, evitar o assoreamentos nos rios, conservando solo e água no cultivo do café (Figura 17). 
Tanto os terraços de base estreita como os de base larga devem seguir as seguintes recomendações básicas:

- Os terraços, de base larga (4 $\mathrm{m}$ ou mais) ou estreita, também conhecido por "cordão de contorno" (0,90 a 1 m), devem ser construídos em nível ou com um pequeno declive ao longo da encosta;

- Com profundidade em torno de 0,50 m, cujo espaçamento entre eles, pode ser determinado conforme a Tabela 1;

- Deve-se evitar pontos de concentração do escoamento em um único local, posto que favorecerá a origem de processos erosivos, inclusive com formação de voçorocas.

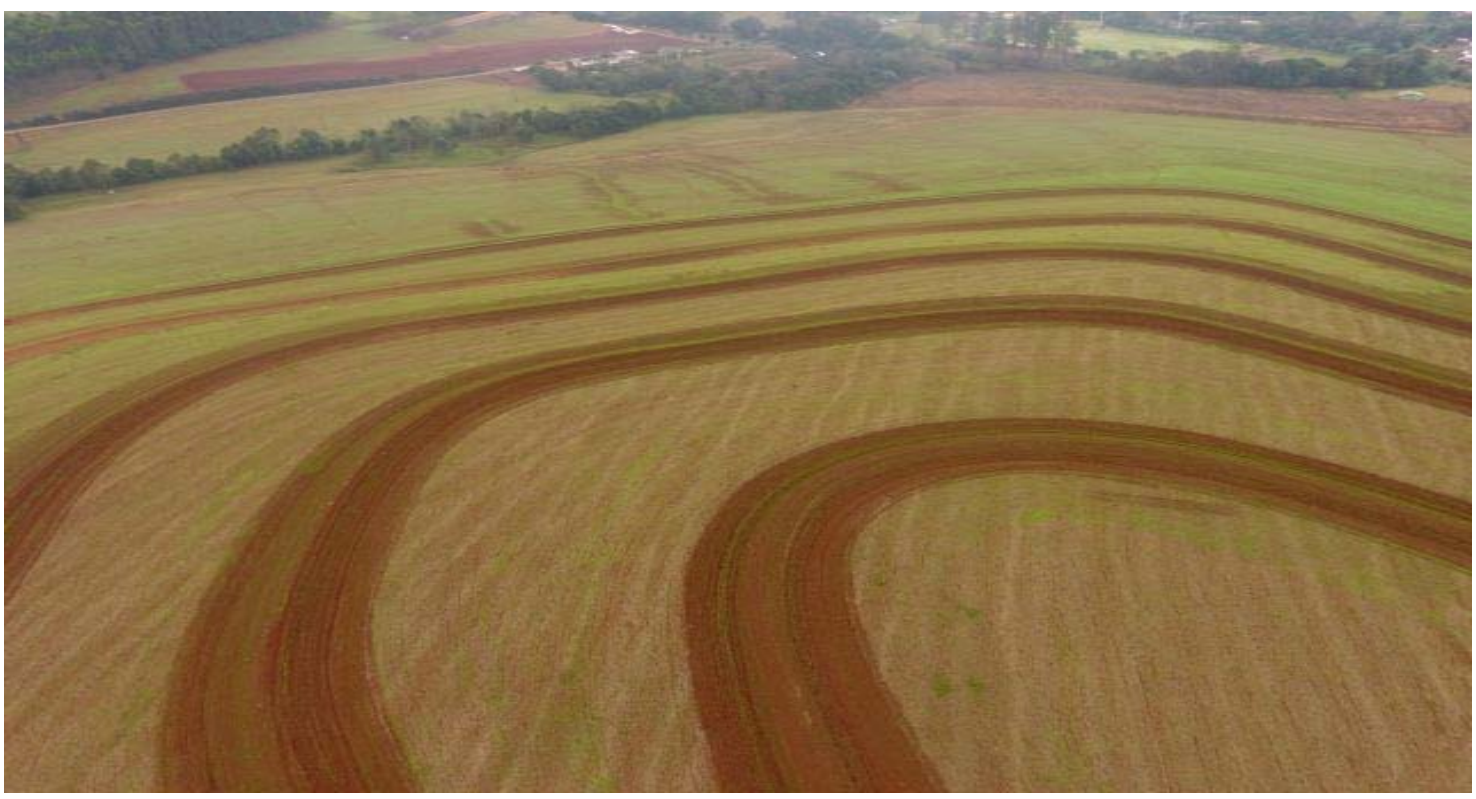

Figura 17. Terraço de base larga construídos em nível: aumento do tempo de concentração da água da chuva dentro da lavoura. Fonte: www.minutorural.com.br, 2020.

De acordo com a Epagri (2020), a prática do terraceamento é uma grande aliada do trabalho de conservação do solo e da água que ela realiza nas propriedades rurais do Oeste Catarinense. Capazes de proteger a lavoura da erosão nas chuvas intensas e armazenar água no solo para períodos de estiagem, os terraços de base larga já somam cerca de 1.000 ha em 80 propriedades rurais da região: são uma das práticas orientadas pela Empresa dentro de um projeto que envolve ações integradas de conservação do solo e da água, conduzido nas regiões de Xanxerê e Chapecó.

A metodologia introduzida pela Epagri se chama Terraço for Windows (Figura 17). Foi desenvolvida pela Universidade Federal de Viçosa (UFV) e validada pela Embrapa de Passo Fundo e agora também pelo grupo de trabalho da Epagri. De acordo com seus técnicos, esse método tem como base a declividade do terreno, a infiltração de água no solo e o histórico de chuvas da região. A tecnologia visa captar e armazenar água no solo e evitar a erosão e a degradação do terreno, com o objetivo de obter maiores ganhos de produtividade e rentabilidade das lavouras, além dos ganhos ambientais e sociais. 


\subsubsection{Microterraceamento}

Aliado ao árduo trabalho manual exigido pela cafeicultura em regiões de montanha se constata a escassez e o alto custo da mão de obra local. Assim, os cafeicultores são forçados a buscar trabalhadores em outras regiões, aumentando o custo de produção. O elevado custo de produção é um dos maiores problemas da cafeicultura de montanha do Espírito Santo (GALEANO; KROHLING, 2018).

A declividade do terreno dificulta a mecanização tradicional com equipamentos tratorizados. Para contornar esse problema, pode-se adaptar o terreno, o manejo da lavoura ou ainda as máquinas à situação de declive das áreas: o microterraceamento é alternativo para adaptação do terreno! Consiste na abertura de terraços de 1,2 $\mathrm{m}$ a 1,5 m de largura entre as linhas do cafeeiro, que permitirão a entrada de microtratores com diversos implementos. Isso facilitará o plantio, tratos culturais e colheita, reduzindo custos de implantação e manutenção com a mão de obra manual (CNA, 2018).

Outro ponto a ser considerado se refere à adaptação do manejo das plantas, permitindo o uso de mecanização com máquinas automotoras para tratos culturais e colheita, a semimecanização dos tratos culturais e a facilitação dos tratos manuais (Figura 18) (THOMAZIELLO; PEREIRA, 2008; MATIELLO et al., 2016).

Diversos cafeicultores de regiões declivosas do Espírito Santo e Minas Gerais iniciaram a implantação dessa técnica com uso de trator de pneus com lâmina dianteira e traseira, trator de esteira (Figura 18) e do tipo "Bobcat", operando com concha e lâmina. Pequenos produtores podem, ainda, construir microterraços com tração animal ou realizar a abertura manual com enxadão (MATIELLO et al., 2016).

Como a introdução do uso de qualquer tipo de mecanização interfere no custo de produção da lavoura, o estudo dessa prática e do custo a curto, médio e longo prazo é de grande importância para se tomar a decisão. Sua contribuição ao meio ambiente, quando adotada de forma correta, pode ser observada na maior infiltração da água da chuva, propiciando a conservação do solo, diminuindo a erosão e preservando as condições de fertilidade das lavouras (MAGALHÃES, 2013; EUTRÓPIO; KROHLING, 2018).

O microterraceamento proporciona melhores condições de trabalho, mesmo quando realizado de forma manual nos tratos culturais como adubações, podas e colheita, com uso de motopodas e derriçadeiras portáteis, preservando a saúde e promovendo a qualidade de vida do trabalhador (KROHLING et al., 2018).

Podas constantes nas lavouras têm sido muito utilizadas nas regiões do sul de Minas Gerais e no Cerrado (áreas mecanizadas) visando zerar a safra no ciclo de baixa produção. Esse sistema recebeu o nome de "Safra Zero" ou "Super Safra", pois é preciso promover safras altas para obtenção de altas produtividades médias, alternada com a safra zerada pela intervenção da poda. Normalmente as podas de esqueletamento e decote são usadas simultaneamente na lavoura. Entretanto, esse modelo de manejo ainda é pouco utilizado nas regiões de montanhas de produção de arábica, devido à dificuldade de adaptação das máquinas ao terreno declivoso (KROHLING; SOBREIRA, 2018).

De acordo com esses mesmos autores, o bom rendimento da colheita semimecanizada em café arábica também foi constatado na Região das Montanhas do Espírito Santo, tanto em lavouras implantadas em curva de nível, quanto em "morro acima" com uso de máquina recolhedora de lona. O sistema simultâneo de colheita 
semimecanizado com poda no sistema "Safra Zero" na região de montanhas pode ser aplicado para reduzir custos e facilitar a colheita.

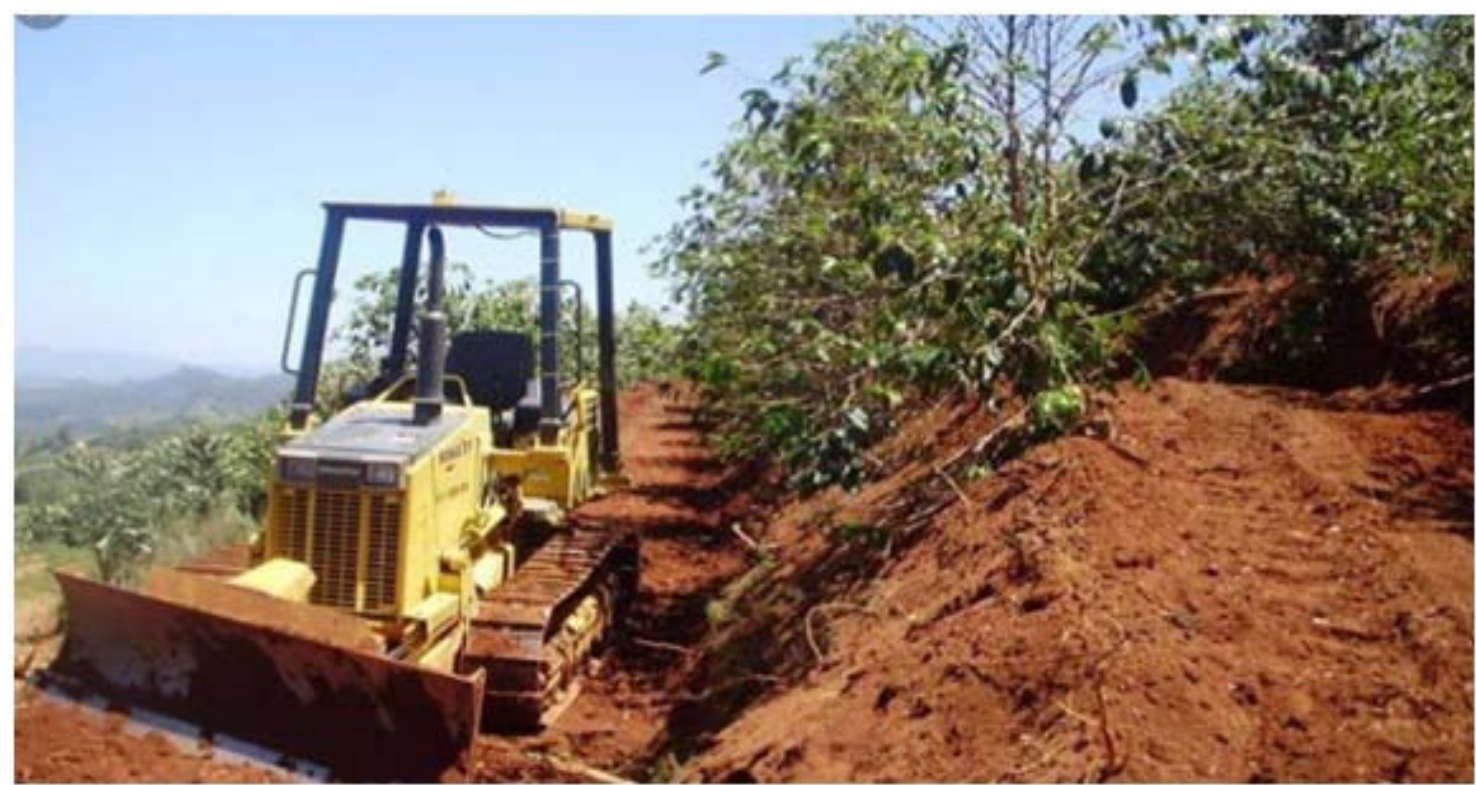

Figura 18. Construção de microterraceamento em uma lavoura cafeeira. Fonte: CAFEPOINT, 2020.

Alves; Pereira; Dalchiavon (2017) realizaram estudo de caso com uso de terraceamento na Região de Montanhas de São Paulo e concluíram sua viabilidade econômica, principalmente pela redução do custo de produção, por meio da diminuição da mão de obra, tanto nos tratos culturais como na colheita. Estudo realizado por Bordin et al. (2019) em lavoura de primeira safra, comparando a colheita manual e mecanizada, mostrou que os danos causados pela colheita manual ou mecânica não interferem na produção da safra seguinte.

De acordo com Matiello (2019), a técnica de microterraceamento em cafezais é uma das mais promissoras opções de manejo, tendo evoluído de forma significativa nos últimos anos: seja na ampliação dos sistemas e maquinário para sua execução, seja no aumento da área trabalhada, dando base e segurança para seu uso extensivo, na cafeicultura em áreas montanhosas (Figuras 19 e 20).
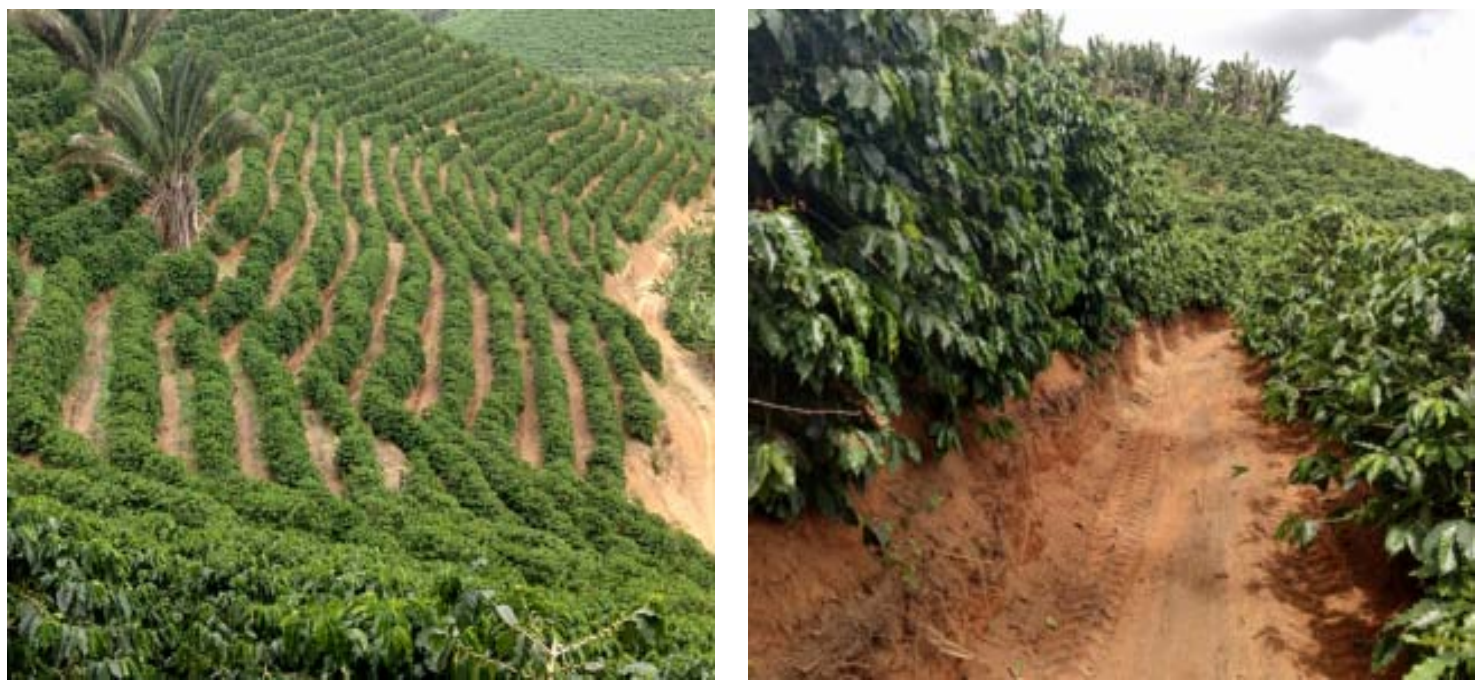

Figuras 19 e 20. Vista geral e detalhe de microterraceamento em lavoura de café arábica, em Marechal Floriano, ES. Fonte: TRISTÃO et al., 2019. 
Segundo Matiello (2019), o microterraceamento, diferentemente do terraceamento tradicional, visa principalmente, facilitar o trânsito e a mecanização dos tratos das lavouras de café, em zonas montanhosas, nas quais a exploração vem sendo feita de forma manual, com custos mais elevados. A partir do momento em que o terraço é aberto nas ruas do cafezal, podendo ser feito antes do plantio ou após, na lavoura em formação ou já adulta, o trabalho de manejo e colheita serão bastantes facilitados. 0 espaçamento mais adequado, para facilitar o manejo, deve ser em torno de $3-3,5 \mathrm{~m}$ na rua, dando origem a um terraço um pouco mais largo (Figura 21).

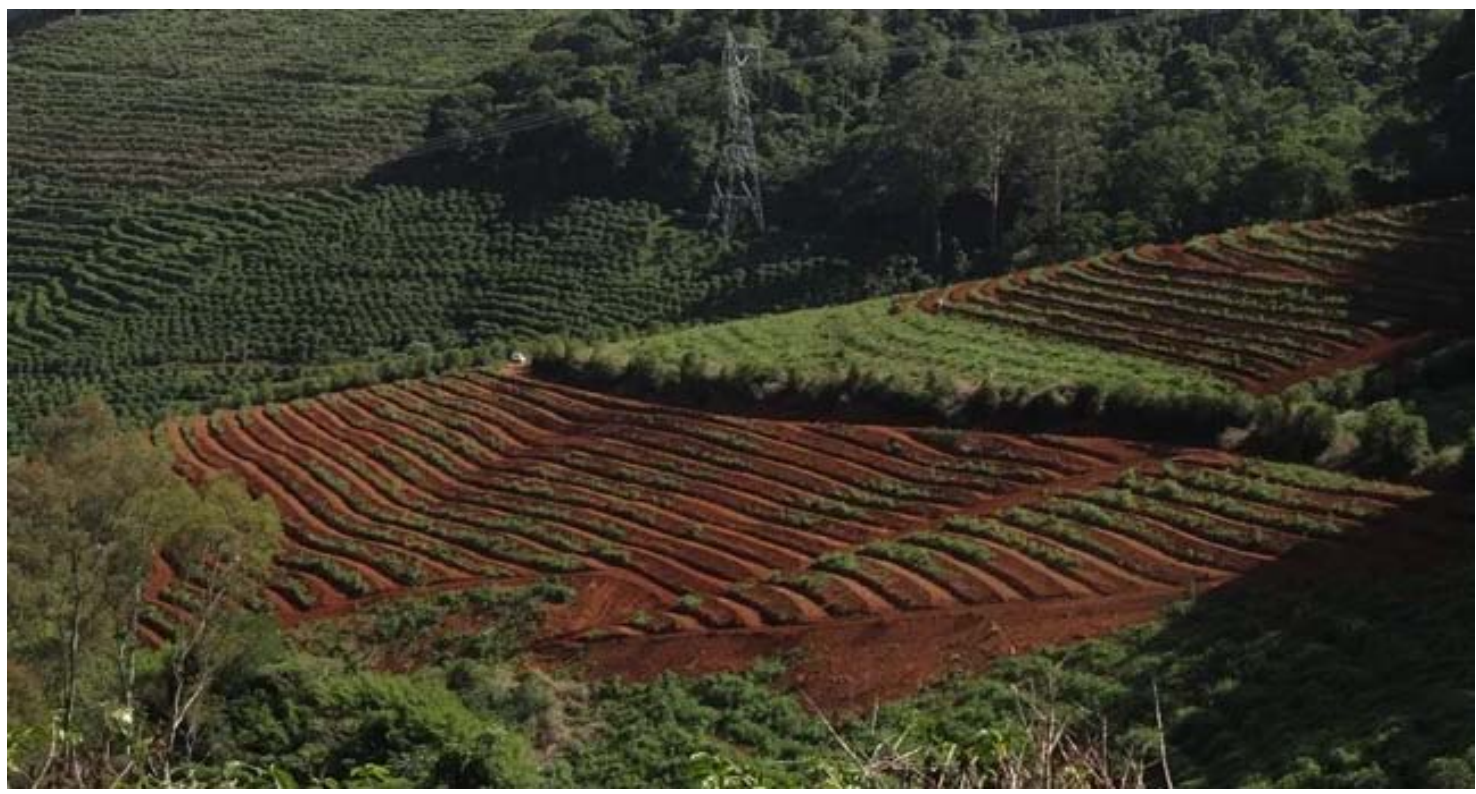

Figura 21. Vista geral de área microterraceada antes do plantio do café, em espaçamento de 3 x 0,5m. Fonte: Matiello, 2019.

De acordo com Matiello (2019), os sistemas de abertura dos terraços podem ser os mais diversos: desde com o uso do próprio enxadão, manualmente; ou com uso de arado de bois ou microtratores operando de ré (nas pequenas propriedades). Para as áreas de maior tamanho, pode-se usar o trator normal, com lâmina traseira, operando também de marcha ré, ou, ultimamente, com maior segurança, com uso de trator de esteira, de menor potência e mais estreito, este operando com lâmina dianteira e andando para frente, resultando em bom rendimento operacional e um custo bem compatível.

Máquinas tipo escavadeira também podem ser usadas, existindo no mercado uma mini-escavadeira, com esteira de borracha e bem estreita, podendo ter até menos de $1 \mathrm{~m}$ de largura. Deste modo, é útil para usar em lavouras que tenham espaçamentos mais apertados na rua.

As primeiras lavouras microterraceadas já têm mais de cinco (5) anos. Tem sido observado que os terraço melhoram bastante a retenção de água na área, reduzindo a erosão. O pequeno barranco deixado, do lado acima do terraço, consolida-se rapidamente, sem prejuízo para o sistema radicular dos cafeeiros.

\subsection{Tecnologia de curvas de nível com "cochinhos"}

Segundo a Prefeitura Municipal de Atílio Vivácqua, por intermédio da Secretaria Municipal de Meio Ambiente, o "Projeto Cochinhos em curva de nível" foi o único representante do Espírito Santo entre os quatro finalistas da Campanha Nacional de 
Combate à Erosão, promovida pela Empresa Brasileira de Pesquisa Agropecuária (Embrapa).

Tem como objetivo incentivar a construção de estruturas para captação de água em propriedades rurais do município e, assim, promover a recuperação de pastagem e de solos com erosão. Como se observa na Figura 22, a água captada é direcionada para o interior da lavoura de café. Infiltrando no solo, irá beneficiar de forma significativa a lavoura, bem como aumentará a recarga do lençol freático, perenizando as nascentes e regularizando a vazão dos corpos hídricos.

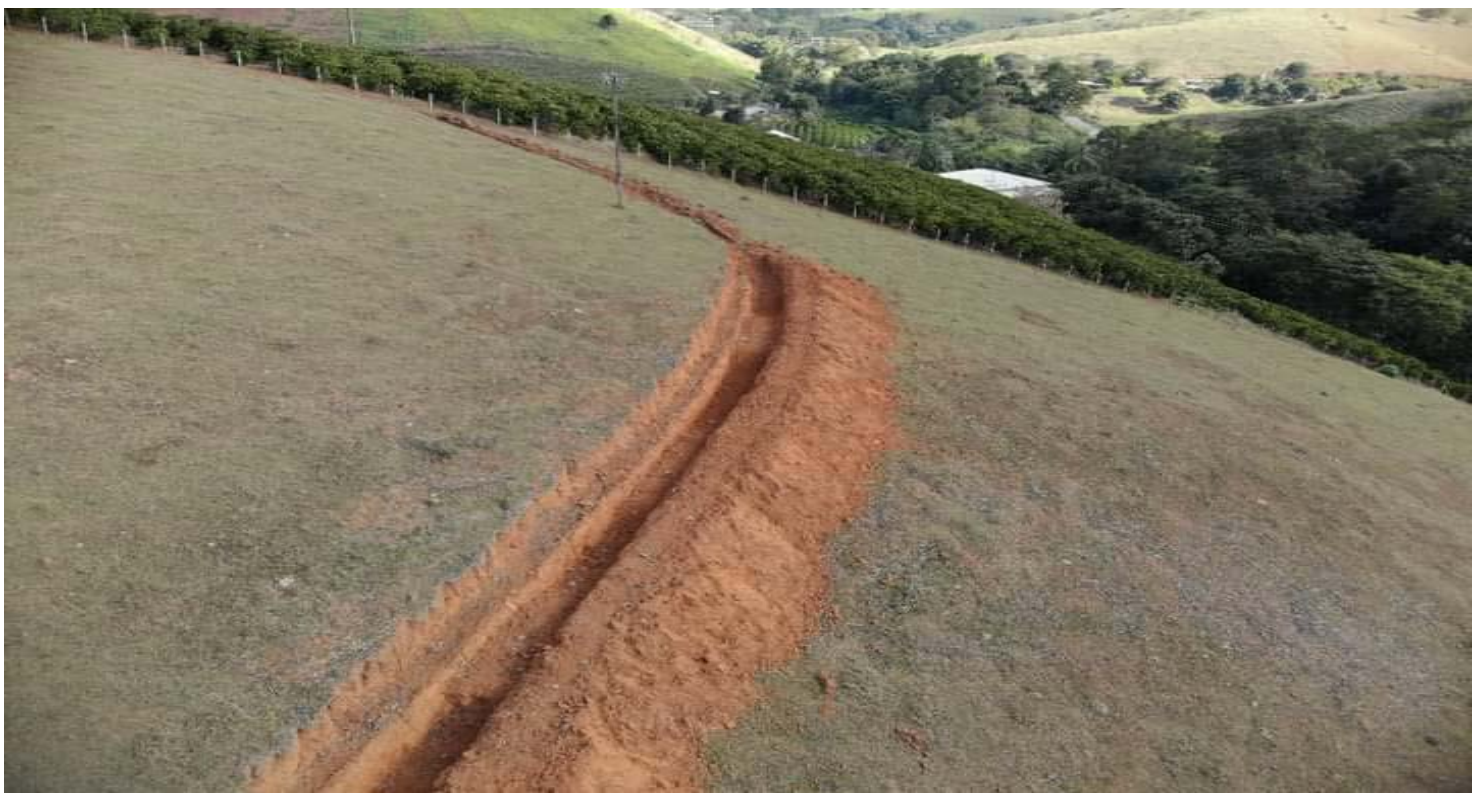

Figura 22. Cochinho em nível da pastagem ao interior da lavoura de café. Fonte: Embrapa Sorgo e Milho - Projeto Barraginhas, 2020.

Além dos benefícios clássicos do terraceamento, os cochinhos vêm sendo muito utilizados para distribuir água residuária do beneficiamento do café no perfil do solo onde se tem uma lavoura estabelecida. (Figuras 23 e 24).
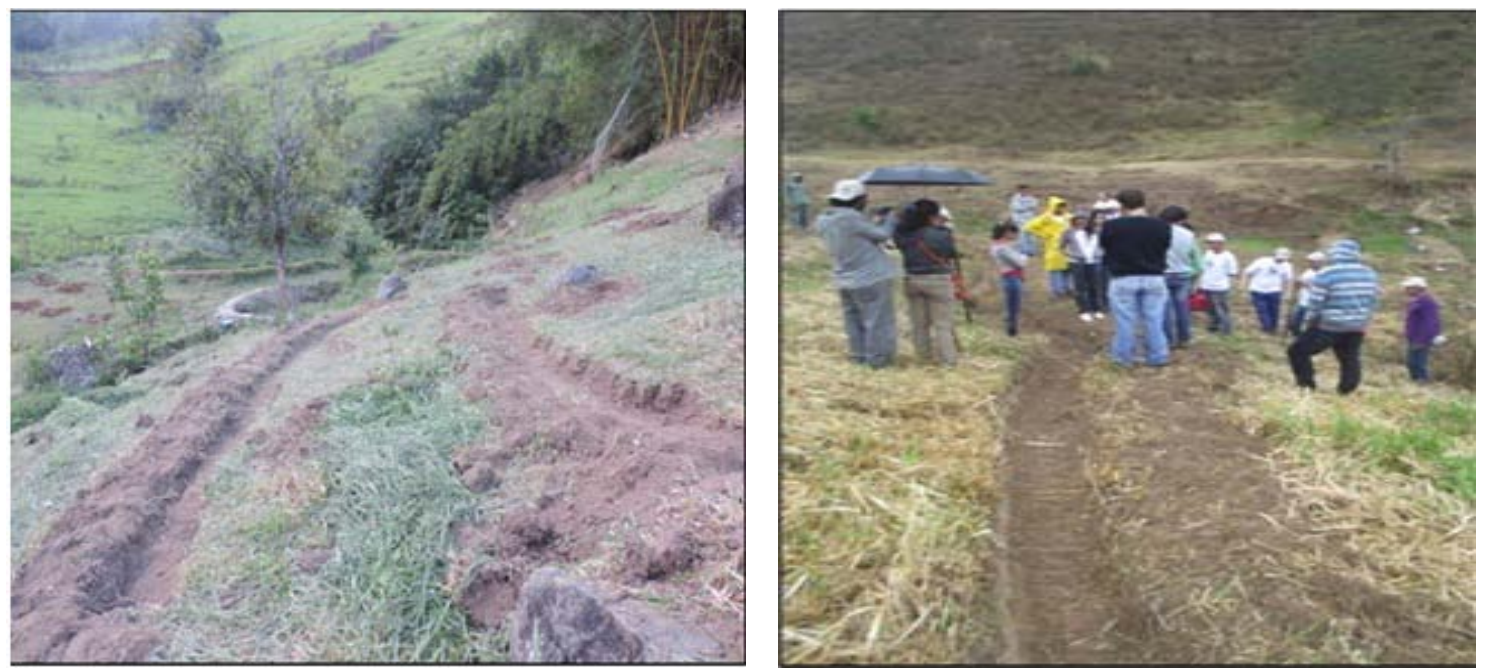

Figuras 23 e 24. Construção de um "cochinho" em uma lavoura cafeeira. Fonte: CAFEPOINT, 2020. 


\subsection{Caixa seca ou "barraginhas"}

Este sistema consiste na instalação de um reservatório na margem de estradas rurais para captação das águas de chuva, visando evitar enxurradas, a erosão, o assoreamento dos córregos e rios, bem como reduzir a depredação das estradas pela chuva. Ainda, aumentar o armazenamento de água, o abastecimento do lençol freático, além de favorecer as nascentes e a vazão dos rios (ALBUQUERQUE; DURÃES, 2008; SOUZA, 2015).

De fato, nada mais é que um "buraco" cavado em encostas nas margens das estradas que capta a água da chuva e os sedimentos por ela levados. Este método evita enxurradas, voçorocas, assoreamento dos rios e depredação das estradas. Além disso, contribui para o abastecimento do lençol freático e a regularização da vazão dos rios (Figuras 25 e 26).

Alguns cuidados e precaução deverão ser tomados para a construção de uma caixa seca:

a) Manter as estradas e arredores da caixa, sempre cobertas por vegetação e fazer o controle do mato com roçadas, evitando erosão e assoreamento;

b) Manter os canais de ligação entre as estradas e as caixas secas sempre limpos;

c) Não construir caixas em solos arenosos e em solos rasos, com camadas rochosas, evitando desmoronamento e enchimento rápido das caixas secas.

Em áreas de café implantados em áreas de relevo muito acidentado, como na região serrana do Espírito Santo e nas Matas de Minas, a construção de caixas secas deve ser de formato trapezoidal ou retangular, construído as margens das estradas rurais. Quando a estrada tiver pouca cobertura vegetal, as caixas deverão ter um sistema de drenagem para eliminar o excesso de água e detritos que venha a cair dentro da caixa.

A construção dessas caixas deve ser baseada de acordo com cálculos de vazão, capacidade em $\mathrm{m}^{3}$ de sedimentos que a mesma deve suportar, e a localização ideal para a instalação. Na cultura cafeeira costumam ser feitos no final entre as fileiras na parte externa ou nos carreadores da lavoura (PELISSARI; PERINI; MIRANDA, 1997; ALBUQUERQUE; DURÃES, 2008).
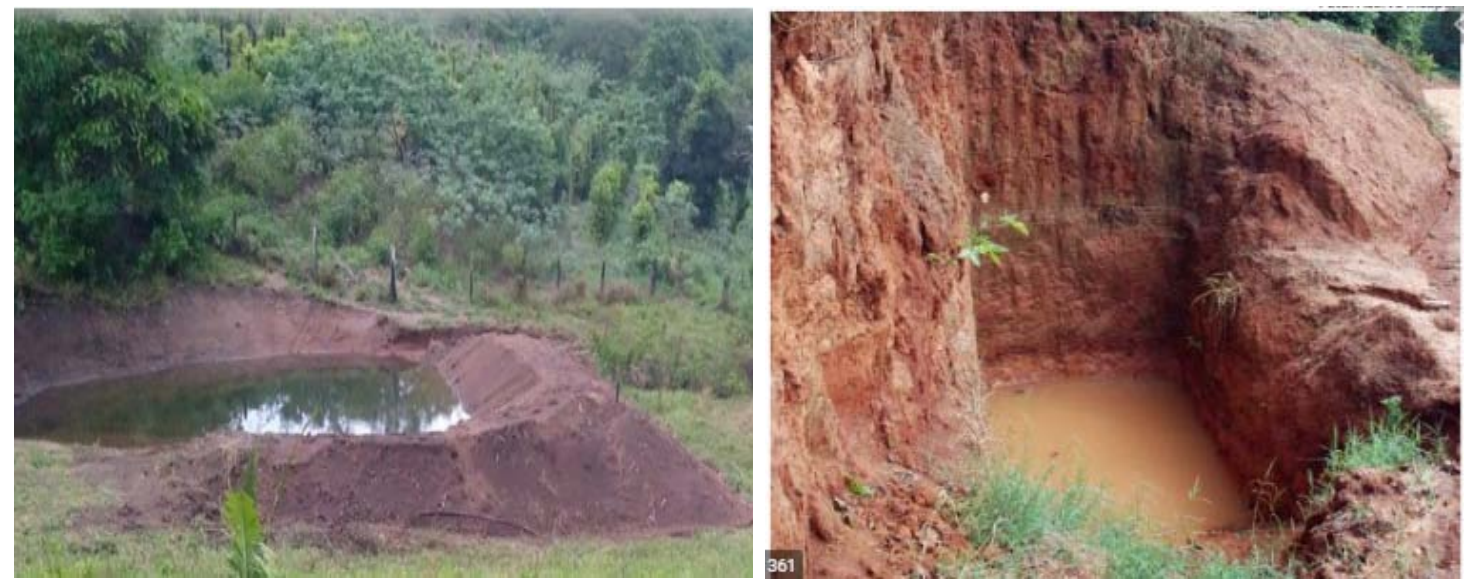

Figuras 24 e 25. Construção de barraginha em lavoura cafeeira e na margem de estrada. Fonte: LEAL; FERNANDES; PEREIRA, 2012. 
O tamanho da caixa seca e o espaçamento entre elas serão determinados pelo volume de água captada diretamente pelas estradas. A equação (2) é usada para o dimensionamento de uma caixa seca:

$V=A \times P \times C$

(Equação 2)

Onde:

$V=$ Volume total da água escoada a ser armazenada pelo sistema de captação $\left(\mathrm{m}^{3}\right)$;

$A=$ Área da estrada $\left(\mathrm{m}^{2}\right)$;

$\mathrm{P}=$ Precipitação de projeto $(\mathrm{mm})$;

C = Coeficiente de escoamento superficial da água na estrada (adimensional).

A caixa seca é um método muito eficiente para conservação do solo e água: além de evitar erosão, assoreamento dos rios, ajuda abastecer o lençol freático e conservar as estradas (Figura 26).

Também, poderão ser construídas em depressões da área onde se fará o plantio, observando o caminho preferencial das águas de chuva - facilmente identificáveis devido à formação côncava onde se originam, formando pequenos canais naturais na paisagem. Em lavouras de café, a produtividade na área de alcance das barraginhas, a produtividade por ser até duas vezes superior aqueles fora de sua área de abrangência (SOUZA et al., 2020).

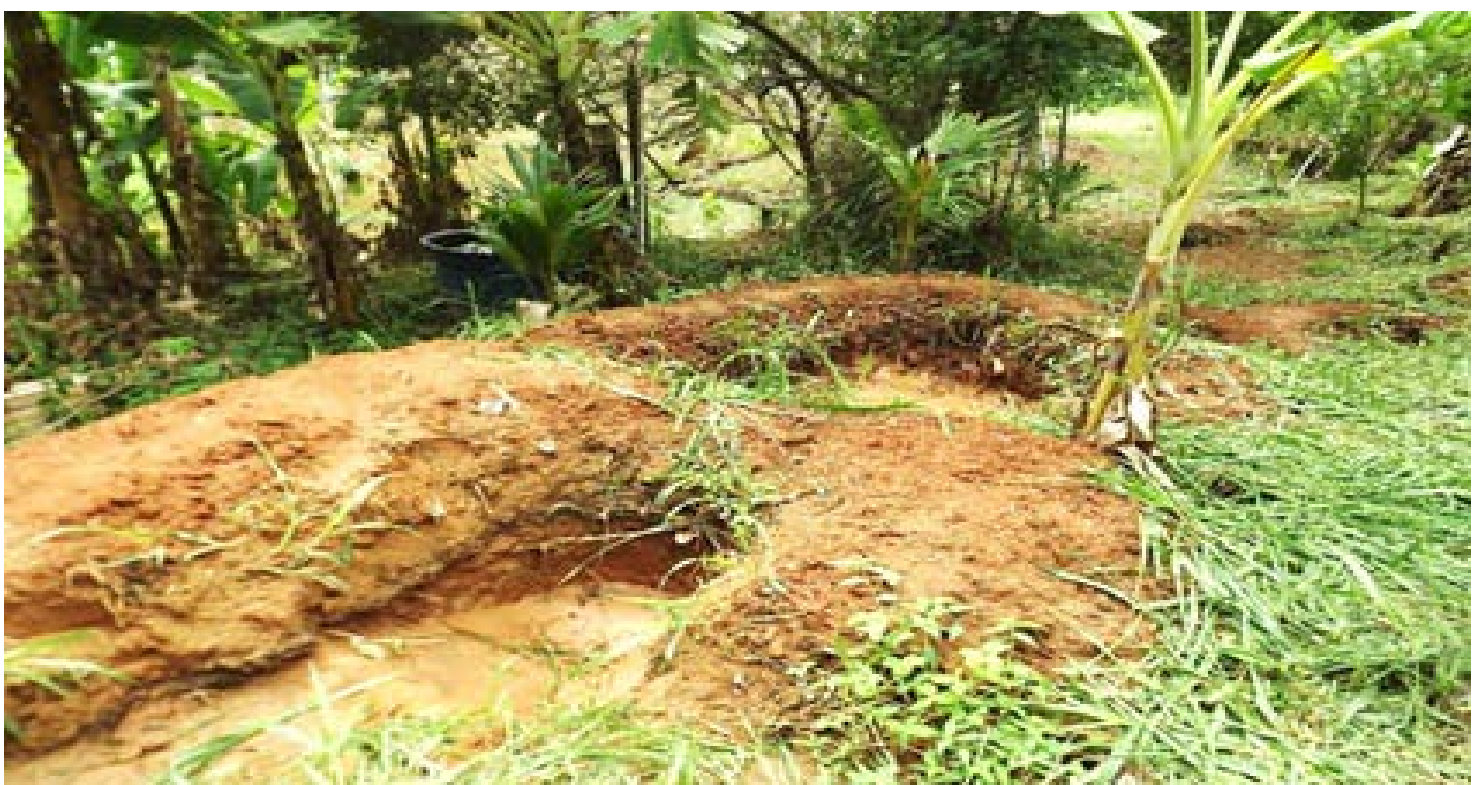

Figura 26. Caixa seca no Sítio Jaqueira Agroecologia, Alegre, ES. Fonte: Acervo Sítio Jaqueira Agroecologia.

\subsection{Adubação verde (pré-plantio com leguminosas)}

Nas últimas décadas, tornou-se crescente a busca por alternativas de manejo que cooperem para a manutenção ou melhoria da qualidade do solo com incrementos na produtividade. Deverão proporcionar benefícios ao meio ambiente e menores custos de produção pela redução do uso de fertilizantes químicos (TEIXEIRA et al., 2012). 
A adubação verde surgiu como uma opção: é uma prática milenar utilizada por muitos agricultores nos dias atuais com o objetivo de melhorar as propriedades físicas, químicas e biológicas dos solos, produtividade e qualidade das culturas de interesse econômico. Funciona também, no manejo de plantas espontâneas, na adequação da propriedade para implantação do sistema de produção agroecológico e, ou, orgânico e, principalmente, com o objetivo de redução dos custos de produção.

Um dos seus principais e mais importantes benefícios, está relacionado ao uso de espécies de plantas, principalmente da família Fabaceae ou Leguminosae, que se associam a bactérias fixadoras de nitrogênio do ar, retirando o nitrogênio $(\mathrm{N})$ do ar e disponibilizando-o no solo para as plantas. A fertilidade do solo e o uso inadequado de calagem e adubações, principalmente com N, são considerados os principais fatores responsáveis por baixas produtividades em áreas destinadas à produção (SOUSA et al., 2018; MARTINS et al., 2019).

De acordo com esses mesmos autores, o $\mathrm{N}$ é um macronutriente essencial para 0 pleno desenvolvimento vegetal e um dos seus maiores limitantes. Adubações nitrogenadas e a decomposição de matéria orgânica controlam a disponibilidade de $\mathrm{N}$ no solo para as plantas, sendo que, quando são utilizadas culturas com baixa relação entre carbono e nitrogênio na matéria seca, em rotação, a decomposição e a mineralização são mais rápidas e a ciclagem do $\mathrm{N}$ ocorre em curto período de tempo, diminuindo, entretanto, a proteção do solo. Por outro lado quanto mais altos forem a relação $\mathrm{C} / \mathrm{N}$ nos resíduos, mais lenta será a decomposição.

Dessa forma, o uso da adubação verde é uma alternativa sustentável em modelos de produção, também, no cultivo do café. Os benefícios das culturas de cobertura foram observados por vários autores, evidenciando melhorias nas propriedades químicas e físicas do solo (EIRAS; COELHO, 2011; SOUSA et al., 2018; MARTINS et al., 2019). Entre os efeitos da adubação verde sobre a fertilidade do solo, destacam-se: o suprimento de matéria orgânica; maior disponibilidade de nutrientes; e maior capacidade de troca de cátions efetiva do solo. Além disso, tais alterações são importantes no ciclo orgânico natural, regulando processos biogeoquímicos e facilitando relações simbióticas (CARDOSO et al., 2014; SOUSA et al., 2018).

Dentre as plantas utilizadas na adubação verde, destacam-se algumas leguminosas: crotalária (Crotalaria juncea), lab-lab (Dolichos lablab), mucuna preta (Mucuna aferrima) e puerária (Pueraria phaseoloides). Estas espécies apresentam a capacidade de fixar biologicamente o nitrogênio e disponibilizá-lo para a cultura sucessora (TEODORO et al., 2011; EIRAS; COELHO, 2011; FERRARI NETO et al., 2012). Sejam espécies de porte arbóreo, arbustivo ou herbáceo, tais exemplares apresentam alto grau de rusticidade, elevados acúmulos de biomassa, atuando ainda como reguladoras da temperatura e umidade do solo e na proteção dos riscos de erosão.

Além disso, elevam a eficiência na ciclagem de nutrientes, principalmente pela alta relação de $\mathrm{C} / \mathrm{N}$, favorecendo culturas agrícolas e silviculturais (BERNARDES et al., 2010; LEITE et al., 2010). Para tanto, é preciso conhecer as peculiaridades de cada exemplar, além de suas respostas diante das diferentes condições e consórcios na qual será implantada (CARVALHO et al., 2015; TORRES et al., 2015; MIRANDA et al., 2018).

A análise da ciclagem de nutrientes surge como instrumento para conhecer a dinâmica dessas relações, indicando o poder de estabelecimento e suporte ecossistêmico de cada indivíduo. É possível também, avaliar a qualidade e quantidade do serviço de 
manutenção, acréscimo de nutrientes e estoque de carbono no solo (VITAL et al., 2004).

Vários estudos vêm demonstrando que a técnica de adubação verde é responsável pela melhoria das condições físicas, químicas e biológicas do solo. Leguminosas que utilizam da associação de bactérias fixadoras de nitrogênio o transferem para a planta e estimula o desenvolvimento da população de fungos micorrízicos: esses aumentam o volume de raízes, favorecendo a absorção de água e de nutrientes pelas raízes. A fixação de nitrogênio pode ser obtida, também, por intermédio da inoculação prévia das sementes; porém, é uma técnica mais onerosa (EMBRAPA, 2011; ZACARIAS et al., 2019).

Além das referidas características citadas, as leguminosas são escolhidas por ser rústicas, terem elevada produção de matéria seca e graças ao seu sistema radicular, geralmente profundo e ramificado, são capazes de extrair nutrientes das camadas mais profundas do solo e, quando decomposta, retorna esses nutrientes ao solo (Ciclagem de nutrientes), sendo importantes fontes de matéria orgânica, de excelente qualidade (ARF et al. 1999; SOUZA, 2018).

No novo conceito de agricultura sustentável, agricultores precisam perceber a importância de valorizar a saúde geral do agroecossistema e de restabelecer relações biológicas que podem ocorrer naturalmente na unidade produtiva (SANTILLI; BUSTAMANTE; BARBIERI, 2015). As leguminosas fabáceas são as mais divulgadas como adubos verdes: muito em decorrência da simbiose com bactérias fixadoras de nitrogênio atmosférico. Diversas outras espécies, tais como as gramíneas (poáceas), crucíferas e compostas, são denominadas mais frequentemente como plantas de cobertura do solo (ANGELETTI et al., 2018).

Fernandes; Barreto; Emídio Filho (1999) apontam ainda como características favoráveis da utilização da adubação verde com leguminosas, o efeito alelopático e supressivo sobre as plantas daninhas, como ocorre com o feijão-de-porco, a crotalária e a mucuna-preta. Dentre as leguminosas promissoras para a prática da adubação verde em consórcio com o cafeeiro, destacam-se: a Crotalaria juncea (Crotaláriajuncea), o Cajanus cajan (Feijão-guandu), a Mucuna pruriens (Mucuna-preta), a Glycine Max L. (Soja) e a Tithonia diversifolia (Margaridão mexicano). Essas espécies apresentam desenvolvimento vegetativo eficiente, com boa adaptação em condições adversas, tais como a baixa fertilidade e altas temperaturas (PEREIRA et al., 2017).

Conforme ANGELETTI et al. (2018), a disponibilidade de várias espécies de plantas de cobertura, adaptadas às distintas condições agroclimáticas, colaboram com a manutenção da biodiversidade e a diversificação de produtos agrícolas, com a diminuição dos custos, dos riscos ambientais e econômicos e com a manutenção efetiva da sustentabilidade, em qualquer atividade agrícola.

Entretanto, o exemplo de seu uso por diversos autores, faz da utilização da adubação verde associada à espécie Coffea arabica L. ter sido controverso, uma vez que pode não beneficiar, ou até mesmo ser prejudicial. No entanto, algumas literaturas, discorrem que após prejuízos iniciais, acometidos na execução dessa prática, obtiveram-se acréscimos produtivos (FRANCO et al., 1960; FRANCO e LAZZARINI, 1967; LAZZARINI e NEME, 1967; REIS e ARRUDA, 1974; LOMBARDI-NETO et al., 1976; MELLES et al., 1979; REIS e ARRUDA, 1980; SOUZA, 2018).

Dessa forma, a escolha da espécie de adubo verde a ser plantada se torna muito importante, pois cada uma tem características diferentes, como plantio de 
inverno/verão, clima, aporte de massa verde e massa seca, aporte de nitrogênio e manejo como podas. O manejo dos adubos verdes também é muito importante, como a crotalária, o feijão-de-porco e o feijão guandu, são algumas das espécies utilizadas em consórcio, ou mesmo antes do plantio do café, de acordo com a (Figuras 27 e 28).
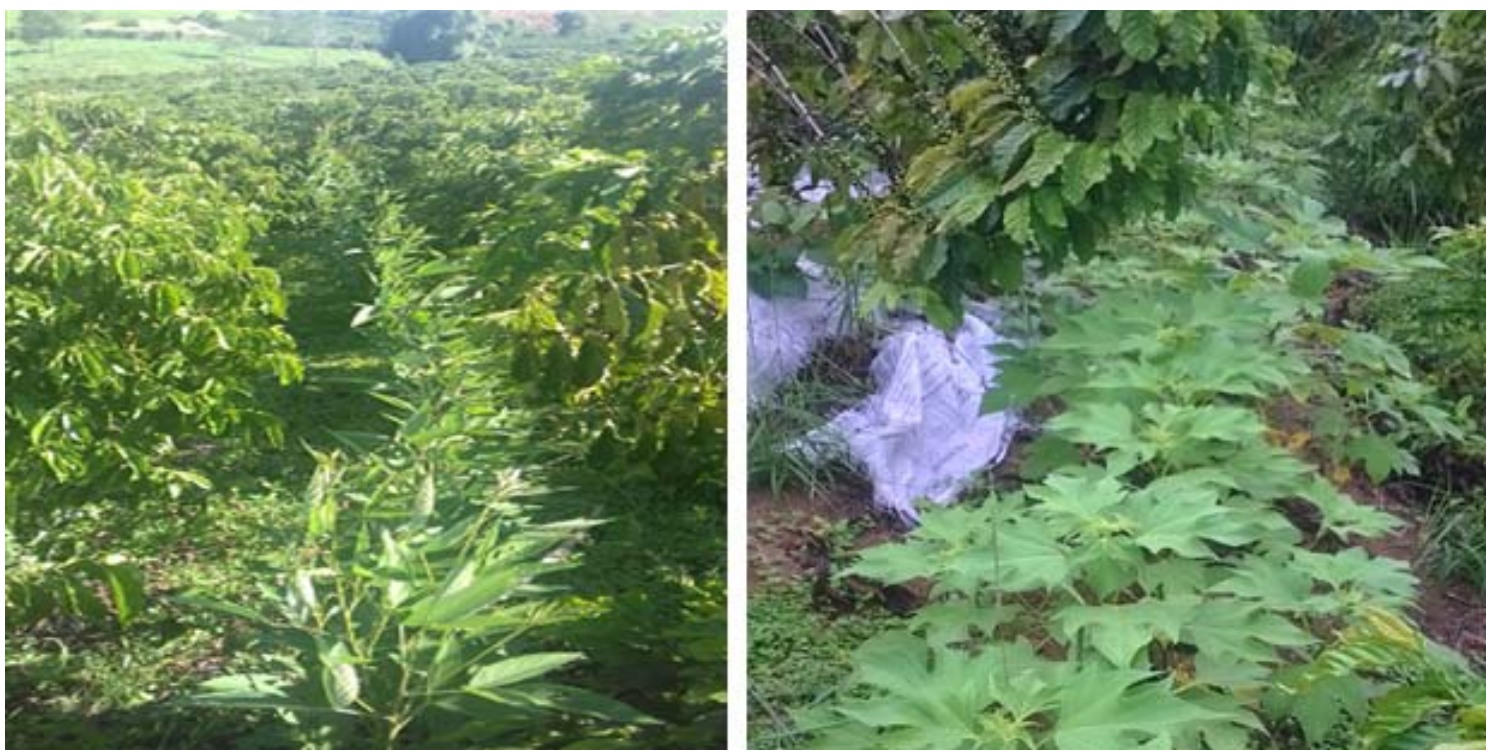

Figuras 27 e 28. Leguminosa em uma lavoura cafeeira.

Algumas espécies utilizadas na cultura do café serão destacadas:

Crotalaria juncea - (Crotalária-juncea) (ANGELETTI et al., 2018).

Tem como principais características e benefícios:

- Promover a fixação biológica de nitrogênio atmosférico no solo;

- Possuir rápida decomposição e mineralização de nitrogênio após o manejo da biomassa;

- Ser eficiente no controle de nematoides;

- Conservar a umidade da camada superior do solo, onde se concentra as raízes das plantas, proteger a insolação.

Será apresentada a matéria seca produzida pela crotalária-juncea (Quadro 1).

Quadro 1. Massa da matéria seca (t/ha) pela crotalária-juncea.

\begin{tabular}{|c|c|c|c|c|c|c|}
\hline ESPÉCIE & $\begin{array}{c}\text { MASSA DA MATÉRIA SECA } \\
(\mathrm{T} / \mathrm{HA})\end{array}$ & $\begin{array}{c}\mathrm{N} \\
(\%)\end{array}$ & $\begin{array}{c}\mathrm{P} \\
(\%)\end{array}$ & $\begin{array}{c}\mathrm{K} \\
(\%)\end{array}$ & $\begin{array}{c}\mathrm{CA} \\
(\%)\end{array}$ & $\begin{array}{c}\mathrm{MG} \\
(\%)\end{array}$ \\
\hline $\begin{array}{c}\text { CROTALÁRIA- } \\
\text { JUNCEA }\end{array}$ & $7,51-9,36$ & 1,38 & 0,23 & 1,24 & 0,96 & 0,55 \\
\hline
\end{tabular}

Fonte: ANGELETTI et al., 2018.

CUIDADOS: Podar e, ou, incorporar quando a planta estiver florida - pela maior produção de massa e para evitar a produção de sementes que poderão competir com o cafeeiro. 
Tithonia diversifolia - (Margaridão mexicano) (LOPES, 2000)

Tem como principais características e benefícios:

- Promover a fixação biológica de nitrogênio atmosférico no solo;

- Exercer função alelopática;

- Possuir rápida decomposição e mineralização de nitrogênio após o manejo da biomassa;

- Ter ação nematicida - T. diversifolia vem sendo estudada sobre sua ação nematicida. Já existem estudos que apontam redução na eclosão de Meloidogyneincognita em 92,48\%, utilizando-se extrato de T. diversifolia;

- Ter potencial de extração do fósforo contido nas partículas do solo.

- Conservar a umidade da camada superior do solo: a cobertura verde ajuda onde se concentram as raízes das plantas, bem como protegê-las contra extremos de temperatura e excesso de insolação.

CUIDADOS: Podar e, ou, incorporar quando a planta estiver florida - pela maior produção de massa e para evitar a produção de sementes que poderão competir com o cafeeiro.

Será apresentada a matéria seca produzida pelo feijão-de-porco (Quadro 2).

Quadro 2. Massa da matéria seca (t/ha) pelo feijão-de-porco.

\begin{tabular}{|c|c|c|c|c|c|c|}
\hline ESPÉCIE & $\begin{array}{c}\text { MASSA DA MATÉRIA SECA } \\
(\mathrm{T} / \mathrm{HA})\end{array}$ & $\begin{array}{c}\mathrm{N} \\
(\%)\end{array}$ & $\begin{array}{c}\mathrm{P} \\
(\%)\end{array}$ & $\begin{array}{c}\mathrm{K} \\
(\%)\end{array}$ & $\begin{array}{c}\text { CA } \\
(\%)\end{array}$ & $\begin{array}{c}\text { MG } \\
(\%)\end{array}$ \\
\hline $\begin{array}{c}\text { FEIJÃO-DE- } \\
\text { PORCO }\end{array}$ & 6 & 3,5 & 0,37 & 4,1 & 1,71 & 0,63 \\
\hline
\end{tabular}

Fonte: LOPES, 2000.

Cajanus cajan - (Feijão-Guandu) (RAMOS, 1994)

Tem como principais características e benefícios:

- Promover a fixação biológica no solo.

- Possuir rápida decomposição e mineralização de nitrogênio após o manejo da biomassa.

- Exercer como subsolador biológico, rompendo com suas raízes as camadas compactas do solo.

- Promover exsudação radicular: são responsáveis pela solubilização e disponibilização do fósforo combinado com o ferro.

- Obter a cobertura verde ajuda conservar a umidade da camada superior do solo, onde se concentra as raízes das plantas, proteger a insolação.

- Ter sistema radicular rigoroso.

- Funcionar como quebra-vento e proteção de mudas contra a insolação.

- Ser má hospedeira de alguns nematoides (meloidogyne).

- Apresentar rapidez na cobertura do solo.

- Controlar plantas espontâneas.

Será apresentada a matéria seca produzida pelo feijão guandu (Quadro 3). 
Quadro 3. Massa da matéria seca (t/ha) do feijão guandu.

\begin{tabular}{|c|c|c|c|c|c|c|}
\hline \multirow{2}{*}{ ESPÉCIE } & $\begin{array}{c}\text { MASSA DA MATÉRIA SECA } \\
(\mathrm{T} / \mathrm{HA})\end{array}$ & $\begin{array}{c}\mathrm{N} \\
(\%)\end{array}$ & $\begin{array}{c}\mathrm{P} \\
(\%)\end{array}$ & $\begin{array}{c}\mathrm{K} \\
(\%)\end{array}$ & $\begin{array}{c}\text { CA } \\
(\%)\end{array}$ & $\begin{array}{c}\text { MG } \\
(\%)\end{array}$ \\
\hline FEIJÃO GUANDU & $4,68-4,82$ & 1,84 & 0,27 & 2,95 & 0,84 & 0,37 \\
\hline
\end{tabular}

Fonte: RAMOS, 1994.

CUIDADOS: Podar e, ou, incorporar quando a planta estiver florida - pela maior produção de massa e para evitar a produção de sementes que poderão competir com o cafeeiro.

Em termos nutricionais, a cultura cafeeira se apresenta como uma das mais exigentes. De acordo coma produção, pode extrair altas quantidades de macronutrientes por ano, principalmente nitrogênio e potássio. Outros elementos, tais como cálcio, magnésio, fósforo, enxofre e os micronutrientes, são absorvidos em menores quantidades (FERRÃO et al., 2012).

O uso da adubação verde vem como uma boa opção para melhorar a parte nutricional do solo. Além desse benefício, promover a cobertura de solo, ser uma excelente opção de rotação de cultura, melhorar a estrutura do solo, aumentar a matéria orgânica, fornecer $\mathrm{N}$ para as plantas de interesse econômico, via simbiose com algumas bactérias, estimular o desenvolvimento da microbiota do solo, além de conservar a sua umidade.

\subsection{Quebra-vento e, ou, cercas vivas}

As "Cercas-vivas" e os "Quebra-ventos" têm funções semelhantes na cafeicultura:

- Cercas vivas: são fileiras de árvores altas, de folhagem densa, que se planta contornando uma propriedade agrícola para proteção de ventos externos.

- Quebra-ventos: são fileiras de árvores altas plantadas ao redor de talhões visando proteger de ventos fortes que afetam a plantação de diversas formas: injúrias em folhas e frutos, diminuição de umidade, controle de geadas, e principalmente, para o nosso caso de manejo de pragas, diminuição de infestação de pragas e doenças que são trazidas na corrente de vento por imigração.

Assim, o quebra-vento é uma barreira vegetal usada para proteger as plantas contra a ação de ventos fortes, além de proporcionar um ambiente favorável à produtividade das lavouras e dos animais. O objetivo principal do quebra-vento é reduzir a velocidade do vento (CONCEIÇÃO, 1996; FRANÇA e OLIVEIRA, 2010).

A indicação de uma dada espécie deve considerar o fato de que seja a que mais se aproxima da árvore ideal para quebra-ventos, que deve ser: ereta, perenifólia, de rápido crescimento, pouco agressiva na competição radicular e de copa não muito densa.

Quebra-ventos arbóreos são definidos como barreiras constituídas de renques de árvores dispostos em direção perpendicular aos ventos dominantes. Essas barreiras são plantadas principalmente com a finalidade de reduzir a velocidade do vento e, 
assim, melhorar as condições ambientais para o desenvolvimento das culturas (SOUZA, 2018).

Para maximização dos seus efeitos benéficos, os quebra-ventos devem ser bem planejados antes de sua implantação, obedecendo aos seguintes requisitos básicos (CONCEIÇÃO, 1996; FRANÇA e OLIVEIRA, 2010):

- Analisar a direção do vento e definir a localização dos quebra-ventos;

- Fazer a barreira perpendicular à direção do vento para a proteção dos cultivos;

- A altura deve ser duas a três vezes mais altas do que o cultivo a ser protegido;

- A razão comprimento/altura deve ser no mínimo 20:1 para uma adequada redução da velocidade do vento;

- Preferencialmente, utilizar árvores ou espécies de diferentes alturas, partindo da menor para a maior, de tal forma a direcionar o vento para camadas superiores; e

- A densidade deve ser de 30 a $40 \%$ de penetrabilidade do vento.

Na Figura 29, observam-se bananeiras atuando na função de quebra-vento.

O foco de medidas devem ser as áreas problemáticas, que sofrem com ventos frios continuados, evitando prejuízos diretos e indiretos sobre a plantação do cafezal, principalmente nas plantas mais novas: são as mais prejudicadas pelo vento. Para a cultura cafeeira, recomenda-se a utilização de plantas como a crotalária para cafés novos, e deve ser feita com renques plantados a cada 3-4 ruas do cafezal, desde o plantio até o segundo ano da lavoura (OLIVEIRA, 2009). Para lavouras adultas na região serrana do Espírito Santo, tem-se utilizada árvores, tais como: eucalipto e frutíferas (abacate, tangerina ponkan e banana).

Segundo esse mesmo autor, estas barreiras são muitos importantes para evitar danos físicos para áreas foliares, dessecação dos solos, disseminação de pragas e doenças, evitar o ataque da cercosporiose e phoma, também muito importante para evitar a disseminação do ácaro e ferrugem no cafeeiro. Em épocas de floração, os ventos podem ser altamente danosos, havendo perdas significativas na produção do ano seguinte.

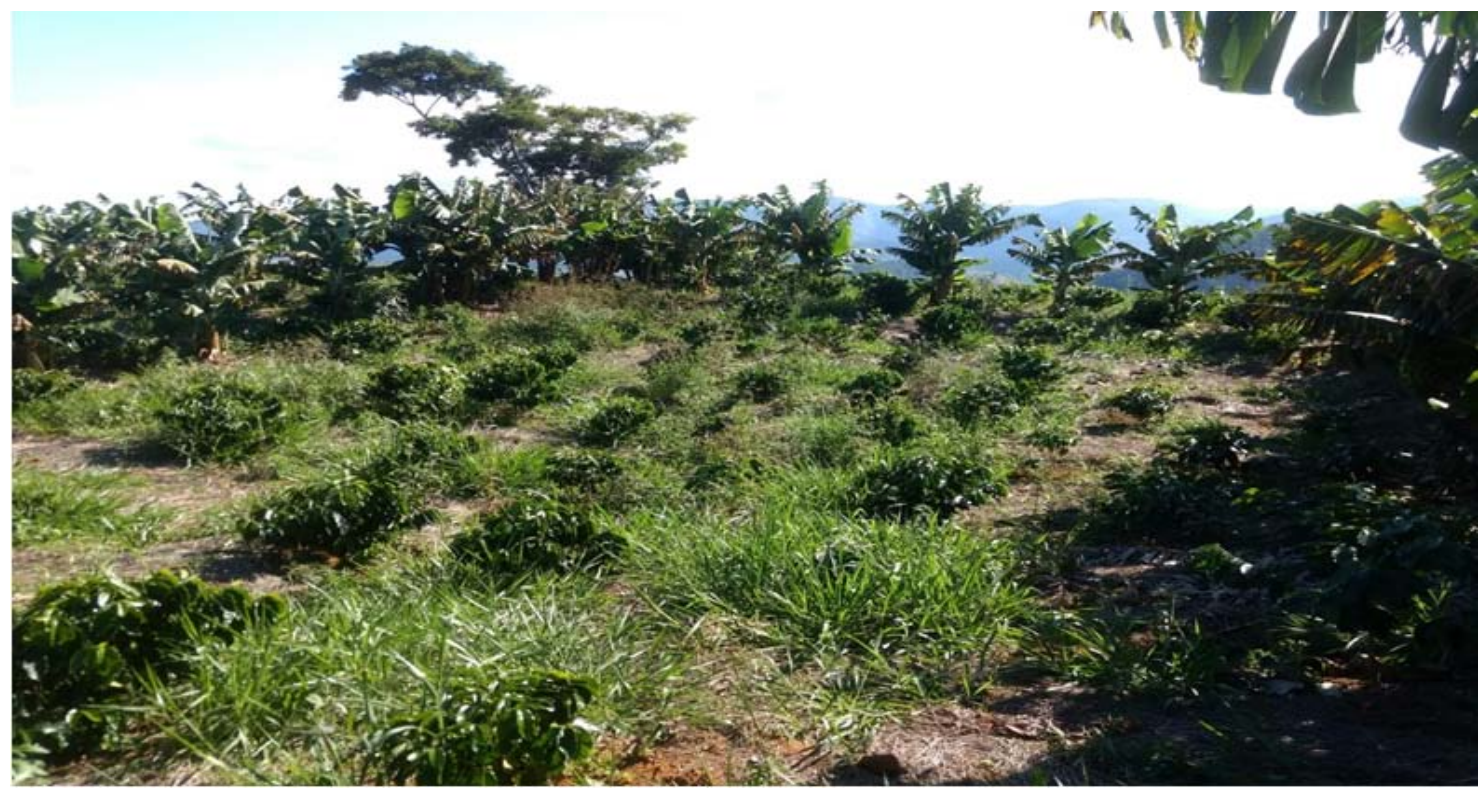

Figura 29. Bananeiras funcionando como quebra-vento. 


\subsection{Manejo do mato}

O mato presente na cultura do café, contrariamente do que se pensava em tempos passados, é bastante favorável para o ambiente do agroecossistema café. Contribui para: aumento da umidade; diminuição da temperatura; favorecimento à microfauna do solo; promove boas condições para fungos patogênicos e fungos parasitoides de pragas que atacam o cafeeiro; auxilia no aumento de matéria vegetal, tais como: teores de matéria orgânica e ajuda na ciclagem dos nutrientes, deixando-os acessíveis à planta. Acima de tudo, contribui para atração de insetos de controle biológico, principalmente da ordem himenóptera, que abrange vespas e marimbondos, que promovem o controle do bicho-mineiro e ácaros, entre outros (VENTURA et al., 2007; ZACARIAS et al., 2019).

Assim, o "mato" se tornou um aliado importante na conservação do solo e água e na fertilidade do solo, melhorando a produtividade das lavouras cafeeiras: o termo controle de mato já não é tanto usado entre os agricultores. Alguns diziam que o ideal seria os cafezais ficarem "no limpo", para não haver competição de nutrientes, com isso havia uso constantes de enxadas, grades, rotativas, deixando o solo exposta ao sol e à erosão (Figura 30).

Atualmente, o "Controle do Mato" vem sendo substituído pela técnica "Manejo do Mato", que se concentra em dois pilares: manter a linha do café sem plantas daninhas vivas, mas coberta por palhada; e a entrelinha sempre com mato - quanto mais mato se produzir, melhor. A ideia é produzir mato na entrelinha para colocá-lo na linha do café formando um "colchão" de material vegetal morto (Figura 31).

Com isso, a linha do café permanece sempre coberta por palhada e a entrelinha por plantas daninhas crescendo e sendo continuamente roçadas, repondo nutrientes anteriormente perdidos por erosão superficial no solo exposto: agora são aproveitados pelo mato e devolvidos ao café em forma de matéria orgânica (CAFEPOINT, 2020).

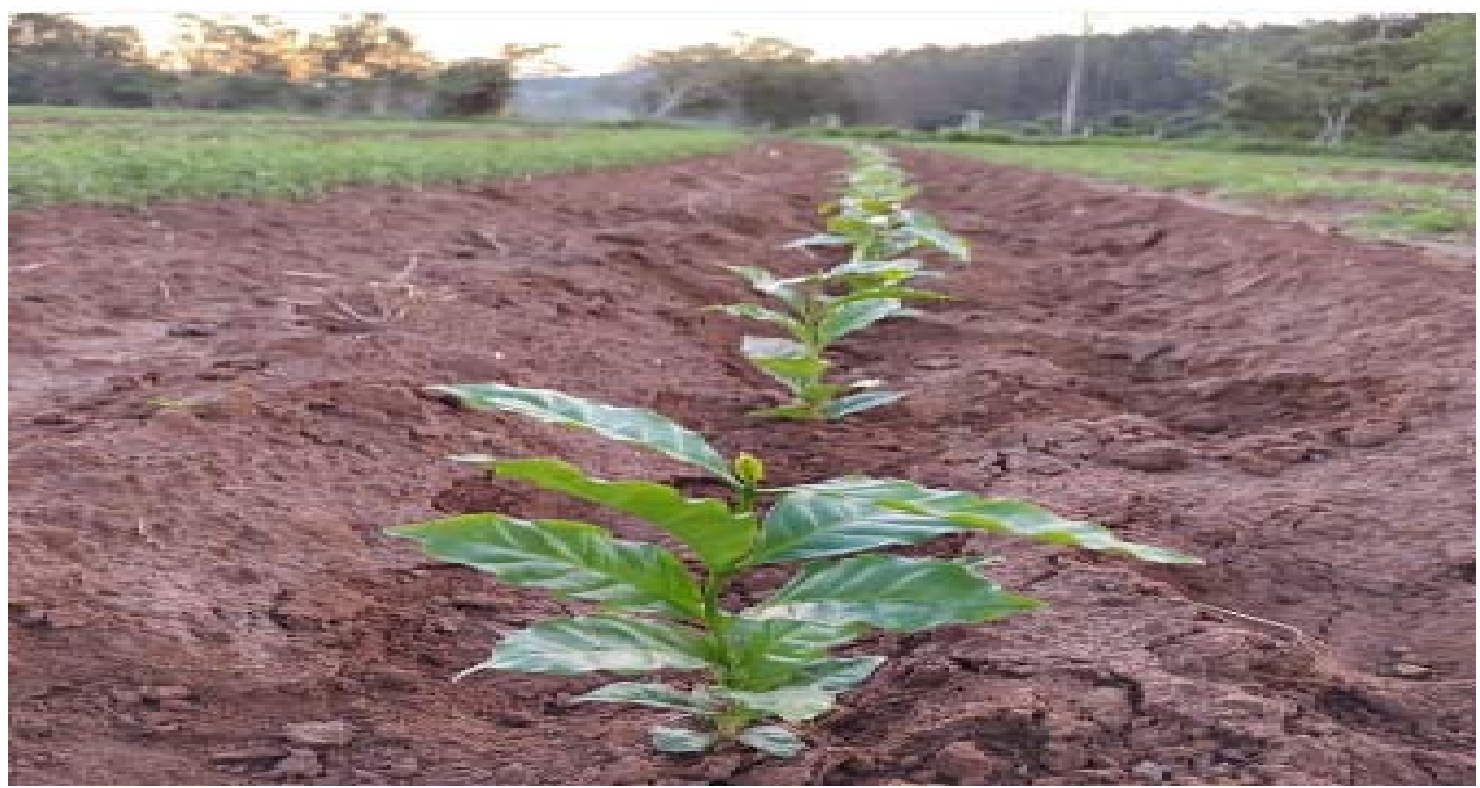

Figura 30. Lavoura cafeeira recém-implantada com braquiária nas ruas. Fonte: CAFEPOINT, 2020. 
Este manejo nas entrelinhas há alguns anos era proibida, pois era conhecido como competidor de nutrientes e água com o cafeeiro. Em contrapartida, novas técnicas foram se aperfeiçoando e a utilização do mato na linha do café se torna algo preciso para melhorar a produção e primordial à sustentabilidade do meio explorada à produção de café.

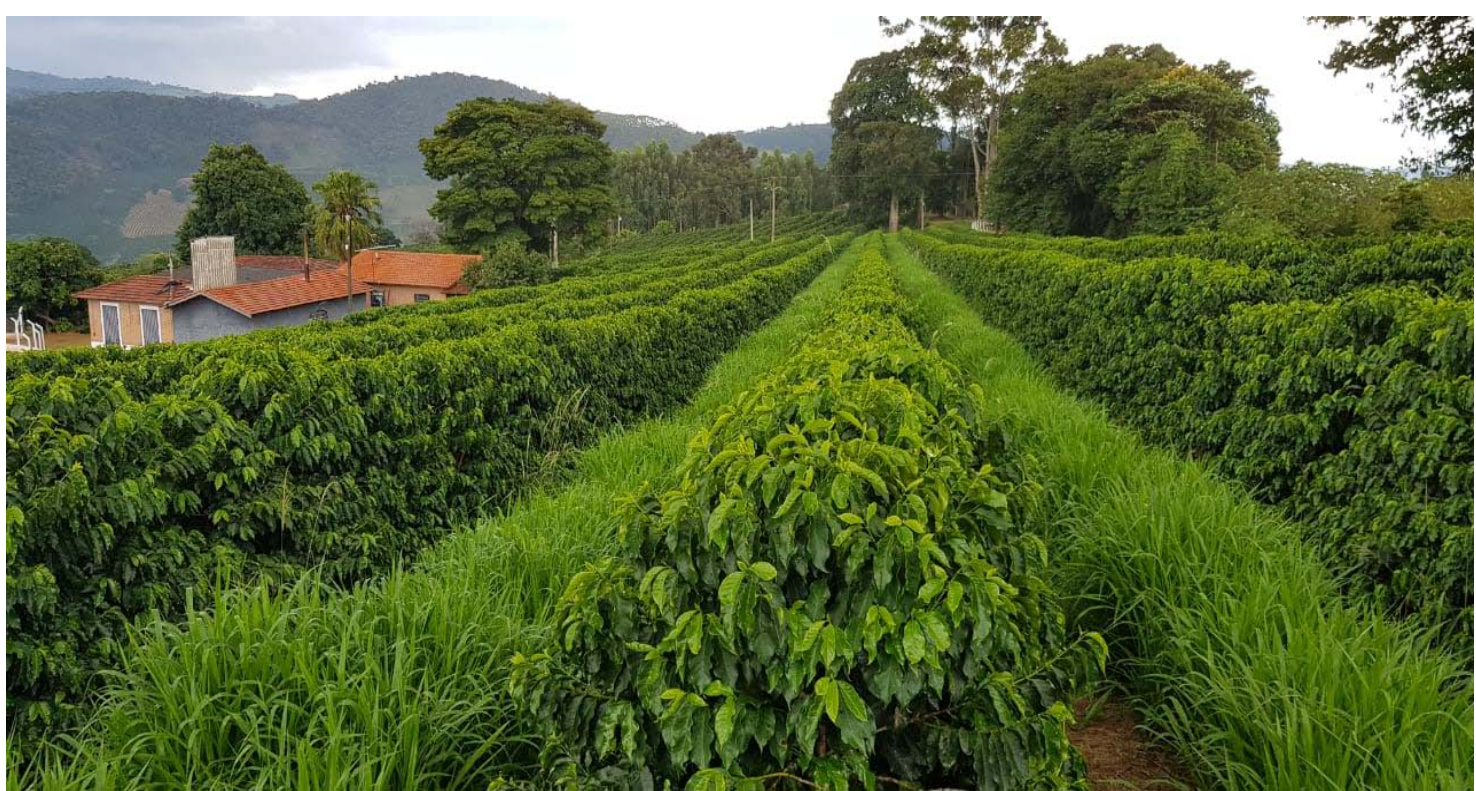

Figura 31. Mato nas entrelinhas do cafezal da fazenda do Sistema APRomero, em São Roque de Minas.

De acordo com Zacarias et al. (2019), o mato ajuda na cobertura vegetal e a decomposição da matéria orgânica é disponibilizada às plantas em forma de nutriente pelo processo de ciclagem, realizado por microrganismos no solo (Figura 32).

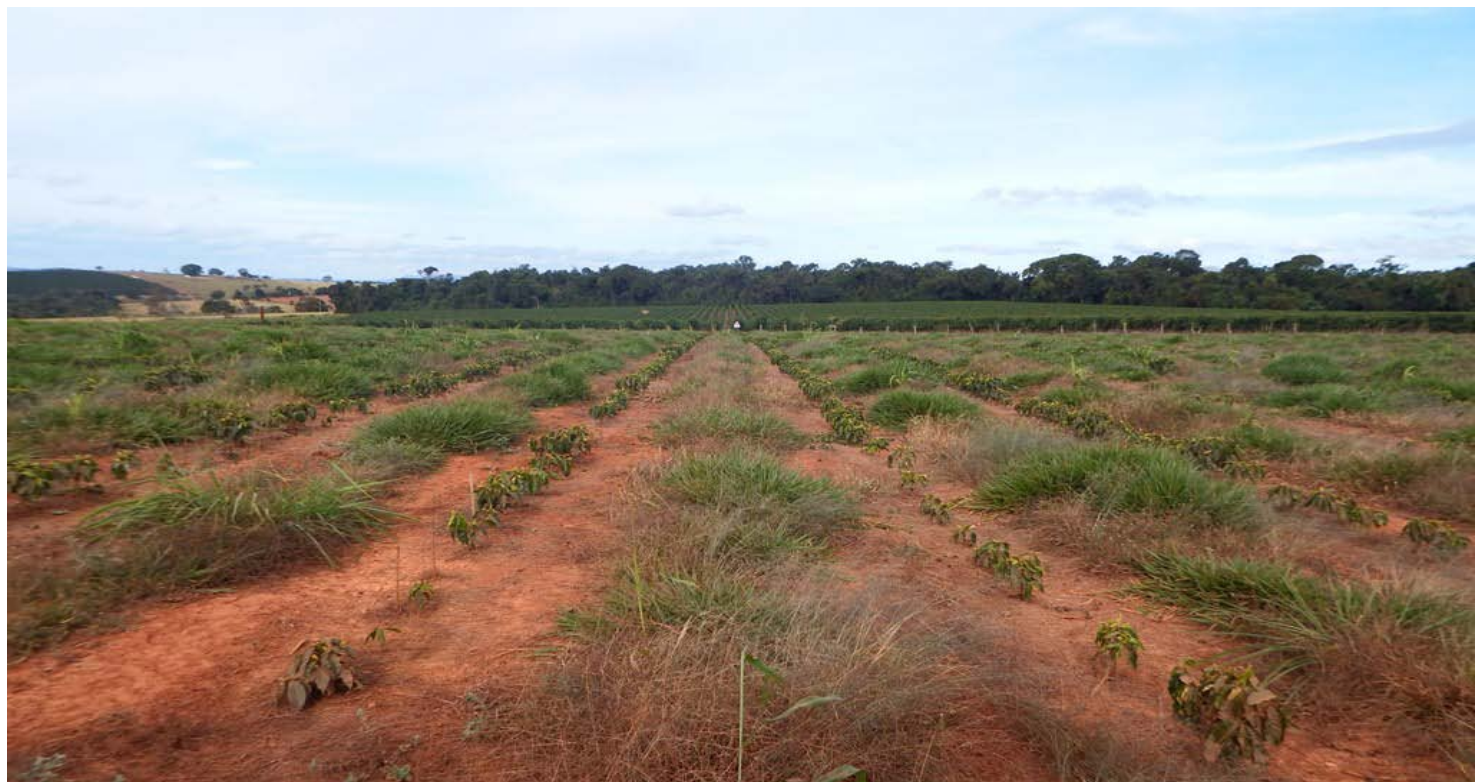

Figura 32. Manejo do mato nas entrelinhas do cafezal em fazenda do Grupo A P Agrícola (Sistema APRomero), em São Roque de Minas. 
Também, funciona como alojamento de inimigos naturais que combatem as pragas e doenças prejudiciais ao cafeeiro, aumento da umidade do solo, amortecimento da água da chuva evitando erosão e favorecendo a sua infiltração no solo, consequentemente, elevando os níveis do lençol freático e disponibilizando água à cultura. Contudo, há de se considerar, as técnicas deixam evidente que o mato não pode crescer espontaneamente, há que se faça o manejo adequado por meio de roçadas evitando que cresça próximo à saia do cafeeiro, fator que favoreceria a competição do mato ao café (Figura 33).

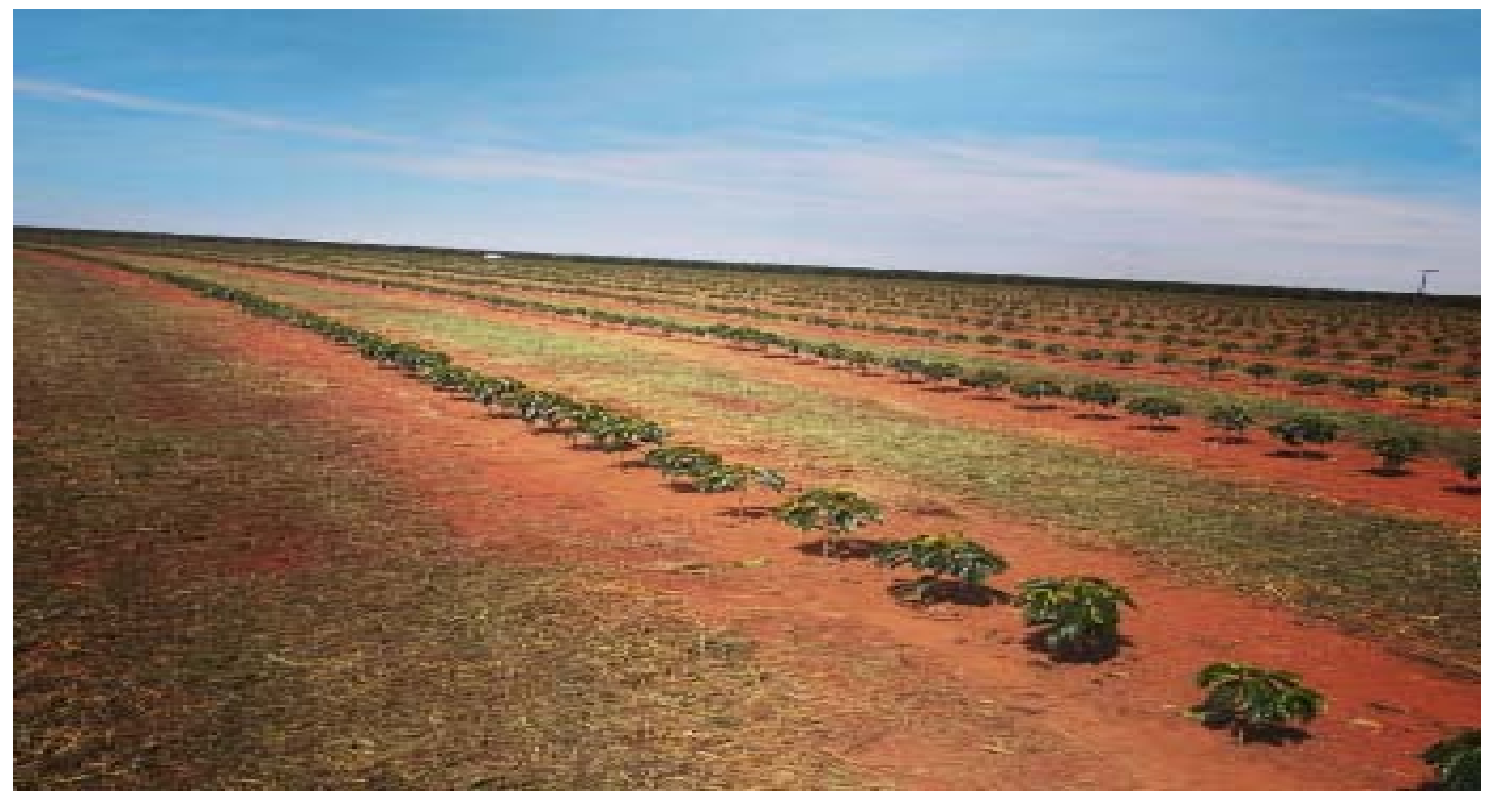

Figura 33. Manejo do mato nas entrelinhas do cafezal em uma das fazendas do Sistema A P Agrícola (APRomero), em São Roque de Minas.

De modo geral, seja qual for o manejo agrícola que seja aplicado, desde que seja o correto, é favorável à cultura. Contudo, é necessário sempre buscar o equilíbrio entre produção e preservação, aonde ambos irão se manterem em vantagem. No entanto, historicamente, a técnica do manejo do mato não era permitida, pois era tido como competição para as plantas de café, em relação aos nutrientes e água. Desde que o manejo mantenha o mato abaixo da saia do cafeeiro, que irá evitar a competição natural, pode-se manter algum mato na área (SOUZA, 2015; MESQUITA et al., 2016).

Há de se considerar que a linha do café deve permanecer sempre coberta por palhada ou mulching (Figura 34) e a entrelinha por plantas cultivadas, ou mesmo espontâneas, crescendo e sendo continuamente roçadas (Figura 35), repondo nutrientes anteriormente perdidos por erosão superficial no solo exposto: agora são aproveitados pelo mato e devolvidos ao café em forma de matéria orgânica (Revista CAFEPOINT, 2020).

As palhadas têm o papel de inibir a crescimento das ervas daninhas, nas linhas do café, com o abafamento das sementes impedindo a germinação. O solo melhora a sua estrutura física, química e biológica, aumenta a porosidade, estrutura o solo, aumenta a fertilidade e a retenção de água, além de majorar a microbiota do solo. Com o manejo do mato nas linhas também diminui a temperatura do solo: o solo exposto ao sol pode atingir temperaturas de até $65^{\circ} \mathrm{C}$, ocorrendo a morte das radicelas que são responsáveis pela absorção de nutrientes. Em solos cobertos, esta temperatura fica em torno de $40^{\circ}$ a $45^{\circ} \mathrm{C}$. Solos cobertos (Figura 36) diminuem as perdas causadas por erosão, aumenta o armazenamento de água no solo e aumenta a ciclagem de 
nutrientes (Revista CAFEPOINT, 2020). Na produção orgânica e, ou, agroecológica, não é permitida a utilização de defensivos agrícolas, visto que ele é inadequado para o organismo humano pela sua toxidez, provocando doenças crônicas tanto ao produtor quanto ao consumidor (FERRÃO et al., 2012).

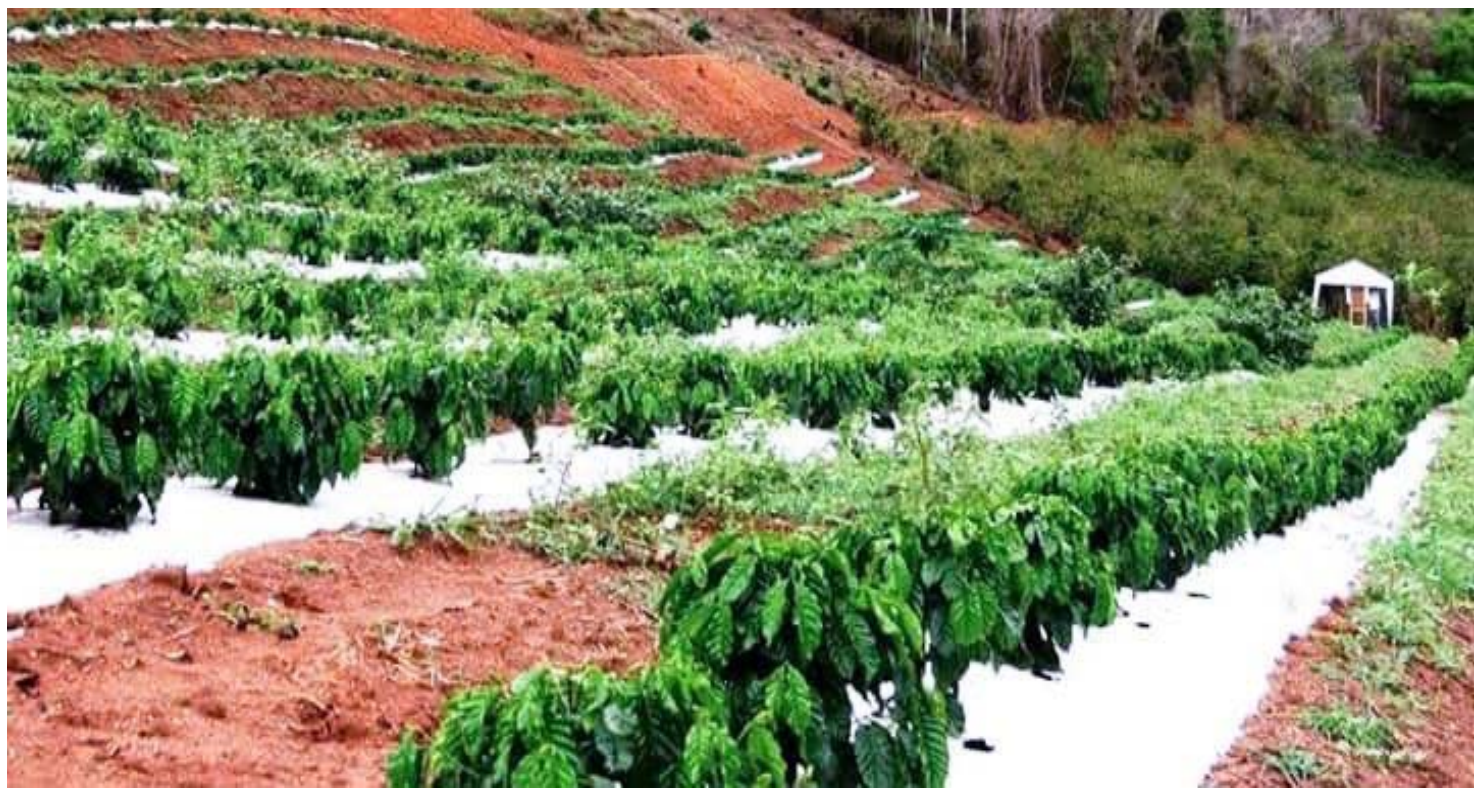

Figura 34. Linha do cafeeiro coberta por palhada (mulching). Fonte: Revista CAFEPOINT, 2020.

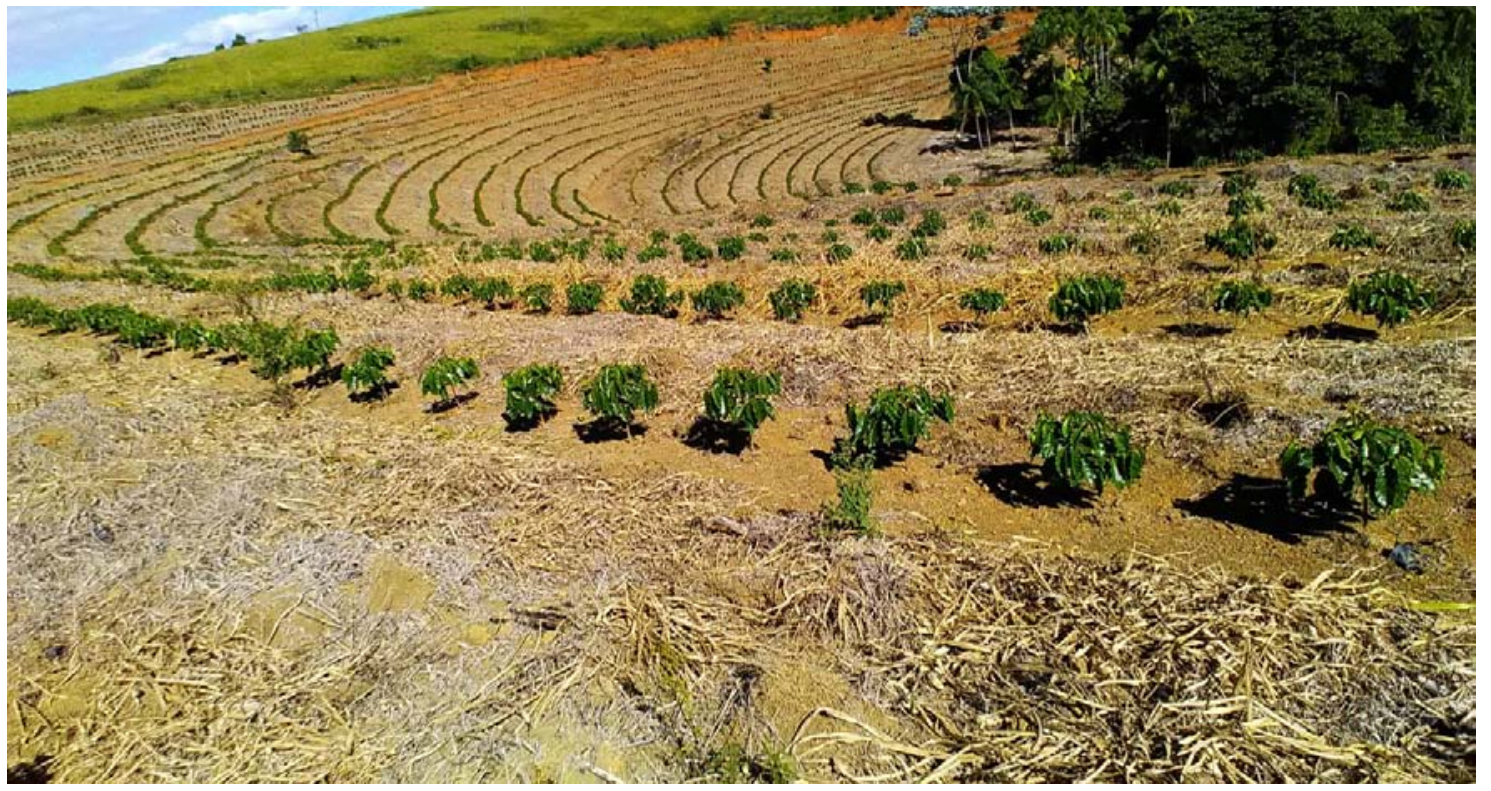

Figura 35. Linha do cafeeiro coberta por palhada (compostagem laminar). Fonte: Revista CAFEPOINT, 2020. 


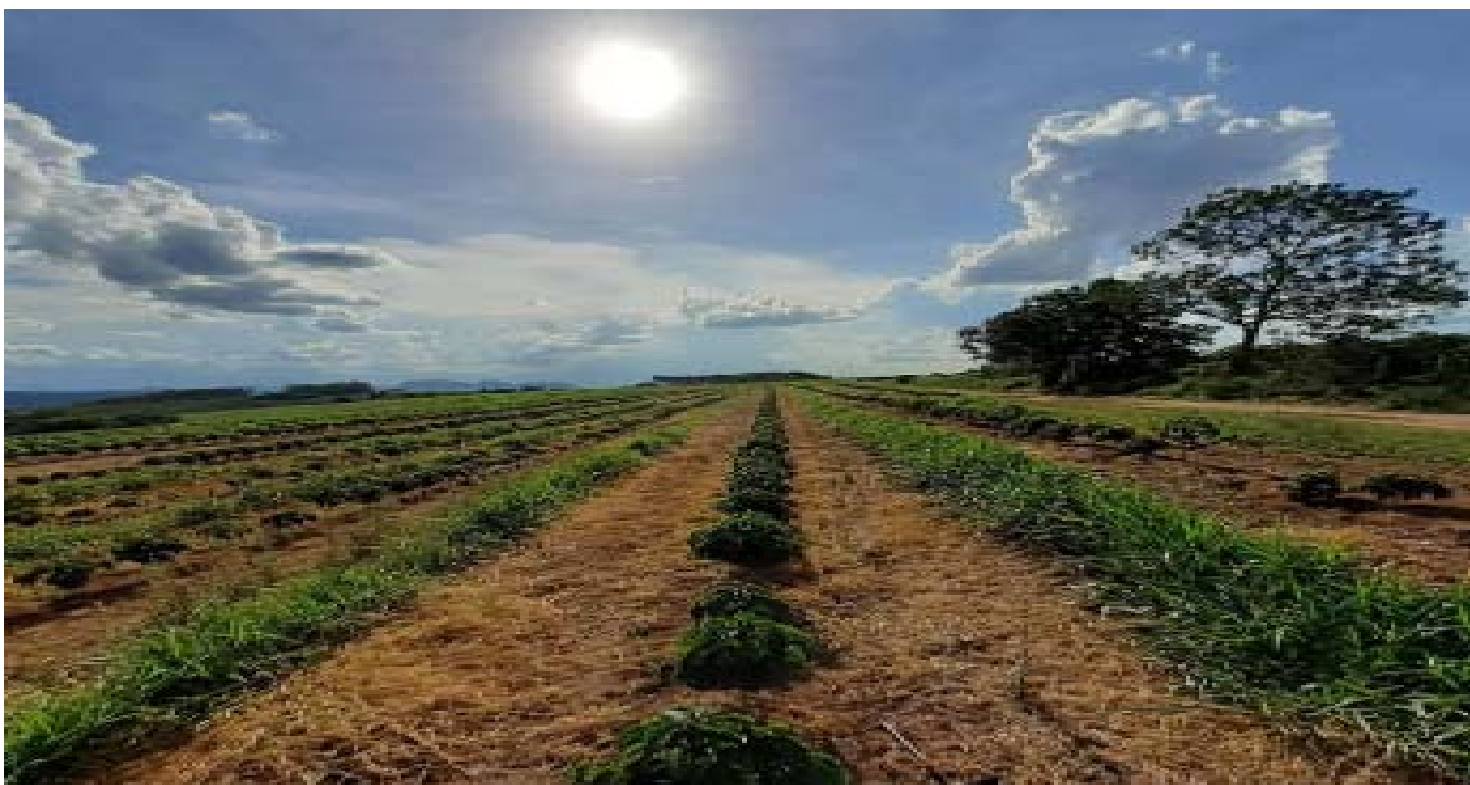

Figura 36. Ruas com braquiária e linha do cafeeiro com "compostagem laminar".

COMPOSTAGEM LAMINAR: alternativa para o aproveitamento de resíduos orgânicos.

A compostagem laminar foi inspirada nos processos naturais, mais propriamente a degradação da serapilheira nas matas. Como o material é depositado sobre o solo, todos os processos fermentativos são aeróbicos, sendo criado um ambiente propício para o desenvolvimento da fauna edáfica, como minhocas, colêmbolos, ácaros, insetos diversos e principalmente a microvida, como fungos, bactérias e actinomicetos, que tem a capacidade de degradar a matéria orgânica retirando nitrogênio da atmosfera, o qual ficará disponível para as plantas (EMBRAPA, 2018).

\subsection{Sistemas agroecológicos de produção}

Atualmente, a cafeicultura orgânica e, ou, agroecológica é de suma importância: sabese o impacto da cafeicultura convencional aos aspectos ambientais. O café convencional está entre os alimentos quimicamente mais tratados no mundo. Usam-se fertilizantes sintéticos, herbicidas, fungicidas, acaricidas e inseticidas. Os agricultores estão expostos a um alto nível de produtos químicos ao pulverizar as lavouras e ao manipulá-las durante a colheita.

No caso do café orgânico, não há fertilizantes sintéticos ou produtos químicos usados no cultivo ou produção: significam grãos, ar, terra e água mais limpos. Nesse sistema, o café é cultivado apenas com fertilizantes orgânicos, como polpa de café, esterco de galinha ou composto, não promovendo o desmatamento. $\mathrm{Na}$ verdade, ajuda na conservação da vida selvagem, aves, vegetação e prevenção da erosão e doenças do solo. A vegetação natural retém e aumenta a fertilização natural do solo (Figura 37).

Os nutrientes do solo são retidos e reabastecidos naturalmente para uma agricultura sustentável que continuará produzindo ano após ano. Em Minas Gerais, a região do Caparaó merece destaque por suas lavouras exuberantes. O Sítio do Vovô Nininho, em Pedra Menina, traz um exemplo de lavoura orgânica admirável (Figura 38). 


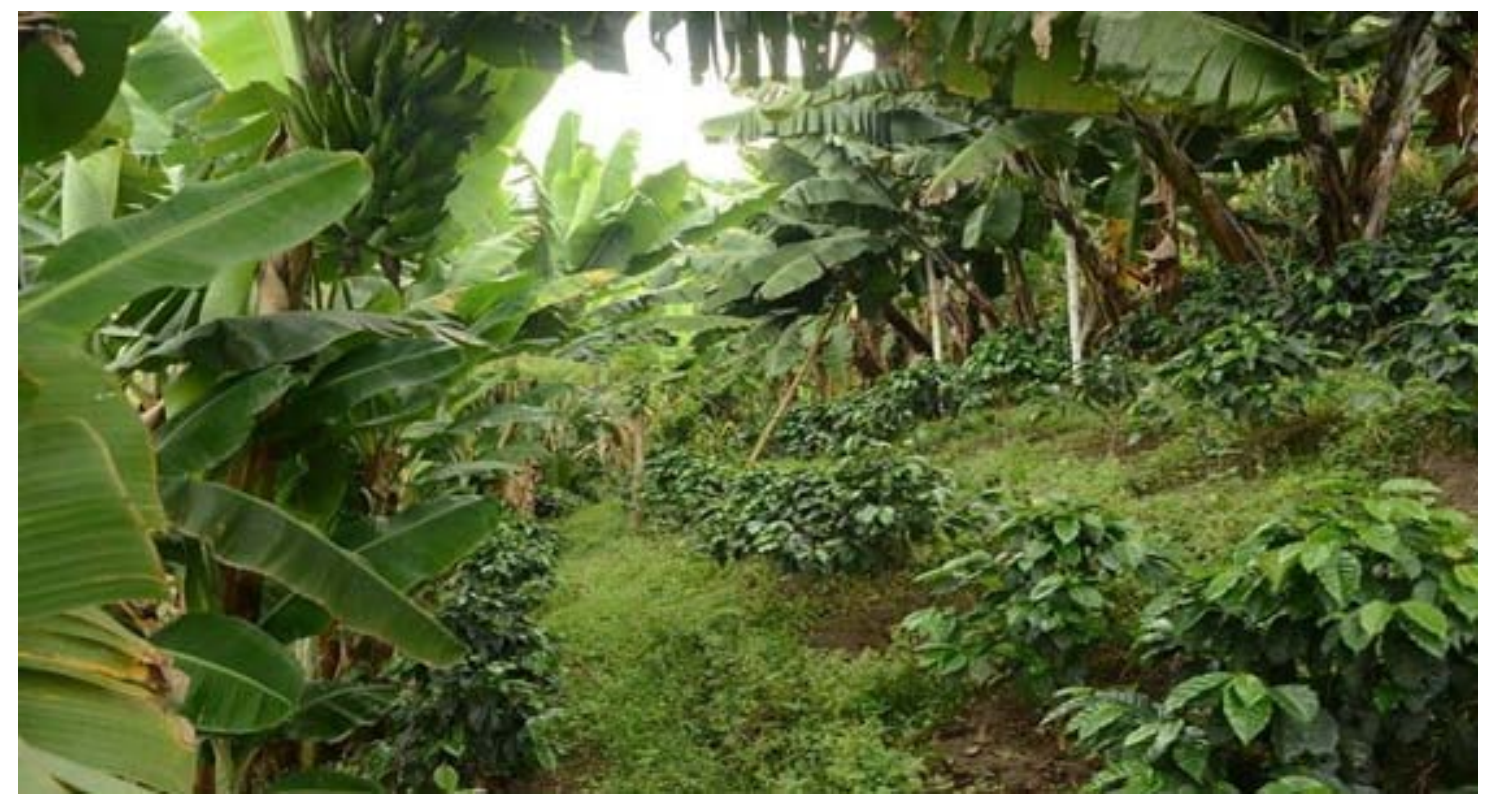

Figura 37. Cultivo de café orgânico e agroecológico (sistema diversificado). Fonte: LOPES, 2012.

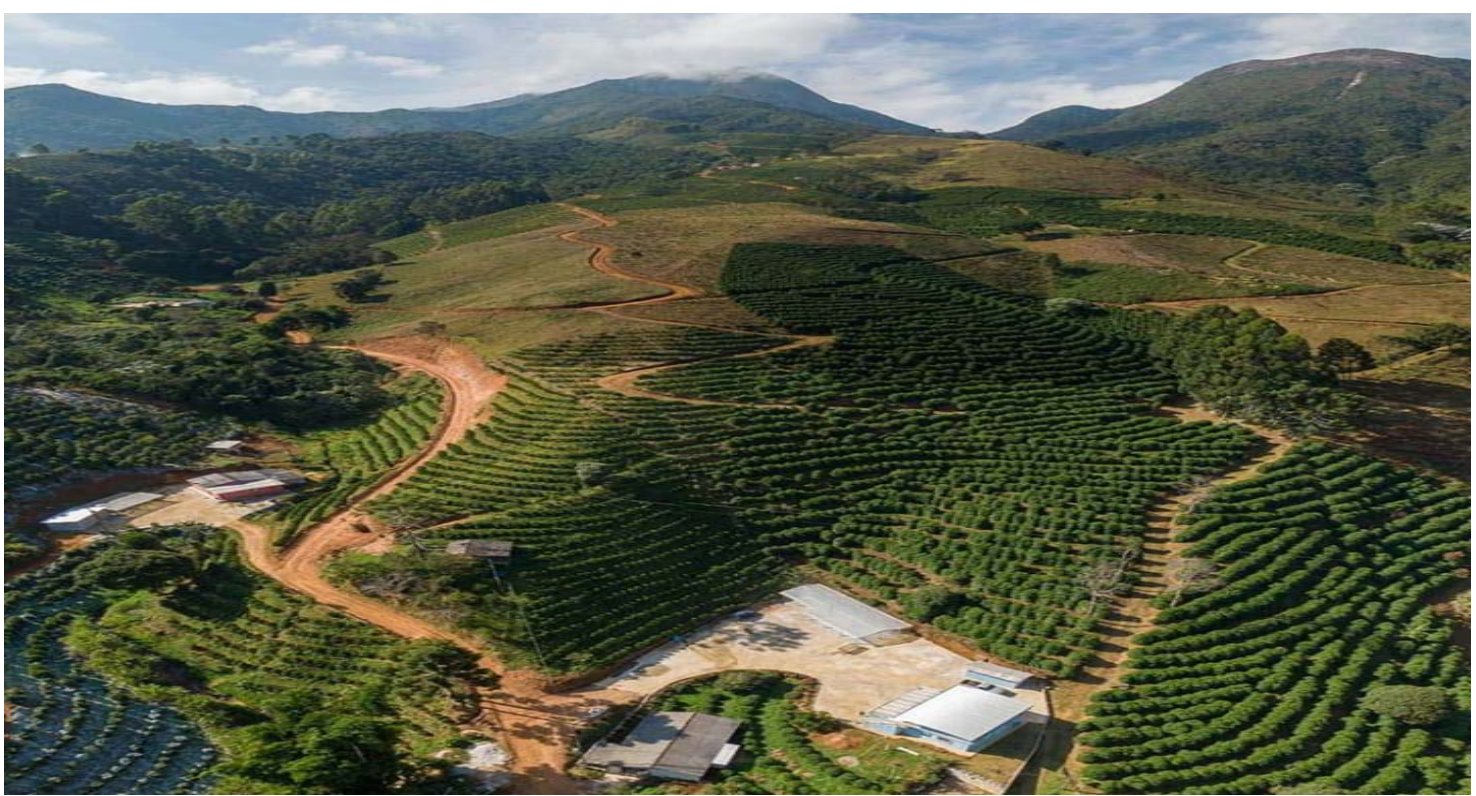

Figura 38. Lavoura de café orgânico no Sítio do Vovô Nininho em Pedra Menina, MG. Fonte: Sítio do Vovô Nininho, 2020.

Nos dias atuais, um novo fator deve ser considerado: projeções climáticas para o século XXI apontam para um aumento de temperatura e conflitos climáticos extremos. A centralização dos gases de efeito estufa causam alterações nos elementos atmosféricos: se as estimativas de temperatura estiverem corretas, a temperatura média poderá aumentar entre $1^{\circ} \mathrm{C}$ e $5,8^{\circ} \mathrm{C}$ - estes valores trariam grandes impactos para a atividade de cafeicultura e para os recursos naturais. Discutem-se estratégias para a redução desta vulnerabilidade ambiental, econômica e social; nas quais, o retorno da arborização poderá originar, além de benefícios ecológicos e econômicos, 
uma estabilidade na variabilidade do microclima dos plantios (SOUZA, 2015; SOUZA et al., 2020).

Sabe-se que o cafeeiro pertence ao grupo de plantas C3; ou seja, é uma planta dependente de fatores ambientais, como temperatura e, consequentemente, sombreamento, mais adaptados a ambientes amenos e úmidos, possuindo adaptações fisiológicas e morfológicas para isso (BRAUN et al., 2007; SOUZA et al., 2020). Mais uma vantagem do plantio de café com sombreamento.

Segundo Matiello (1995), em lavouras sombreadas, é nítida a diminuição da desfolha, plantas com maior vigor, proteção contra os ventos, menor ataque do Bicho-mineiro, preservação da biodiversidade, melhor controle térmico dentro da lavoura, proteção contra geadas e altas temperaturas, além da diminuição da bienalidade existente entre as safras sucessivas. Contudo, pesquisas relatam a redução de produção do cafezal em cultivo sombreado, apesar de apresentar, na maioria dos casos, melhor qualidade de bebida. Há de se considerar, entretanto, que a rentabilidade adicional das culturas consorciadas em um Sistema Agroflorestal (SAF) poderá superar essa queda de produtividade.

O SAF é caracterizado por um povoamento de árvores heterogêneas ou cultura agrícola. Este sistema promove vantagens econômicas e ambientais para agricultura familiar justamente por aliar agricultura (agro) com a floresta (florestal) utilizando a mesma de forma sustentável, fazendo com que o produtor dependa cada vez menos de insumos exógenos ao sistema, resultando em maior segurança alimentar e economia: tanto para os agricultores, como para os consumidores (ARMANDO et. al, 2002).

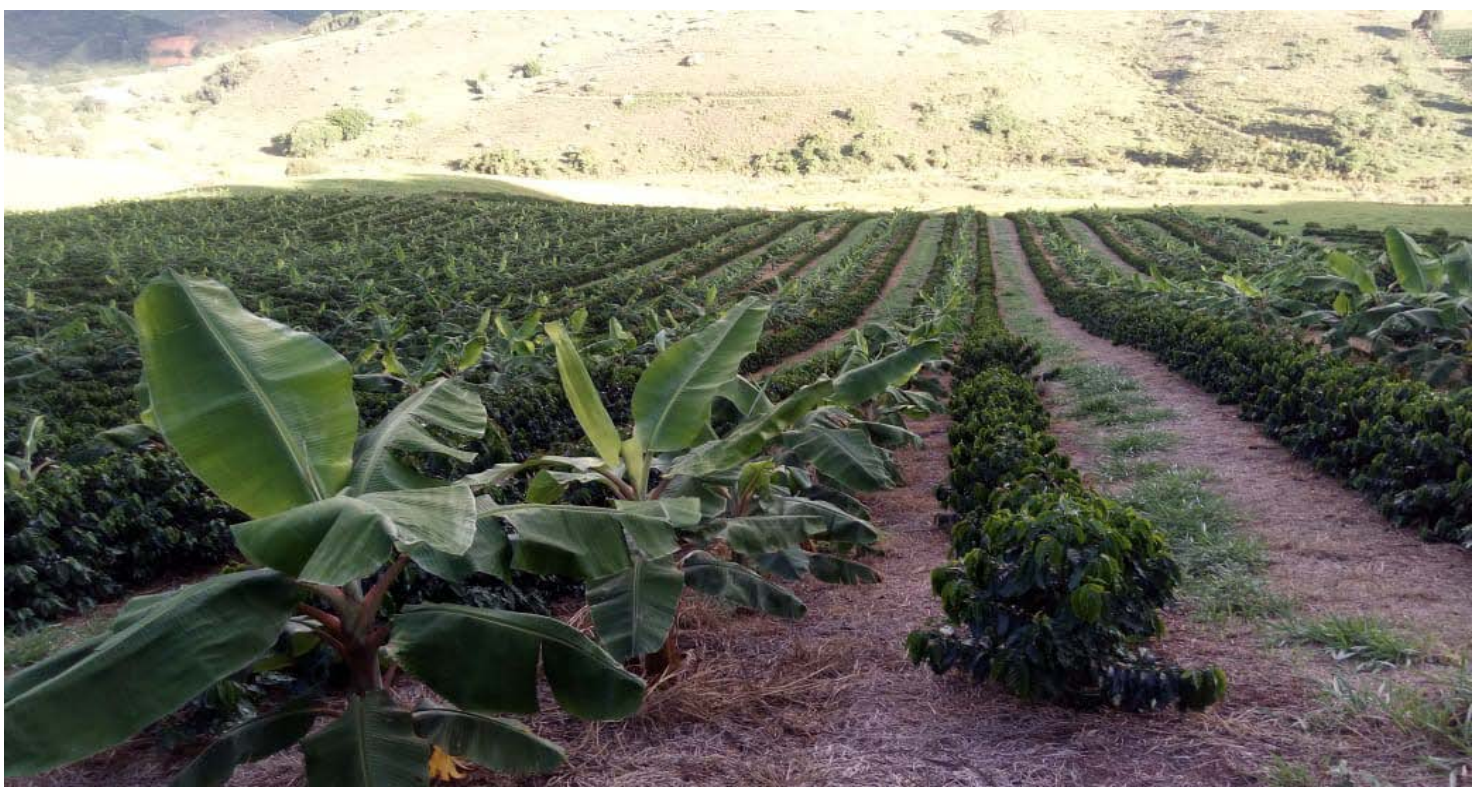

Figura 39. Lavoura de café agroecológica: SAF - café com banana.

Contudo, para a implantação da agrofloresta na unidade produtiva, é importante analisar junto ao produtor as espécies de interesse para comercialização. Também, as plantas que se adaptam melhor as condições climáticas, do ambiente, do solo e aos recursos hídricos da região em que a propriedade está inserida. Nos SAFs é interessante a inserção de plantas de ciclo curto, tais como: culturas anuais, hortaliças, medicinais, ornamentais e frutíferas; e as de ciclo longo, tais como: espécies florestais (Figura 40). O objetivo é manter a comercialização em diferentes épocas do ano, 
proporcionando diversificação da produção e da renda do produtor, bem como melhor aproveitamento da mão de obra familiar (ARMANDO et al., 2002).

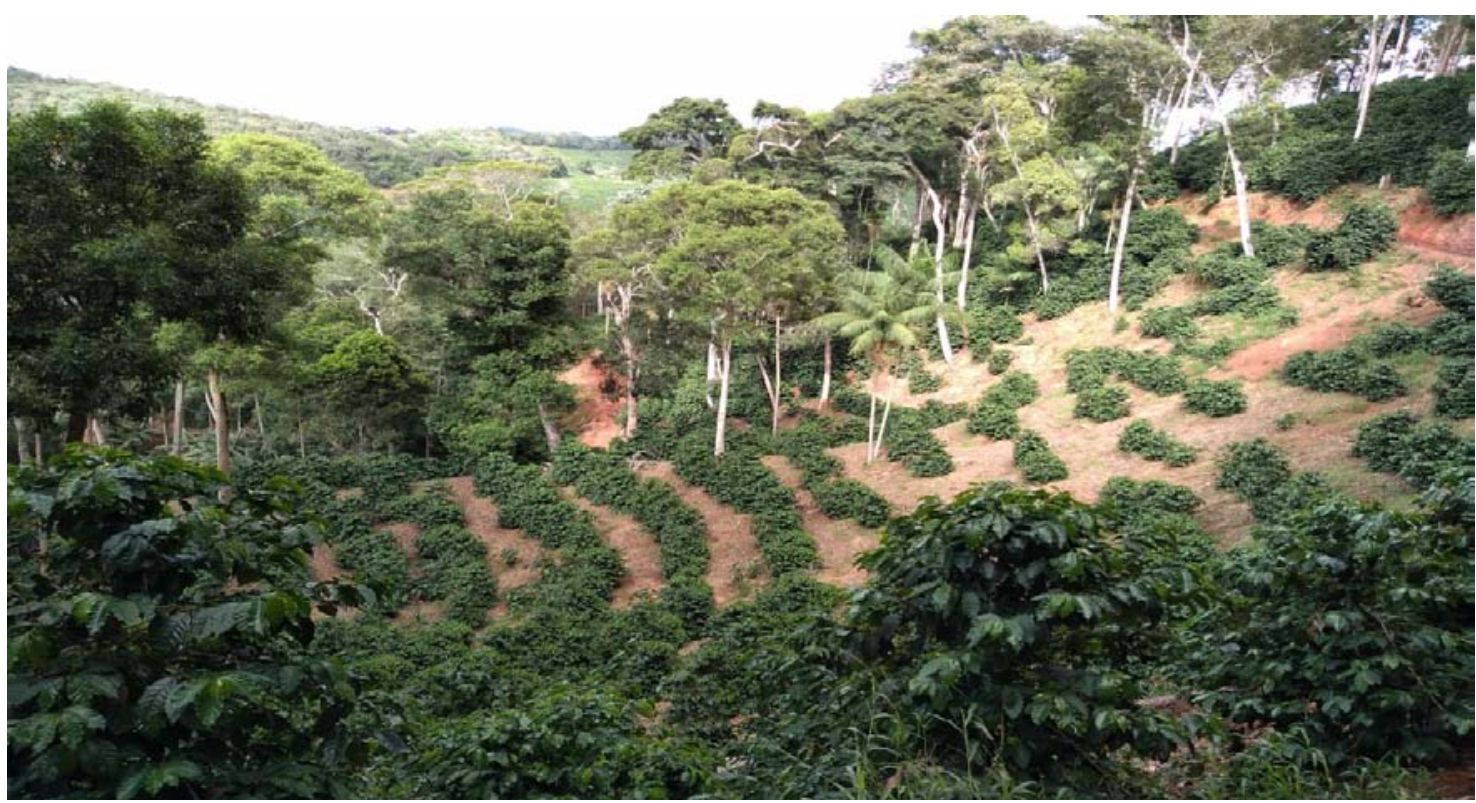

Figura 40. Lavoura de café agroecológica sombreada com espécies nativas.

A ideia de projetar modelos de SAFs, entre outros, é inserir espécies adaptadas à região (espécies nativas) e ao sistema produtivo como forma de contribuição da conservação e, ou, preservação dos biomas brasileiros, bem como incentivar o consumo e o resgate do conhecimento e da cultura dos povos tradicionais daquela região. O desmatamento avança sobre os biomas brasileiros gerando erosão do solo, perda de biodiversidade, de conhecimento, autonomia (dos produtores rurais), insegurança alimentar e outros conflitos aos quais a agrofloresta se propõe mitigar.

Diante deste cenário, a proposta é estabelecer um sistema que favoreça o equilíbrio e harmonia com a natureza, restabelecendo a resistência e a resiliência do agroecossistema, por assemelhar-se ao processo natural de sucessão ecológica. Objetiva também promover metodologias/ferramentas que se enquadre a cada modelo, proporcionados pelo manejo e práticas de conservação do solo. As tecnologias utilizadas devem restaurar a harmonia do sistema, ser eficiente e economicamente rentável para o produtor rural.

\subsection{Pagamento por Serviços Ambientais (PSA)}

O "Pagamento por Serviços Ambientais" - PSA, é um instrumento econômico que busca recompensar todo produtor que, em virtude de suas práticas de conservação, proteção, manejo e recuperação de ecossistemas, mantem ou incrementa o fornecimento de um serviço ecossistêmico (benefícios providos pela natureza). Esses serviços ecossistêmicos incluem, entre outros: a regulação do clima, a manutenção da fertilidade e o controle da erosão dos solos, o armazenamento de carbono, a ciclagem de nutrientes, o provimento de água, a proteção da biodiversidade, a beleza cênica e a manutenção de recursos genéticos (MINISTÉRIO DO MEIO AMBIENTE et al., 2017).

O Espírito Santo, por meio da Secretaria de Estado do Meio Ambiente e Recursos Hídricos - SEAMA, publicou a Portaria $n^{\circ}$ 005-R, de 22 de março de 2019, que instituiu a sua política de PSA (ESPÍRITO SANTO, 2019). Tal política é executada por meio do "Programa Reflorestar", que obedece a regras e funcionamento peculiar. O 
produtor rural que tiver interesse por tais recursos, desde que se enquadre nos critérios descritos no edital vigente, fará jus ao recebimento de recurso financeiro para apoiar a implantação ou manutenção em sua propriedade de uma ou mais modalidades de intervenção. O recurso financeiro pode ser do tipo PSA de Longo Prazo e, ou, PSA de Curto Prazo conforme descrito na Portaria $n^{\circ} 005-R$, de 22 de março de 2019 (ESPÍRITO SANTO, 2019).

Resumidamente, serão descritos os tipos de PSA aplicáveis e as modalidades apoiadas.

PSA de Longo Prazo: é classificado como o Pagamento por Serviços Ambientais concedidos em forma de compensação financeira ao proprietário rural ou outro facilitador para manutenção e recuperação dos serviços ambientais auferidos, sendo o recurso pago de uso livre e irrestrito do seu recebedor. Aplicável para as modalidades:

- Floresta em Pé (FPE);

- Restauração por meio do Plantio de Essências Nativas (REC); e

- Restauração por meio da Condução da Regeneração Natural (REG).

Dentro do "Programa Reflorestar" o PSA de longo prazo é pago em cinco parcelas anuais; ou seja, o contrato de PSA terá duração mínima de cinco anos para essas modalidades (ESPÍRITO SANTO, 2019).

PSA de Curto Prazo: é o Pagamento por Serviços Ambientais concedidos em forma de apoio financeiro ao proprietário rural ou outro facilitador para a aquisição dos insumos necessários à geração desses serviços. Aplicável para as modalidades:

- Restauração por meio do Plantio de Essências Nativas (REC);

- Restauração por meio da Condução da Regeneração Natural (REG);

- Sistemas Agroflorestais (SAF);

- Sistemas Silvipastoris (SSP); e

- Floresta Manejada (FM).

Dentro do "Programa Reflorestar" o PSA de curto prazo é pago em três parcelas anuais; ou seja, o contrato de PSA terá duração mínima de três anos para essas modalidades (ESPÍRITO SANTO, 2019).

O principal objetivo do "Programa Reflorestar" é o aumento da cobertura florestal do Estado do Espírito Santo, conciliando a conservação dos recursos naturais e a geração de renda ao produtor rural. Uma de suas metas estabelecidas é atingir 20 mil hectares de vegetação nativa recuperada até o final deste ano de 2020 (BENINI et al., 2018).

Apesar da política de PSA ter sido instituída no Espírito Santo desde 2012 e existir metas para a recuperação de vegetação nativa, não se encontra estudos referentes aos resultados alcançados. As informações divulgadas pelo governo do estado são geralmente superficiais, abordando somente o que foi projetado e não explora o que foi de fato executado, nem os parâmetros alcançados por cada modalidade (SOSSAI, 2019).

Portanto há uma carência na avaliação de parâmetros quantitativos e qualitativos do programa Reflorestar para a avaliação do sucesso ou não da sua estratégia. A análise do sucesso de políticas públicas é fundamental para evitar o desperdício de recursos 
públicos, geralmente escassos, em programas desconectados com as reais necessidades da população (FALCONI, 2009).

A cafeicultura pode reivindicar tal recurso. Será uma excelente oportunidade para o pequeno produtor familiar que realizou o CAR (Cadastro ambiental rural) e necessita realizar a adequação ambiental de sua propriedade, mas não possui recursos suficientes para a sua execução. Para aqueles que ainda não fizeram o CAR, a empresa que presta tal serviço de análise objetivando o enquadramento junto ao Programa, realiza essa tarefa, sem custos para o produtor rural. Infelizmente, há muita desinformação sobre o "Programa Reflorestar".

\section{Considerações finais}

Considerando que a degradação ambiental é cada vez mais comum nos dias atuais, o desenvolvimento técnico ou métodos de recuperação de áreas degradadas, de forma mais contínua, ajudará o ambiente uma vez degradado pelo homem a se recuperar.

Atualmente, os cafeicultores que fazem uso do sistema convencional entram em um sistema cíclico e vicioso. Tal sistema favorece a redução da biodiversidade e promove o empobrecimento dos solos, causando o aparecimento de pragas, doenças e ervas invasoras, fazendo com que o agricultor tenha que utilizar cada vez mais agroquímicos para conseguir produzir: além do custo ambiental, também o financeiro.

A perda de fertilidade do solo e sua compactação promovem a erosão e reduz a atividade biológica. Essa agricultura não é adequada para responder aos novos desafios da segurança alimentar e nutricional no Século 21 e nem à necessidade de uma produção sustentável, inclusiva e resiliente: tanto do ponto de vista socioambiental, como econômico/financeiro. A agricultura convencional não previne a degradação dos solos e promove a perda de biodiversidade: ambos são essenciais, especialmente para a sucessão e a sustentabilidade das futuras gerações.

$\mathrm{Na}$ medida em que o homem vai adquirindo consciência de que seus atos de conservação do solo são essenciais para os agrossistemas, passa a dar mais valor à natureza e sua biodiversidade, passa a ser o seu protetor, recuperando áreas degradadas. Atividades de recuperação e manejo por meio de práticas conservacionistas e agroecológicas garantirão qualidade às futuras gerações. Quando aplicadas à cultura cafeeira, é de extrema importância, visto que trata de uma cultura relativamente exigente em nutrição: dependente da situação na qual o solo se encontra.

Atualmente, diversos fatores vêm afetando a produção do café brasileiro, como a perda de preços, devido à maior competição mundial e à demanda por melhor qualidade, além de fatores ligados às barreiras não tarifárias, como aquelas relacionadas às questões ambientais. Para o sucesso futuro da atividade, tem-se mostrado fundamental às observações relacionadas às condições climáticas adversas, consequência do aquecimento global, bem como a adoção de práticas conservacionistas e de manejo adequado do solo.

Em anos recentes, o Instituto Federal do Espírito Santo (Ifes) - campus de Alegre e a Empresa Júnior de Cafeicultura (Caparaó Júnior), atendem a cafeicultores em um programa de extensão rural que é um caso de sucesso. O planejamento adotado prevê a aplicação de questionários com informações diversas que permitam estabelecimento de estratégias de intervenção pautada na construção coletiva, 
deixando de lado a ideia de que apenas os técnicos e especialistas devem participar das decisões: esse é um diferencial do programa.

Há de se considerar que o agricultor tem a capacidade de perceber o que está acontecendo à sua volta e entender, por meio do conhecimento adquirido ao longo de sua vivência com o agroecossistema, como os diversos ambientes dentro de sua propriedade funcionam e, com isso, planejar e gerenciar melhor. Atualmente, segundo o Prof. Pavesi e os estagiários do programa, a água tem sido tema recorrente das reuniões com os produtores rurais.

Dessa forma, por iniciativas como estas, e tantas outras de empresas como a brilhante e eficiente Incaper, tratando-se das atividades agrícolas, particularmente a cafeicultura, vem ganhando espaço crescente as iniciativas que buscam conciliar a produção agrícola com a conservação ambiental e os preceitos da segurança alimentar - é uma tendência mundial. Cabe lembrar que o café é exportado para países onde os consumidores são bastantes exigentes sob esses aspectos: sustentabilidade, rastreabilidade e qualidade.

Produtos orgânicos, agroecológicos, ambientalmente limpos e, ou, de alto valor biológico, são frutos da agricultura moderna e sustentável. Técnicas de recuperação, conservação e manejo da lavoura cafeeira serão fundamentais para garantir a sustentabilidade socioambiental e financeira da atividade cafeeira.

\section{Agradecimentos}

Ao IFES campus de Alegre, pela oportunidade de publicar sobre este tema de grande importância para a sociedade.

Ao professor Maurício Novaes Souza pelo conteúdo lecionado na disciplina de Recuperação de Áreas Degradadas pelo Programa de Mestrado Profissional em Agroecologia do Ifes campus de Alegre.

\section{Referências}

ALBUQUERQUE, P. E. P.; DURÃES, F. O. M. Uso e manejo de irrigação. Brasília, DF: Embrapa Informação Tecnológica, 2008. 508p.

ALVES, E. L.; PEREIRA, F. A. C.; DALCHIAVON, F. C. Potencial econômico da utilização de microterraceamento em lavouras de café: um estudo de caso. Revista iPecege, v. 3, n. 1, p. 24-38, 2017. https://doi.org/10.22167/r.ipecege.2017.1.24.

ANCAR (CEARÁ). Produtor de forragem. 1. ed. CEARÁ: Departamento de Documentação e Divulgação, 1974. 70 p. v. 1.

ANGELETTI, M da P. et al. Espécies vegetais para cobertura do solo: guia ilustrado. Vitória, ES: Incaper, $2018 . \quad 76 \quad$ p. https://doi.org/10.13140/RG.2.2.30123.95526.

ARF, O. et al. Efeito da rotação de culturas, adubação verde e nitrogenada sobre o rendimento do feijão. Revista Pesquisa Agropecuária Brasileira, Brasília, v.34, n.11, p.2029-2036, 1999. https://doi.org/10.1590/S0100-204X1999001100008. 
BENINI, R. M. et al. Plano estratégico da cadeia da restauração florestal no Espírito Santo. Espírito Santo, 2018. 29 p. Disponível em: <http://repositorio.ipea.gov.br/handle/11058/9228>. Acesso em: 10 jan. 2021.

BERNARDES, T. G. et al. Decomposição da biomassa e liberação de nutrientes dos capins braquiária e mombaça, em condições de cerrado. Pesquisa Agropecuária Tropical, Goiânia, v. 40, n. 3, p. 370-377, 2010. Disponível em: <https://www.revistas.ufg.br/pat/article/view/5584>. Acesso em: 10 jan. 2021.

BERTOLINI, D. et al . Manual técnico de manejo e conservação de solo e água: tecnologias disponíveis para controlar o escorrimento superficial do solo. Campinas: CATI, 1993. v. 4. p. 1-65 (CATI. Manual, 41).

BERTOLINI, D.; LOMBARDI NETO, F. Manual técnico de manejo e conservação de solo e água: embasamento técnico do Programa Estadual de Microbacias Hidrográficas. Campinas: CATI, 1994. v. 1. p. 1-15 (CATI. Manual, 38).

BORDIN, B. C. M. et al. Respostas produtivas de lavoura de primeira safra às colheitas manual e mecanizada. In: SIMPÓSIO DE PESQUISA DOS CAFÉS DO BRASIL, 10., 2019, Vitória. Anais... Vitória, 2019.

BRASIL. Ministério da Ciência, Tecnologia e Inovação. Segunda comunicação inicial do Brasil: parte II: Inventário de emissões e remoções antrópicas de gases de efeito estufa não controlados pelo Protocolo de Montreal. Brasília, DF, 2010. 102 p.

BRAUN, $\mathrm{H}$. et al. Produção de mudas de café 'conilon' propagadas vegetativamente em diferentes níveis de sombreamento. IDESIA. Chile. v. 25, n. 3, 2007. http://dx.doi.org/10.4067/S0718-34292007000300009.

BRSCAN, I. M. Animação mostra, passo a passo, como realizar um terraceamento com curva de nível. Brasília: Portal Embrapa, 19 abr. 2016. Disponível em: <https://www.embrapa.br/busca-de-noticias//noticia/11733925/animacao-mostra-passo-a-passo-como-realizar-um-terraceamentocom-curva-de-nivel>. Acesso em: 07 out. 2019.

CAFEPOINT. Campeão do Cup of Excellence busca incentivar jovens cafeicultores da região. Disponível em: <https://www.cafepoint.com.br/noticias/girode-noticias/campeao-do-cup-of-excellence-busca-incentivar-jovens-cafeicultores-daregiao-223175/>. Acesso em: $11 \mathrm{dez} .2020$.

CARDOSO, R. A. et al. Influência da adubação verde nas propriedades físicas e biológicas do solo e na produtividade da cultura de soja. Semina: Ciências Biológicas e da Saúde, Londrina, v. 35, n. 2, p. 51-60, 2014. http://dx.doi.org/10.5433/1679-0367.2014v35n2p51.

CARVALHO, A. M. et al. Manejo de plantas de cobertura na floração e na maturação fisiológica e seu efeito na produtividade do milho. Pesquisa Agropecuária Brasileira, v. 50, n. 7, p. 551-561, 2015. https://doi.org/10.1590/S0100-204X2015000700005.

CEDAGRO, CENTRO DE DESENVOLVIMENTO O AGRONEGÓCIO, Levantamento de áreas agrícolas degradadas no estado do Espírito Santo. Documento de trabalho, Vitória: $2012 . \quad$ SEAG, Disponível em: 
<http://www.cedagro.org.br/artigos/20121101104240_areas_Degradadas_Documento _Completo.pdf>. Acesso em: 29 out. 2020.

CEDAGRO. Centro de Desenvolvimento do Agronegócio. Levantamento de áreas agrícolas degradadas no estado do espírito santo. Documento completo. Vitória ES, $2012 . \quad$ Disponível em: <http://www.cedagro.org.br/artigos/20121101104240_areas_Degradadas_Documento _Com pleto.pdf>. Acesso em: 16 nov. 2020.

CNA - COMPANHIA NACIONAL DE ABASTECIMENTO (CONAB). 2018. Acompanhamento da Safra Brasileira - Café. v. 5, safra 2018, N.2- Segundo levantamento. Disponível em: <https://pt.slideshare.net/luizvaleriano/ acompanhamento-da-safra-brasileira-de-caf-2-levantamento-maio-2018>. Acesso em: 16 jul. 2020.

CONCEIÇÃO, M. A. F. Critérios para instalação de quebra-ventos. Comunicado Técnico, Jales, SP, 1996. p 1-2.

DONAGEMA, G. K. Manual de métodos de análise de solos. Embrapa Solos. Rio de Janeiro, 2011. 230 p. - (Documentos / Embrapa Solos, ISSN 1517-2627; 132). Disponível em: <https://www.embrapa.br/busca-de-publicacoes/-/publicacao/ 990374/manual-de-metodos-de-analise-de-solo>. Acesso em: 23 nov. 2019.

EIRAS, P. P.; COELHO, F. C. Utilização de leguminosas na adubação verde para a cultura de milho. Revista científica internacional, ano 4, n. 17, p. 96-124, 2011. Disponível em: <https://www.semanticscholar.org/paper/UTILIZA\%C3\%87\%C3\%830DE-LEGUMINOSAS-NA-ADUBA\%C3\%87\%C3\%830-VERDE-PARA-A-Eiras-

Coelho/bfc6328aa7da6e77069f4db006af74799f12ee6d>. Acesso em: 10 jan. 2021.

EMBRAPA ACRE. Rio Branco: Embrapa Acre, 2004. 44 p. il. color. (Embrapa acre. Documentos, 85). Disponível em: $<$ http://ainfo.cnptia.embrapa.br/digital/bitstream/CPAFAC/10514/1/doc85.pdf>. Acesso em: 07 out. 2019.

EMBRAPA. Adubação verde. Seropédica. Embrapa Agrobiologia. 2011.

EMBRAPA. Espaçamentos e terraços. PROGRAMA RIO RURAL: SECRETARIA DE AGRICULTURA, PECUÁRIA, PESCA E ABASTECIMENTO / SUPERINTENDÊNCIA DE DESENVOLVIMENTO SUSTENTÁVEL. 2018. 46 p.

EPAGRI. Terraceamento reduz erosão e efeitos da estiagem no Oeste Catarinense. Disponível em: <https://www.noticiasagricolas.com.br/noticias/meioambiente/261852-terraceamento-reduz-erosao-e-efeitos-da-estiagem-no-oestecatarinense.html>. Acesso em: 12 dez. 2020.

ESPÍRITO SANTO. Portaria $\mathrm{n}^{\circ}$ 005-R, de 22 de março de 2019. Torna Público o Edital de Convocação de Produtores Rurais que Desejam Participar do Ciclo 2019 do Programa Reflorestar. Diário Oficial dos Poderes do Estado, Vitória, ES, 01 de abril de 2019, p. 176- 181.

EUTRÓPIO, F. J.; KROHLING, C. A. Fertilidade do solo em lavouras de café arábica com e sem terraço. In: CONGRESSO BRASILEIRO DE PESQUISAS CAFEEIRAS, 44., 2018. Anais... Franca, SP: CBPC, 2018. 
FALCONI, V. C. O Verdadeiro Poder. $2^{\mathrm{a}}$ Edição. Nova Lima, MG: Falconi Consultores de Resultado, 2009. ESPÍRITO SANTO. Decreto $\mathrm{n}^{\circ}$ 3182-R, de 20 de dezembro de 2012. Aprova o regulamento da Lei 9.864/2012, que dispõe sobre o Programa de Pagamento por Serviços Ambientais - PSA. Diário Oficial dos Poderes do Estado, Vitória, ES, 21 de dezembro de 2012, p. 26-27.

FERNANDES, M. F.; BARRETO A.C.; EMÍDIO FILHO J. Fitomassa de adubos verdes e controle de planta daninhas em diferentes densidades populacionais de leguminosas. Pesquisa Agropecuária Brasileira. Brasília, v.34, n.9, p.1593-1600, 1999. https://doi.org/10.1590/S0100-204X1999000900009.

FERRÃO, R. G. et al. Café conilon: técnicas de produção com variedades melhoradas. 4. ed. revisada e ampliada. Vitória, ES: Incaper, 2012. (Incaper: Circular Técnica, 03-I) 74 p. Disponível em: $<$ https://biblioteca.incaper.es.gov.br/digital/bitstream/item/1080/1/Circular-TecnicaConilon-03I-4Edicao-espanhol-VF.pdf>. Acesso em: 10 jan. 2021.

FERRARI NETO, J. et al. Consórcio de guandu-anão com milheto: persistência e liberação de macronutrientes e silício da fitomassa. Bragantia, Campinas, v. 71, n. 2, p. 264-272, 2012. https://doi.org/10.1590/S0006-87052012005000017.

FRANÇA, F. M. C.; OLIVEIRA, J. B. Quebra-ventos na propriedade agrícola. Cartilhas temáticas - tecnologias e práticas hidroambientais para convivência com 0 Semi-árido, Fortaleza, CE, 2010, 21p.

FRANCO, C. M. et al. Manutenção de cafezal com adubação exclusivamente mineral. Bragantia, Campinas, v.19, n.33, p.523-546, 1960. https://doi.org/10.1590/S000687051960000100033.

FRANCO, C. M.; LAZZARINI, W. Ensaio de adubação mineral NPK e adubos verdes. In: LAZZARINI et al. Experimentação cafeeira, 1929-1963. Campinas: Secretaria da Agricultura do Estado de São Paulo - Instituto Agronômico, 1967. p.173

FRANCO, F. S. Sistemas agroflorestais: uma contribuição para a conservação dos recursos naturais na Zona da Mata de Minas Gerais. 2000. 128f. Tese (Doutorado em Ciência Florestal) - Universidade Federal de Viçosa, Viçosa, MG, 2000.

GALEANO, E. V.; KROHLING, C. A. Avaliação de custo de produção e viabilidade econômica do café arábica no Espírito Santo considerando colheita manual e semimecanizada. In: CONGRESSO DA SOCIEDADE BRASILEIRA DE ECONOMIA, ADMINISTRAÇÃO E SOCIOLOGIA RURAL, 56., 2018, Campinas. Anais... Campinas, SP: SOBER, 2018.

GALETI, P. A. Práticas de controle à erosão. Campinas: Instituto Campineiro de Ensino Agrícola, 1984. 154p.

GRIEBELER, N. P. et al. Modelo para o dimensionamento e a locação de sistemas de terraceamento em nível. Eng. Agríc., Jaboticabal, v. 25, n. 3, p. 696-704, Dec. 2005. http://dx.doi.org/10.1590/S0100-69162005000300015.

INCAPER - INSTITUTO CAPIXABA DE PESQUISA, ASSISTÊNCIA TÉCNICA E EXTENSSÃO RURAL, Cafeicultura. Vitória, INCAPER, 2020. Disponível em: < https://incaper.es.gov.br/cafeicultura>. Acesso em: 27 out. 2020. 
KROHLING, C. A. et al. Colheita semimecanizada de café arábica na Região das Montanhas Capixaba. In: CONGRESSO BRASILEIRO DE PESQUISAS CAFEEIRAS, 44., 2018, Franca. Anais... Franca, SP: CBPC, 2018.

KROHLING, C. A.; SOBREIRA, F. M. Tipos de podas e produtividade da lavoura microterraceada de café arábica. In: CONGRESSO BRASILEIRO DE PESQUISAS CAFEEIRAS, 44., 2018, Franca. Anais... Franca, SP: CBPC, 2018.

LAZZARINI, W.; NEME, A. N. Ensaio de adubação verde e química. In: LAZZARINI et al. Experimentação cafeeira, 1929-1963. Campinas: Secretaria da Agricultura do Estado de São Paulo - Instituto Agronômico, 1967. p. 199-203.

LEAL, J. T. da C. P.; FERNANDES, M. R.; PEREIRA, R. T. G. Boas práticas ambientais na cafeicultura. Belo Horizonte: EMATER-MG, 2012. 64 p.

LEITE, L. F. C. et al. 2010. Decomposição e liberação de nutrientes de resíduos vegetais depositados sobre Latossolo Amarelo no cerrado maranhense. Revista Ciência Agronômica, Fortaleza, v. 41, n. 1, p. 29-35, 2010. https://doi.org/10.5935/1806-6690.20100004.

LOMBARDI-NETO, F. et al. Efeito de algumas práticas conservacionistas vegetativas na produção de café. In: CONGRESSO BRASILEIRO DE CIÊNCIA DO SOLO, 15., 1975, Campinas. Anais... Campinas: Sociedade Brasileira de Ciência do Solo, 1976. p.547-550.

LOPES, O. M. N. Feijão-de-porco: leguminosa para controle de mato e adubação verde do solo. EMBRAPA AMAZÔNIA ORIENTAL: Altamira, PA. RECOMENDAÇÕES TÉCNICAS N 12/2000. 4p.

LOPES, P. R. al. Produção de café agroecológico no sul de Minas Gerais: sistemas alternativos à produção intensiva em agroquímicos. Revista Brasileira de Agroecologia, [S.I.], v. 7, n. 1, mar. 2012. Disponível em: <http://revistas.abaagroecologia.org.br/index.php/rbagroecologia/article/ view/9979>. Acesso em: 27 jul. 2020.

MACAULAY LAND USE RESEARCH INSTITUTE; UK AGROFORESTRY FORUM. Silvopastoral Agroforestry Toolbox. [Web Page]. Disponível em: <https://www.agroforestry.com.br>. Acesso em: 27 out. 2020.

MAGALHÃES, G. M. F. Análise da eficiência de terraços de retenção em sub-bacias hidrográficas do Rio São Francisco. Revista brasileira de engenharia agrícola e ambiental, v. 7, n. 10, p. 1109-1115, 2013. https://doi.org/10.1590/S141543662013001000013.

MARTINS, C. R. et al. Leguminosas na fruticultura: uso e integração em propriedades familiares do sul do Brasil - Brasília, DF: Embrapa, p. 66, 2019.

MARTINS, M. C.; SOUZA, M. N. Uma análise das variáveis do desenvolvimento rural sustentável no uso da Integração Lavoura Pecuária e Floresta (ILPF) em municípios da Zona da Mata de Minas Gerais. Multifuncionalidades sustentáveis no campo: Agricultura, pecuária e florestas, v.5, p.10-15, 2013. Disponível em: <https://www.locus.ufv.br/handle/123456789/4170>. Acesso em: 10 jan. 2021. 
MATIELLO, J. B. Sistemas de Produção na Cafeicultura Moderna, Tecnologias de Plantio adensado, renque mecanizado, arborização e recuperação de cafezais. 1 ed.. Rio de Janeiro: MM Produções Gráficas 1995. 102p.

MATIELLO, J. B. Tecnologia de microterraceamento em cafezais evolui bastante. Disponível em: Procafé: <https://www.noticiasagricolas.com.br>. Acesso em: $11 \mathrm{dez}$. 2020.

MATIELLO, J. B. et al. Cultura do café no Brasil: manual de recomendações. Rio de Janeiro, RJ e Varginha, MG: Mapa/Procafé, 2016, 584 p.

MELLES, C. C. A. et al. Efeito de culturas intercalares na cultura do cafeeiro. In: CONGRESSO BRASILEIRO DE PESQUISAS CAFEEIRAS, 7., 1979, Araxá. Resumos... Rio de Janeiro: IBC/GERCA, 1979. p. 174-175.

MELO, V. F. et al. Chemical and biological quality of the soil in different systems of use in the savanna environment. Revista Agro@mbiente on-line, v.11, n. 2, p.101-110, 2017. Disponível em: <https://revista.ufrr.br/agroambiente/issue/view/225>. Acesso em: 10 jan. 2021.

MESQUITA, C. M. de et al. Manual do café: implantação de cafezais Coffea arabica L. Belo Horizonte: EMATER-MG, 2016. 50 p.

MIRANDA, S. C. et al. Apontamentos sobre mudanças climáticas na agricultura Brasileira. Revista Enciclopédia Biosfera, v. 15, n. 27, p. 95-106, 2018. https://doi.org/10.18677/EnciBio_2018A9.

OLIVEIRA, C. D. de. Quebra-vento em lavouras de café. Revista Cafeicultura. 2009. Disponível em: <https://revistacafeicultura.com.br/?mat=20151>. Acesso em: 08 nov. 2019.

PELISSARI, S. A.; PERINI, J. L.; MIRANDA, M. A. Caixas coletoras de água das chuvas. Jornal da Cooabriel, São Gabriel da Palha, ES: Ano XI, n. 115, p. 8, 1997.

PEREIRA, A. P. et al. Ciclagem de nutrientes por plantas de cobertura de verão. Rev. $\begin{array}{llllllll}\text { de Ciências Agrárias, } & \text { v. 40, } & \text { n. } 4, \quad \text { p. 799-807, }\end{array}$ http://dx.doi.org/10.19084/RCA17065.

PIRES, F. R.; SOUZA, C. M. Práticas mecânicas de conservação do solo e da água, 1999.

PRIMAVESI, A. Manejo ecológico do solo. 18 ed. São Paulo: Nobel, 2006.

PRUSKI, F. F. Conservação do solo e água: práticas mecânicas para o controle da erosão hídrica. Viçosa: ED. UFV, 2009. 279p.

PRUSKI, F.F.; GRIEBELER, N.P. Comparação entre métodos para a determinação do volume de escoamento superficial. In: Congresso Brasileiro de Engenharia Agrícola, 25 e Congresso Latino-Americano de Engenharia Agrícola, 2, 1996, Bauru. Anais... Bauru: Sociedade Brasileira de Engenharia Agrícola, 1996. 422 p.

RAMOS, G. M. Recomendações práticas para o cultivo do guandu para produção de feno. Teresina: EMBRAPA-CPAMN. 1994. 16 p. (EMBRAPA-CPAMN. Circular Técnica, 13). 
REIS, A. J.; ARRUDA, H. V. Alguns resultados sobre técnicas culturais do cafeeiro na região de Ribeirão Preto. In: CONGRESSO BRASILEIRO DE PESQUISAS CAFEEIRAS, 2., 1974, Poços de Caldas. Resumos... Rio de Janeiro: IBC, 1974. p.324-326

REIS, A. J.; ARRUDA, H. V. Efeito depressivo da soja perene como adubo verde para cafezal. In: CONGRESSO BRASILEIRO DE PESQUISAS CAFEEIRAS, 8., 1980, Campos do Jordão. Anais... IBC-GERCA. p.101-103

RESCK, D. V. S. A conservação da água via terraceamento em sistemas de plantio direto e convencional no cerrado. Planaltina: Embrapa Cerrados, 2002. 8p (Embrapa Cerrados. Circular técnica, 22). Disponível em: < https://www.infoteca.cnptia.embrapa.br/handle/doc/559652>. Acesso em: 07 out. 2019.

SALEMI, L.F. Plantio em nível: a medida básica de conservação do solo, 2009. Disponível em: <http://www.webartigos.com>. Acesso em: 10 out. 2019.

SALGADO, B. G. et al. Avaliação da fertilidade dos solos de sistemas agroflorestais com cafeeiro (coffea arabica I.) em Lavras-MG. Revista Árvore, Viçosa, v.30, n.3, p. 343 - 349, 2006. https://doi.org/10.1590/S0100-67622006000300004.

SANTILLI, J.; BUSTAMANTE, P. G.; BARBIERI, R. L. (editoras técnicas). Agrobiodiversidade. Coleção Transição Agroecológica, v. 2. Brasília, DF: Embrapa, 2015. 308 p.

SEAG. Secretaria de Estado da Agricultura, Abastecimento, Aquicultura e Pesca. Plano Estratégico de Desenvolvimento da Agricultura Capixaba: novo PEDEAG 2007- 2025/ Secretaria de Estado da Agricultura, Abastecimento, Aquicultura e Pesca - Vitória: SEAG, p. 284. 2008.

SECRETARIA de Estado de Minas Gerais. Mais de dez cidades do Centro-Oeste de MG devem ter nascentes do Rio São Francisco revitalizadas até 2020 | CentroOeste | G1 (globo.com). Disponível em: <https://g1.globo.com>. Acesso em: 20 set. 2020.

SILVA, M. R. da Construção dos terraços com terraceadores. Revista Cultivar, v. 34, n. 164, p. 34-39, 2019. Disponível em: $<$ https://www.grupocultivar.com.br/artigos/construcao-dos-terracos-comterraceadores>. Acesso em: 10 jan. 2021.

SILVEIRA, A. de S. et al. 'Sensory analysis of specialty coffee from different environmental conditions in the region of Matas de Minas, Minas Gerais, Brazil. Rev. Ceres, Viçosa , v. 63, n. 4, p. 436-443, Aug. 2016. Disponível em: http://dx.doi.org/10.1590/0034-737X201663040002. Acesso em: 12 dez. 2020.

SOSSAI, M. F. A floresta como fonte de biodiversidade e de renda para o produtor rural. Vitória, 20 de outubro de 2019. Disponível em: <https://docplayer.com.br/33601815-Governodo-estado-do-espirito-santo-secretariaestadual-de-meio-ambiente-e-recursos-hidricos.html>. Acesso em: 15 out. 2020.

SOUSA, I. R. L de et al. Decomposição de espécies utilizadas como adubação verde em sistema agroflorestal experimental, Santarém, Pará. Agroecossistemas, v. 10, n. 2, p. $50-63,2018$. 
SOUZA JUNIOR, W. D.; BALDISSERA, J. F.; BERTOLINI, G. R. F. Análise de opções reais aplicada na diversificação da produção rural no estado do Paraná. Rev. Econ. Sociol. Rural, Brasília, v. 57, n. 2, p. 253- 269, 2019 . Disponível em: http://dx.doi.org/10.1590/1806-9479.2019.177157.

SOUZA, I. I. de M. et al. Effect of Afforestation of Arabica Coffee on the Physical and Sensorial Quality of the Bean. Journal of Experimental Agriculture International, v. 42, n. 7, p. 133-143, 2020.

SOUZA, M. N. Degradação Antrópica e Procedimentos de Recuperação Ambiental. Balti, Moldova, Europe: Novas Edições Acadêmicas, 2018, v.1000. 376p.

SOUZA, M. N. Mudanças no uso do solo e da água e a gestão dos recursos naturais. Frankfurt, Alemanha: Novas Edições Acadêmicas, 2015, v.5000. 376p.

TEIXEIRA, M. B. et al. Decomposição e ciclagem de nutrientes dos resíduos de quatro plantas de cobertura do solo. Idesia, v. 30, n. 1, p. 55-64, 2012. http://dx.doi.org/10.4067/S0718-34292012000100007.

TEODORO, R. B. et al. Aspectos agronômicos de leguminosas para adubação verde no Cerrado no Alto Vale do Jequitinhonha. Revista Brasileira de Ciência do Solo, v. 35, p. 635-643, 2011. https://doi.org/10.1590/S0100-06832011000200032.

THOMAZIELLO, R. A.; PEREIRA, S. P. Poda e condução do cafeeiro arábica. Boletim técnico IAC 203 Campinas, São Paulo: Instituto Agronômico de Campinas [IAC], 2008.

TORRES, C. M. M. E. et al. Sistemas agroflorestais no Brasil: uma abordagem sobre a estocagem de carbono. Pesquisa Florestal Brasileira. Colombo, v. 34, n. 79, p. 235244, 2014. https://doi.org/10.4336/2014.pfb.34.79.633.

TORRES, J. L. R. et al. Production, decomposition of residues and yield of maize and soybeans grown on cover crops. Revista Ciência Agronômica, v. 46, n. 3, p. 460468, 2015. http://dx.doi.org/10.5935/1806-6690.20150026.

TRISTÃO, F. A. et al. Tendências para a sustentabilidade da cafeicultura de arábica em regiões de montanha. Incaper em Revista, Vitória, v. 10, p. 105-124, jan./dez., 2019.

VENTURA, J. A et al. Diagnóstico e manejo das doenças do cafeeiro conilon. In: FERRÃO, R. G. et al. (Eds). Café conilon. Vitória, ES: Incaper, 450-497. 2007.

VITAL, A. R. T. et al. Produção de serapilheira e ciclagem de nutrientes de uma floresta estacional semidecidual em zona ripária. Revista Árvore, v. 28, n. 6, p.793800, 2004. http://dx.doi.org/10.1590/S0100-67622004000600004.

WADT, P. G. S. Construção de terraços para controle da erosão pluvial no estado do Acre. Rio Branco: Embrapa Acre, 2004. 44 p. il. color. (Embrapa acre. Documentos, 85). Disponível em: <https://www.infoteca.cnptia.embrapa.br/ handle/doc/501671>. Acesso em: 07 out. 2019.

$\mathrm{XIAO}, \mathrm{H}$. et al. Soil erosion-related dynamics of soil bacterial communities and microbial respiration. Applied Soil Ecology, v. 119, p. 205-213, 2017. http://dx.doi.org/10.1016/j.apsoil.2017.06.018.

ZACARIAS, A. J. et al. Efeito de adubos verdes em consórcio com cafeeiro e sua 
viabilidade econômica. Resumos.... I Encontro Anual de Agroecologia e Qualidade de Vida do Ifes campus de Alegre. Pôster e apresentação oral. 2019.

ZACARIAS, A. J.; SOUZA, M. N. Recuperação de área degradada de monocultura intensiva no estado do Espírito Santo. REVISTA DA UNIVAP, v.1, n. 87, p.234-242, 2019 .

\section{Autores}

Cleber Cássio Ferreira ${ }^{1}$, Mário Euclides Pechara da Costa Jaeggi ${ }^{2}$, Thiago Blunck Rezende Moreira ${ }^{1}$, Maurício Novaes Souza ${ }^{1 *}$, Dayvson Dandi Rodrigues ${ }^{1}$, Ronald Assis Fonseca ${ }^{1}$, Fábio Gomes Zampieri ${ }^{1}$, Credigar Gonçalves Moreira ${ }^{1}$, Alex Justino Zacarias $^{1}$, Isabel Inácio de Moraes Souza ${ }^{1}$

1. Programa de Pós-Graduação em Agroecologia, Instituto Federal do Espírito Santo Campus de Alegre. Caixa Postal 47, CEP: 29500- 000, Alegre-ES.

2. Universidade Estadual Norte Fluminense Darcy Ribeiro, CEP: 28013-600, Campos dos Goytacazes-RJ.

*Autor para correspondência: mauricios.novaes@ifes.edu.br 